CAMILA BILLERBECK

REGRAS OPERATIVAS E ANÁLISE DE DESEMPENHO DE SISTEMAS DE RESERVATÓRIOS OBTIDAS POR MODELOS DE PROGRAMAÇÃO DINÂMICA, REDES NEURAIS E SIMULAÇÃO EM REDE DE FLUXO 



\section{CAMILA BILLERBECK}

Regras operativas e análise de desempenho de sistemas de reservatórios obtidas por modelos de programação dinâmica, redes neurais e simulação em rede de fluxo

Dissertação apresentada a Escola Politécnica da Universidade de São Paulo para obtenção do título de Mestre em Ciências.

Área de Concentração:

Engenharia Hidráulica e Ambiental

Orientador:

Prof. Dr. Arisvaldo Vieira Méllo Junior.

São Paulo 
Autorizo a reprodução e divulgação total ou parcial deste trabalho, por qualquer meio convencional ou eletrônico, para fins de estudo e pesquisa, desde que citada a fonte.

Este exemplar foi revisado e corrigido em relação à versão original, sob responsabilidade única do autor e com a anuência de seu orientador.

São Paulo, 27 de Setembro de 2018

Assinatura do autor: Camila Billerteds

Assinatura do orientador: Mrivnilloga.

\section{Catalogação-na-publicação}

\section{BILLERBECK, CAMILA}

Regras operativas e análise de desempenho de sistemas de reservatórios obtidas por modelos de Programação Dinâmica, Redes Neurais e simulação em rede de fluxo / C. BILLERBECK -- versão corr. -- São Paulo, 2018. $100 \mathrm{p}$.

Dissertação (Mestrado) - Escola Politécnica da Universidade de São Paulo. Departamento de Engenharia de Hidráulica e Ambiental.

1.Modelagem de recursos hídricos 2.Otimização 3.Operação de reservatório I.Universidade de São Paulo. Escola Politécnica. Departamento de Engenharia de Hidráulica e Ambiental II.t. 


\section{Agradecimentos}

Durante este trabalho tive a colaboração e o apoio de inúmeras pessoas. De certa maneira cada uma delas contribuiu para que eu pudesse chegar até o final.

Agradeço a Deus pela oportunidade, e aos meus pais Eliane e Marco pelo apoio incondicional.

Não poderia deixar de agradecer especialmente ao meu orientador e amigo, professor Arisvaldo Vieira Méllo Junior, pela confiança, apoio e paciência incansáveis, que me inspiraram tantas vezes ao longo desta jornada.

Agradeço à Wandréa, secretária da pós-graduação, pela solicitude e ajuda em todos os momentos de ansiedade.

Ao Laboratório de Sistemas de Suporte a Decisões (LabSid) e aos professores do Departamento de Engenharia Hidráulica e Ambiental, cujos ensinamentos foram essenciais para minha formação acadêmica.

Aos amigos queridos da "salinha" pela amizade sincera, e por compartilharem comigo as alegrias e desafios deste caminho tão particular, de quem escolheu se dedicar à pesquisa.

E aos amigos queridos do Batuíra, onde encontrei minha segunda casa, por todo o carinho que recebi nos últimos anos. 

"o real não está na saída nem na chegada: ele se dispõe para a gente é no meio da travessia"

Guimarães Rosa 


\section{RESUMO}

A metodologia apresentada neste trabalho contempla os aspectos relevantes para o desenvolvimento de modelos de otimização e de simulação combinados visando a análise de sistemas de reservatórios, e de regras operativas. Foram propostas quatro regras operativas para o Sistema Cantareira (SC), baseadas em uma série de afluências críticas $(2003$ - 2017). O trabalho foi desenvolvido em três etapas. Na primeira etapa foi utilizado um modelo de programação dinâmica (PD) para otimizar o comportamento do SC com relação ao atendimento das principais demandas. Na segunda etapa duas redes neurais artificiais (RNA) foram utilizadas para se obter as regras operativas para o $\mathrm{SC}$, a partir dos resultados da primeira etapa. O modelo de PD foi calculado com o software CSUDP, e a RNA foi formulada e calculada com o solver padrão do Microsoft Excel. As regras obtidas foram baseadas em estados, ou faixas, de armazenamento do reservatório. Na terceira etapa, as regras operativas foram simuladas para a série histórica do SC, de 1930 a 2017, com auxílio do modelo de rede de fluxo AcquaNet. O trabalho fornece subsídios para aplicações de modelos de otimização e para obtenção de políticas de operação em sistemas de reservatórios. A comparação das regras operativas fornece informações relevantes a respeito dos impactos dos estados de armazenamento considerados e dos valores requeridos para as demandas, na operação do reservatório ao longo da série. A Regra operativa 1 destaca-se por seu desempenho, fornecendo vazões de 33 $\mathrm{m}^{3} / \mathrm{s}$ com $80 \%$ de garantia para a região metropolitana de São Paulo (RMSP), e com menores falhas no atendimento às demandas durante para a série histórica.

Palavras-chave: Sistema de suporte a decisão, Sistema Cantareira, Otimização de reservatórios, AcquaNet. 


\begin{abstract}
The present work provides guidelines for application of optimization and simulation models combined, in reservoir system and reservoir operation analysis. Four operation rules based on a series of critical inflows $(2003-2017)$, are proposed for the Cantareira System (CS). The study was developed in three stages. In the first stage, a dynamic programming model (DP) was used to optimize the reservoir releases to the main demands. In the second stage, two artificial neural networks (ANR) were used to obtain the operation rules for SC, based on the results of the first stage. The DP model was solved using CSUDP software, and the ANR model was built and solved using Microsoft Excel. The operation rules were based on the reservoir's storage states or ranges. In the third stage, the operation rules were simulated for the system's historical inflow series, from 1930 to 2017, using the simulation net-flux model AcquaNet. In the last stage, reservoir operation rules were tested for the Cantareira system's historical inflow series, from 1930 to 2017, using the simulation net-flux model AcquaNet. The methodology provides relevant information for the analysis of optimization models and for operation rules in reservoir systems. The comparison of the proposed operation rules provides relevant information on the impacts of volume ranges, and of demand requirement values on long-term reservoir operation. The operation policy 1 shows best performance, providing supply of $33 \mathrm{~m} 3 / \mathrm{s}$ to Metropolitan Region of São Paulo (MRSP) during $80 \%$ of the period, and with less failures during the historical series.
\end{abstract}

Keywords: Decision support system, Cantareira system, Reservoir optimization, AcquaNet. 


\section{LISTA DE FIGURAS}

Figura 3.1 - Representação esquemática da abordagem de modelos implicitamente e explicitamente estocásticos aplicados à operação de reservatórios. Fonte:

LABADIE, 2004.

Figura 3.2- Esquema de operação de reservatório representada como um processo

de decisão sequencial ou em estágios. Fonte: LABADIE, 2004.

Figura 3.3 - Construção do corredor para iterações do algoritmo IDP, Fonte:

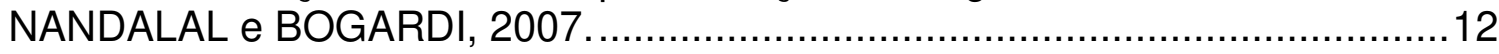

Figura 3.4 - Interface do programa CSUDP. …………..................................16

Figura 3.5 - CSUDP: Tela para configuração dos limites de restrição das variáveis.

Figura 3.6 - Interface do SSD AcquaNet

Figura 3.7 - Rede neural artificial progressiva em múltiplas camadas. Fonte:

Adaptado de HAYKIN, 2008

Figura 4.1 - Localização do Sistema Cantareira.

Figura 4.2 - Representação esquemática do Sistema Cantareira. Fonte: Adaptado de ANA (2014).

Figura 4.3 - Vazões afluentes médias ao RE do SC nos períodos de 1930 a 2015, 1953 a 1954 e de 2013 a 2014. Fonte: Adaptado de ANA (2014).

Figura 5.1 - Fluxograma da metodologia apresentada.

Figura 5.2 - Rede de fluxo do SC com reservatório equivalente.

Figura 5.3 - Vazões médias mensais afluentes ao reservatório equivalente do SC de janeiro/2003 a dezembro/2017.

Figura 5.4 - Vazões médias mensais afluentes a Buenópolis e Valinhos de janeiro/2003 a dezembro/2017.

Figura 5.5 - Exemplos de resultados de volumes finais armazenados no RE, obtidos com simulações do AcquaNet, alterando-se apenas a política de prioridades (PP).

Figura 5.6 - Rede de fluxo do SC.

Figura 5.7 - Fluxograma de simulações preliminares para obtenção conjunto de dados de treinamento da Rede $\mathrm{A}$, de acordo com configurações de regra operativa pré-definidas.

Figura 5.8 - Tipologia da Rede A. 
Figura 5.9 - Fluxograma da obtenção das demandas requeridas por faixa de operação, com auxílio da Rede B.

Figura 5.10 - Tipologia da Rede B.

Figura 5.11 - Vazões médias mensais afluentes ao reservatório equivalente do SC de janeiro/1930 a dezembro/2017.

Figura 5.12 - Vazões médias mensais afluentes a Buenópolis e Valinhos de janeiro/1930 a dezembro/2017.

Figura 6.1 - Volumes finais de armazenamento do RE e respectiva permanência, obtidos pela PD durante os anos de 2003 a 2017.

Figura 6.2 - Vazões fornecidas pelo RE às demandas RMSP, Buenópolis e Valinhos, e respectivas permanência, obtidas pela PD durante os anos de 2003 a 2017.

Figura 6.3 - Exemplo de estapas de cálculo da Rede A para um conjunto de dados de entrada.

Figura 6.4 - Exemplo de estapas de cálculo da Rede B para um conjunto de dados de entrada.

Figura 6.5 - Exemplo de saída da Rede B: Vazões fornecidas para a RMSP comparadas aos respectivos resultados da PD.

Figura 6.6 - Garantias de atendimento à RMSP da Regra 1, por faixa de operação, obtida por meio da Rede B

Figura 6.7 - Garantias de atendimento à Valinhos da Regra 1, por faixa de operação, obtida por meio da Rede B.

Figura 6.8 - Regra 1: volumes finais armazenados no RE e sua permanência. 65

Figura 6.9 - Regra 1: Fornecimento de vazões às demandas da RMSP, de Buenópolis e Valinhos.

Figura 6.10 - Regra 2: volumes finais armazenados no RE e sua permanência......67

Figura 6.11 - Regra 2: Fornecimento de vazões às demandas da RMSP, de Buenópolis e Valinhos.

Figura 6.12 - Regra 3: volumes finais armazenados no RE e sua permanência......69

Figura 6.13 - Regra 3: Fornecimento de vazões às demandas da RMSP, de Buenópolis e Valinhos. .70

Figura 6.14 - Regra 4: volumes finais armazenados no RE e sua permanência......71

Figura 6.15 - Regra 4: Fornecimento de vazões às demandas da RMSP, de Buenópolis e Valinhos. 
Figura 6.16 - Regra 4: volumes finais armazenados no RE e sua permanência......73

Figura 6.17 - Regra 4: Fornecimento de vazões às demandas da RMSP, de Buenópolis e Valinhos.

Figura 6.18 - Comparação das curvas de permanência dos volume finais armazenados pelo RE pelas regras operativas. 


\section{LISTA DE TABELAS}

Tabela 4.1 - Sistemas produtores da RMSP.

Tabela 4.2 - Resumo das características dos reservatórios do Sistema Cantareira. 28

Tabela 4.3 - Resumo das características dos túneis e canais do Sistema Cantareira.

Tabela 4.4 - Resumo da regra operativa vigente do Sistema Cantareira.

Tabela 5.1 - Volumes do reservatório equivalente e limites das restrições adotadas no modelo.

Tabela 5.2 - Configurações de faixas de operação pré-definidas, em termos da porcentagem de volume útil.

Tabela 5.3 - Características das simulações preliminares do modelo AcquaNet para as configurações de faixa de operação apresentadas.

Tabela 5.4 - Parâmetros de entrada e saída da Rede A.

Tabela 5.5 - Parâmetros de entrada e saída da Rede B. .......................................50

Tabela 5.6 - Características das simulações do modelo AcquaNet na Etapa 3. ......52

Tabela 6.1 - Regra 1 - Políticas de prioridades utilizadas para as pré-simulações do AcquaNet.

Tabela 6.2 - Regra 2 - Políticas de prioridades utilizadas para as pré-simulações do AcquaNet.

Tabela 6.3 - Regra 3 - Políticas de prioridades utilizadas para as pré-simulações do AcquaNet.

Tabela 6.4 - Regra 4 - Políticas de prioridades utilizadas para as pré-simulações do AcquaNet.

Tabela 6.5 - Soma quadrática das diferenças (Sq), correlação $(r)$, raiz do erro quadrático médio (RMSE) e coeficiente de eficiência de Nash-Sutcliffe, entre as prioridades utilizadas nas simulações preliminares (AcquaNet) e a Rede A. ....58

Tabela 6.6 - Prioridades das demandas e volumes para as regras de operação.....59

Tabela 6.7 - Soma quadrática das diferenças $(\mathrm{Sq})$, correlação $(r)$, raiz do erro quadrático médio (RMSE) e coeficiente de eficiência de Nash-Sutcliffe, entre os resultados da PD (etapa 1) e a Rede B.

Tabela 6.8 - Regras de operação por faixas.

Tabela 6.9 - Regra de operação vigente do SC e Regra 4. 
Tabela 6.10 - Maior número de meses consecutivos em determinada nas faixas de operação.

Tabela 6.11 - Resultados comparativos das regras com relação aos valores médios de vazões fornecidas às demandas $\left(\mathrm{m}^{3} / \mathrm{s}\right)$.

Tabela 6.12 - Resultados comparativos das regras operativas em termos dos déficits de atendimento às demandas. 


\section{SUMÁRIO}

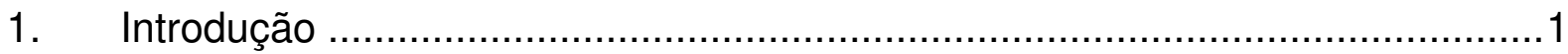

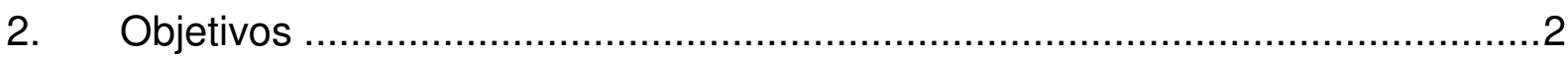

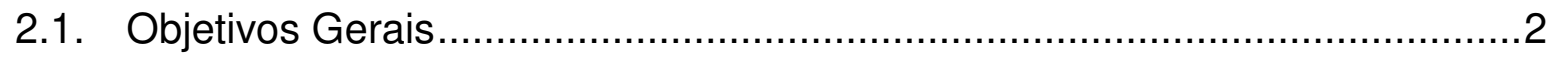

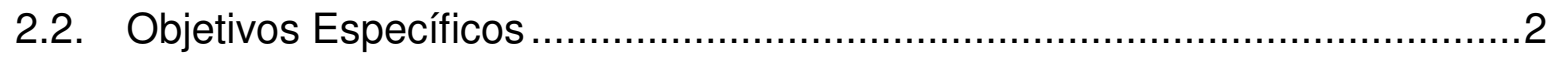

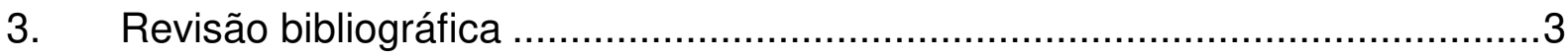

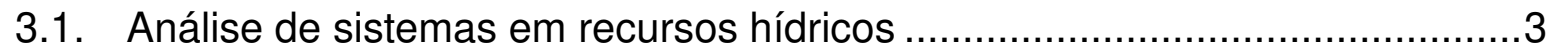

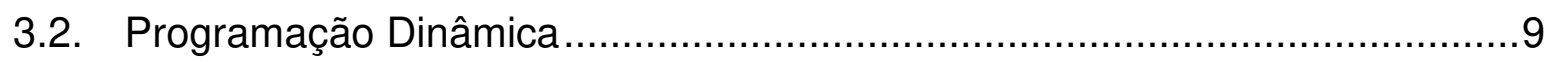

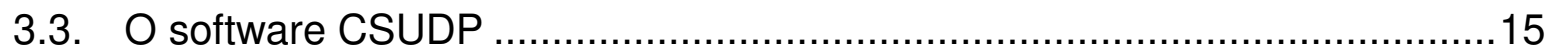

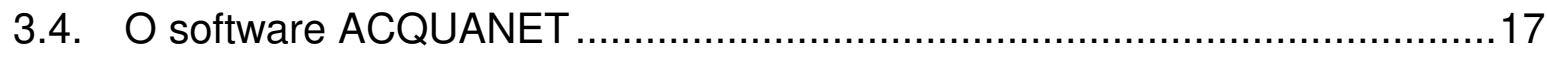

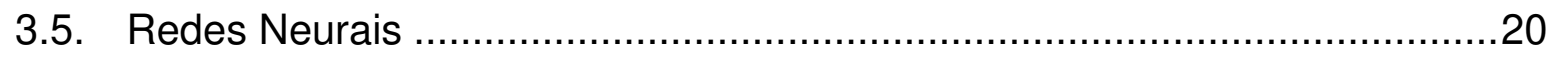

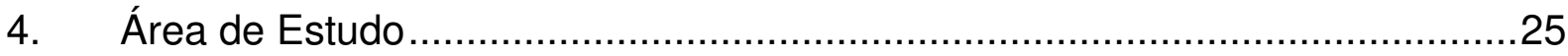

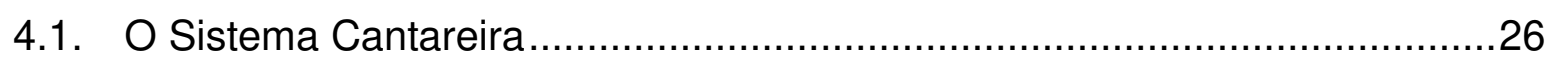

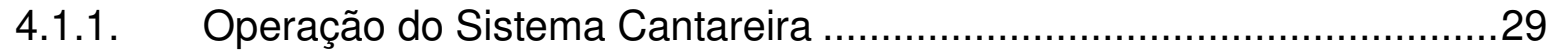

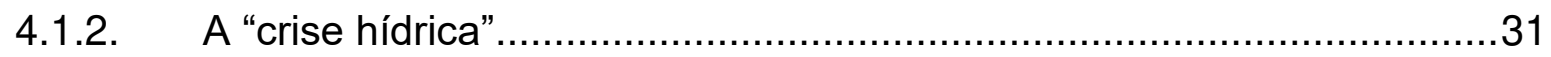

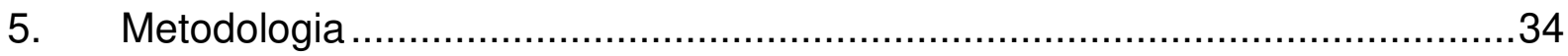

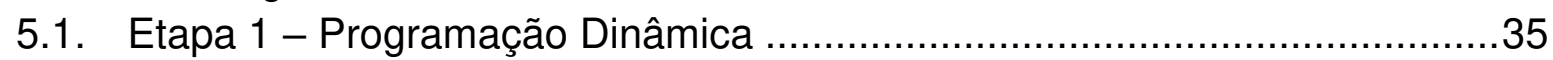

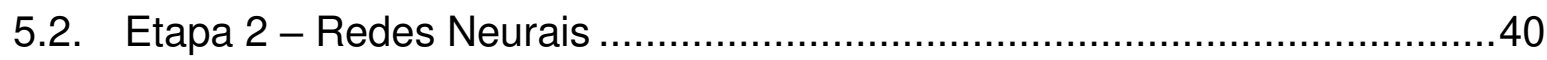

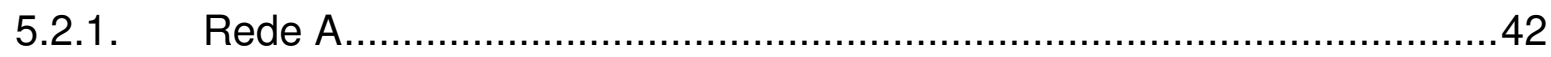

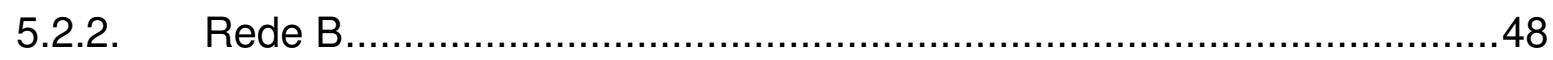

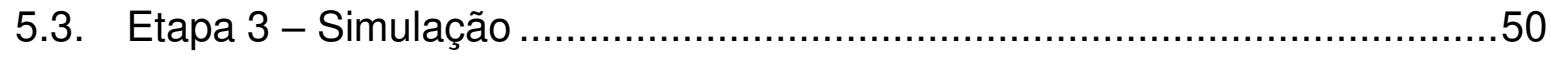

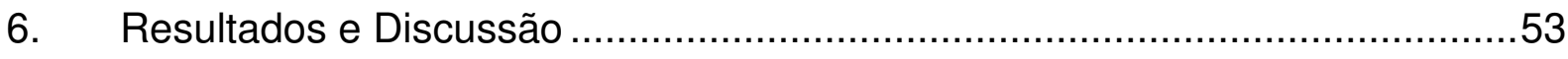

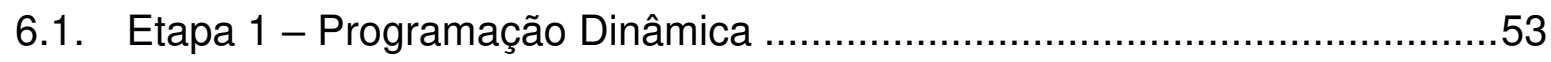

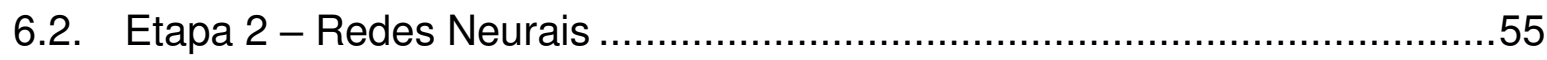

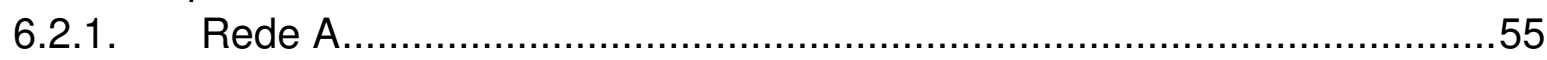

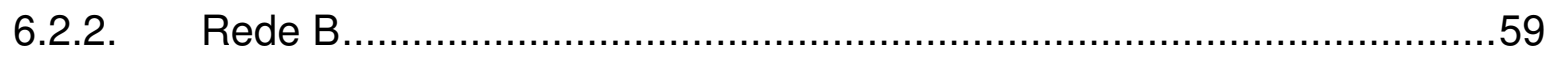

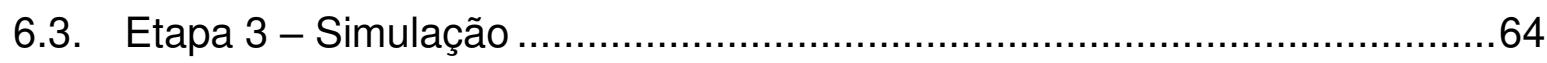

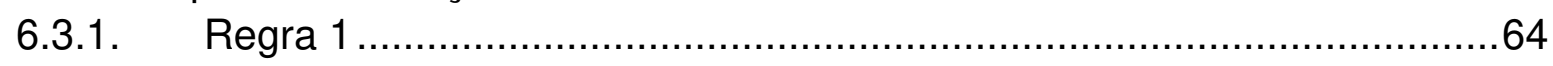

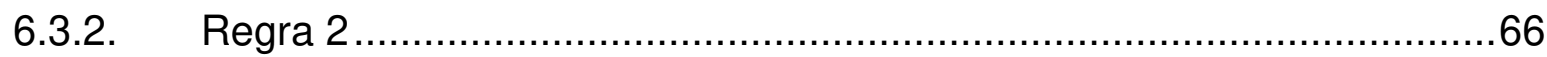

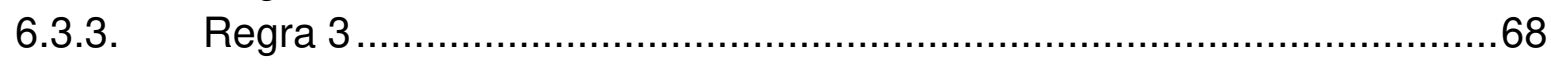

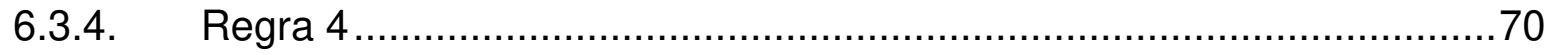

6.3.5. Desempenho das regras operativas ……........................................

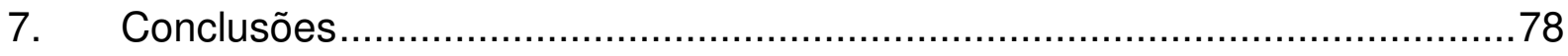

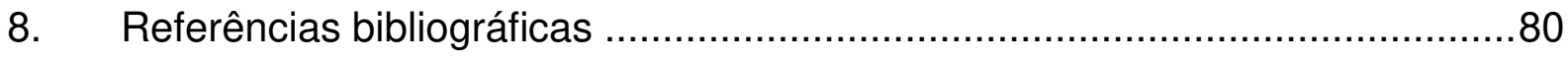





\section{INTRODUÇÃO}

Sistemas de recursos hídricos estão associados a grandes investimentos e políticas complexas de operação, cuja gestão sofre a influência de diversos fatores ambientais e socioeconômicos. Daí a necessidade de planejamentos estratégicos que conciliem eficiência econômica, sustentabilidade, flexibilidade e equidade (PORTO et al, 1997). Reservatórios são elementos importantes destes sistemas devido aos seus usos múltiplos e não raro conflitantes, como controle de cheias, armazenamento e distribuição de água, navegação, irrigação, geração de energia e outros (SIMONOVIC, 1992).

O avanço de ferramentas computacionais nas últimas décadas possibilitou o desenvolvimento de técnicas de simulação e de otimização que auxiliam a abordagem sistêmica de recursos hídricos. Neste contexto os Sistemas de Suporte à Decisão (SSD) vem se popularizando como ferramentas de apoio ao processo de tomada de decisão, utilizando-se comumente de técnicas combinadas de otimização e simulação, auxiliando também na abordagem das incertezas e em análises de risco.

Este trabalho propõe-se a desenvolver e avaliar regras de operação para os Sistema Cantareira, utilizando-se modelos combinados de otimização por programação dinâmica (PD) e de rede neural artificial (RNA), e de simulação com auxílio do software Acquanet, desenvolvido e consolidado pelo Laboratório de Sistemas de Suporte à Decisão (LabSid) da USP. 


\section{OBJETIVOS}

\subsection{OBJETIVOS GERAIS}

No contexto de modelos para avaliação e análise de sistemas complexos em recursos hídricos, este trabalho propõe-se a aplicar uma metodologia para obtenção de regras operativas de reservatórios, baseada em modelos de otimização, com o objetivo de avaliar seu desempenho em uma série histórica mediante os resultados de atendimento às demandas.

\subsection{OBJETIVOS ESPECÍFICOS}

Como objetivos específicos, podem-se citar:

- Revisão do estado da arte de bases metodológicas de modelos de Programação Dinâmica (PD) e Redes Neurais Artificiais (RNA) aplicados a sistemas de recursos hídricos;

- Desenvolvimento de uma metodologia para obtenção de regras operativas de reservatórios por meio do uso combinado de técnicas de otimização e simulação;

- Aplicação de modelos de PD e de RNA no Sistema Cantareira;

- Simulação de regras de operação obtidas com auxílio do software AcquaNet para uma série histórica;

- Análise do comportamento das regras quanto aos riscos de abastecimento das demandas. 


\section{REVISÃo BIBLIOGRÁFICA}

A revisão bibliográfica tem como objetivo subsidiar e consolidar o embasamento teórico do trabalho, de acordo com aplicações relevantes na literatura acadêmica em recursos hídricos.

As seções seguintes descrevem conceitos e definições sobre análise sistêmica em recursos hídricos, sobre modelos de otimização por Programação Dinâmica (PD), e por Redes Neurais Artificiais (RNA). Além disso apresenta-se dois softwares utilizados em sistemas de otimização e simulação de recursos hídricos, o CSUDP e o AcquaNet.

\subsection{ANÁLISE DE SISTEMAS EM RECURSOS HÍDRICOS}

Os sistemas de recursos hídricos estão intimamente ligados ao desenvolvimento socioeconômico da humanidade (LOUCKS, 2005). De acordo com Simonovic (1992), os reservatórios são os principais e mais complexos elementos destes sistemas, por serem utilizados para distribuição e controle da água tanto temporal quanto espacialmente.

Os reservatórios podem servir a um único ou a múltiplos propósitos como geração de energia, armazenamento de água para irrigação, abastecimento de água para consumo doméstico e industrial, recreação, controle de qualidade de corpos hídricos, controle de cheias, navegação, propósitos de conservação ambiental e entre outros (NANDALAL e BOGARDI, 2007). Para Loucks (2005) devido aos múltiplos propósitos dos sistemas de reservatórios, não raro, surgem situações potencialmente conflitantes. Estas características conferem grande complexidade ao processo decisório em sistemas de reservatórios (LANNA, 1997).

Em geral os sistemas de recursos hídricos estão associados a investimentos de grande porte, prazos longos e políticas cuidadosas de operação e manutenção, daí a necessidade de planejamentos que conciliem eficiência econômica, sustentabilidade, flexibilidade e equidade (PORTO e AZEVEDO, 1997). Labadie 
(2004) ressalta que, devido às crescentes pressões legais, ambientais e econômicas relacionadas à construção de novos empreendimentos de grande escala desta natureza, é importante a melhoria dos modelos e técnicas de operação, a fim de maximizar os benefícios dos sistemas já existentes.

Com efeito, gestão e planejamento eficientes dos mesmos são essenciais tanto para minimizar os conflitos decorrentes de objetivos divergentes, quanto para maximizar os benefícios provenientes da utilização da água como recurso tendo em vista as mudanças nos padrões da sociedade (LOUCKS, 2005).

Segundo Simonovic (2009) são notáveis os avanços na área de gestão de recursos hídricos e consequentemente, de sistemas de reservatórios observados nas últimas quatro décadas. Para o autor, os aspectos que mais contribuíram para isto foram o desenvolvimento da abordagem sistêmica e do campo da pesquisa operacional, que permitiram o surgimento de modelos de simulação e de técnicas matemáticas de otimização de sistemas.

Lanna (1997) define a abordagem sistêmica como sendo um processo relacionado à abstração ou simplificação de um problema complexo de forma que sejam mantidas as informações mais relevantes para a solução. Esta abordagem possui dois propósitos, o de otimizar os processos decisórios que atuam sobre a realidade do sistema ou o de simular o comportamento do mesmo, sob certas condições.

Loucks (2005) aponta que a simulação contínua de múltiplos cenários a fim de determinar a melhor política de gestão pode ser uma prática exaustiva ou até inviável, daí a popularização de técnicas conjuntas de otimização e simulação. Os modelos de otimização são ideais para determinar quais as melhores estratégias a serem incorporadas em modelos de simulação.

Nas áreas de gestão em sistemas naturais a incerteza é inerente à maioria dos processos, e deve ser incorporada aos modelos de otimização ou de simulação a depender dos objetivos da análise (KARAMOUZ et al, 2003). Em sistemas de recursos hídricos existem as incertezas que determinam a disponibilidade ou não de água, e as incertezas que influem sobre as características das demandas ao longo do tempo (PORTO et al, 1997). Nandalal e Bogardi (2007) afirmam que para análises em longo 
prazo de sistemas de reservatórios é fundamental incorporar estas incertezas na modelagem.

Quanto ao tratamento das incertezas, os modelos de simulação e de otimização são classificados em determinísticos ou estocásticos, podendo ser implicitamente ou explicitamente estocásticos (PORTO et al, 1997). Modelos determinísticos não consideram a aleatoriedade das variáveis, enquanto os modelos estocásticos apresentam elementos que definem um comportamento probabilístico entre os dados de entrada e os dados de saída (KARAMOUZ et al, 2003).

Em análises de sistemas de reservatórios com abordagens explicitamente estocásticas, a distribuição probabilística da série hidrológica é incorporada ao modelo matemático que descreve o sistema. Já nas abordagens implicitamente estocásticas, a série disponível é utilizada para gerar sinteticamente séries hidrológicas a serem incorporadas ao modelo determinístico (NANDALAL e BOGARDI, 2007). A Figura 3.1 apresenta as abordagens implicitamente e explicitamente estocásticas em técnicas conjuntas de otimização seguida por simulação, aplicadas à operação de reservatórios conforme demonstradas por Labadie (2004).

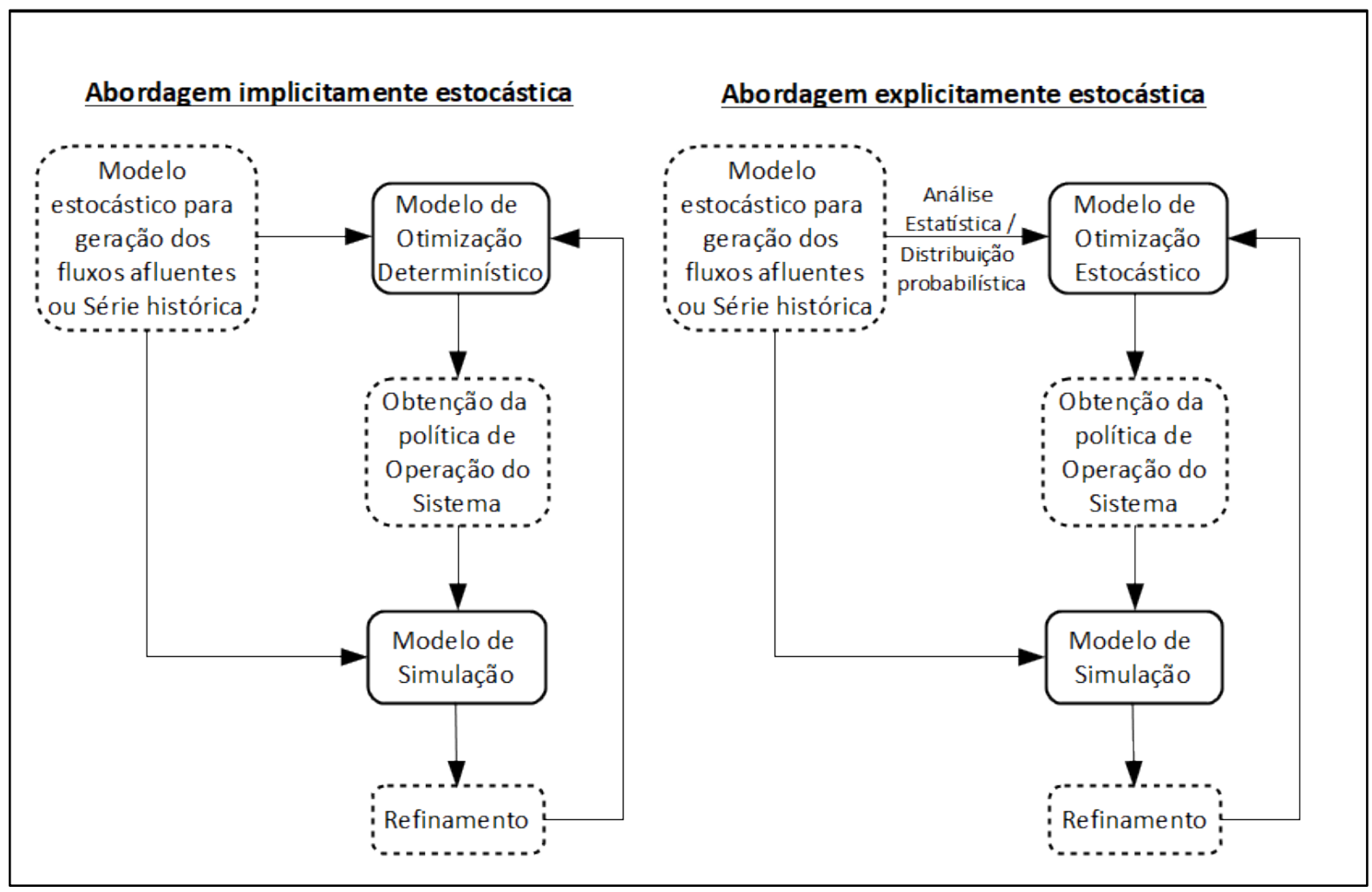

Figura 3.1 - Representação esquemática da abordagem de modelos implicitamente e explicitamente estocásticos aplicados à operação de reservatórios. Fonte: LABADIE, 2004. 
Técnicas de simulação e de otimização têm sido amplamente aplicadas em análises de sistemas de reservatórios na literatura. Yeh (1985) apresentou importante revisão do estado da arte, classificando os principais métodos de análise existentes genericamente em Programação Linear (PL), Programação Dinâmica (PD), Programação Não Linear (PNL) e modelos de simulação. Simonovic (1992) explorou exemplos práticos de aplicação conjunta de modelos de simulação e de técnicas de otimização para reservatórios. Wurbs (1993) apresentou uma comparação de modelos de simulação, de otimização e de técnicas conjuntas a fim de fornecer subsídios para escolha da técnica mais eficiente de acordo com o objetivo da análise de sistemas de reservatórios. Labadie (2004) também apresentou importante atualização do estado da arte em modelos de simulação e otimização aplicados à sistemas de reservatórios. Rani e Moreira (2010) discorrem sobre as principais aplicações de modelos de simulação, de otimização e aplicação conjunta apresentadas na literatura para análises de operação de reservatórios.

Modelos de otimização são compostos por funções objetivo, variáveis de decisão desconhecidas e por restrições, e envolvem algum tipo de programação matemática ou computacional (SIMONOVIC, 1992). O objetivo da otimização é encontrar o conjunto das variáveis de decisão, que maximize ou minimize o objetivo formulado para o problema. As restrições são expressas em funções de igualdade ou desigualdade, em termos das variáveis de decisão e dos parâmetros a partir dos quais o problema é formulado. O resultado do modelo sofre influência tanto dos parâmetros fornecidos, das restrições, da função objetivo e especialmente da modelagem do problema (LOUCKS, 2005).

A PL é uma das técnicas de otimização mais populares para aplicação em sistemas de reservatórios (RANI e MOREIRA, 2010). Sua principal característica é que tanto a função objetivo quanto as restrições que regem o modelo são lineares. As principais vantagens da PL são a capacidade de manipular problemas de grandes dimensões e facilidade de obtenção da solução ótima global (YEH, 1985).

Em alguns casos não é possível linearizar o problema de otimização, sendo necessária a utilização de técnicas conhecidas como programação não linear (PNL). Algoritmos de PNL são robustos e possuem a vantagem de facilitar a resolução de problemas mais complexos (LABADIE, 2004) porém a principal dificuldade é que os mesmos não são capazes de garantir o resultado ótimo global, a depender da 
formulação do problema. Atualmente há diversos pacotes computacionais eficientes para a resolução de problemas de PL e PNL como o MINOS e o GAMS (SIMONOVIC, 2009).

A maioria dos problemas formulados para análise em recursos hídricos podem ser resolvidos de forma sequencial no tempo e no espaço. Devido a esta característica a técnica de PD é ideal para resolver problemas que apresentam este comportamento. A modelagem da PD não é restrita à linearidade na formulação, permitindo que complexidades do sistema sejam incorporadas na modelagem (YEH, 1985).

Com a crescente capacidade computacional e o interesse por técnicas de otimização que possibilitem superar as limitações dos métodos convencionais, um grupo de modelos impulsionados pela inteligência artificial (IA) tem se destacado. Exemplo destes modelos são os Algoritmos evolucionários ( $A E$ ), a lógica difusa (fuzzy logic), e a redes neurais artificiais (RNA) (RANI e MOREIRA, 2010).

Os algoritmos evolucionários são inspirados em processos biológicos e tem ganhado espaço em aplicações para análises com múltiplos objetivos, sujeitas a não linearidade e a descontinuidades (SIMONOVIC, 2009).

A lógica difusa (fuzzy logic) é uma técnica de otimização ideal para lidar com conceitos subjetivos ou qualitativos no processo decisório (RANI e MOREIRA, 2010), aproximando-se do pensamento humano e que ao contrário da lógica booleana, admite valores intermediários entre o "falso" e o "verdadeiro" (ZUFFO, 2010). Em particular no caso de sistemas de reservatórios, a aplicação desta técnica é grande interesse para inferência de regras operativas (RANI e MOREIRA, 2010).

As Redes Neurais Artificiais (RNA) têm sido amplamente aplicadas a análises em sistemas de recursos hídricos (CHANDRAMOULI e DEKA, 2005). Uma das características vantajosas da rede neural é o reconhecimento de comportamentos desconhecidos ou complexos da relação entre dados de entrada e saída a partir do treinamento da rede (RANI e MOREIRA, 2010).

Devido à sua complexidade em diversos casos, são necessárias aproximações e simplificações do sistema real para que o modelo de otimização tenha um resultado factível, o que torna recomendável o uso de modelos de simulação para posterior validação do comportamento do sistema (LOUCKS, 2005). Simulação é descrita como uma abordagem sistêmica utilizada para analisar o comportamento temporal ou 
espacial aproximado de um sistema em um computador (LANNA, 2005). Modelos de simulação têm sido amplamente aplicados em sistemas de recursos hídricos, apresentando-se como ferramentas úteis de gestão e planejamento (SIMONOVIC, 2009). Labadie (2004) aponta que diferentemente dos modelos de otimização, os modelos de simulação permitem verificar o desempenho dos sistemas perante diferentes estratégias de gestão ou cenários distintos.

Nas últimas décadas os avanços computacionais possibilitaram 0 desenvolvimento e popularização de diversos pacotes de simulação voltados à gestão e planejamento de recursos hídricos. Dentre os pacotes relevantes estão os diversos modelos HEC (HEC-3, HEC-5, HEC-ResSim) e RAS desenvolvidos pelo Hydrologic Engineering Center, para análise de controle de cheias, abastecimento de água e sistemas em rede de fluxo, e de sistemas fluviais respectivamente (SIMONOVIC, 2009).

A complexidade dos problemas em recursos hídricos tem mostrado a necessidade de integrar abordagens sistêmicas e modelos a fim de facilitar a interpretação e qualidade dos resultados. Tal conjunto de ferramentas integradas pode ser chamado de Sistema de Suporte à Decisão (SSD) (BRAGA et al 1998). Os SSDs são ferramentas computacionais compostas genericamente por um banco ou base de dados, banco de modelos e interface amigável, cujo objetivo é auxiliar e apoiar o processo decisório (PORTO et. al, 1997). Atualmente, uma variedade de SSDs estão disponíveis para análise de sistemas em recursos hídricos como o MODSIM, o AQUATOOL e o AcquaNet.

O MODSIM é um SSD voltado à gestão de recursos hídricos, capaz de otimizar e simular sistemas de redes de fluxo. O modelo é utilizado em análises a curto e longo prazo de sistemas fluviais complexos, operação de reservatórios para abastecimento de água e geração de energia, alocação de água, entre outros (LABADIE, 2010). AQUATOOL é um SSD generalizado para planejamento de bacias complexas representadas em redes de fluxo, que inclui módulos de gestão operacional (ANDREU et al, 1996).

O programa AcquaNet, desenvolvido a pelo Laboratório de Sistemas de Suporte a Decisões da Escola Politécnica da USP, é de ampla aplicação em sistemas de recursos hídricos representados em rede de fluxo (SCHARDONG, 2006). 


\subsection{PROGRAMAÇÃO DINÂMICA}

A Programação Dinâmica (PD) é uma técnica de pesquisa operacional ideal para processos decisórios sequenciais ou de múltiplos estágios (YEH, 1985). Ao contrário da PL, a PD não é restrita a uma estrutura linear de formulação, permitindo analisar problemas não lineares na função objetivo e nas restrições (SIMONOVIC, 1992). Por conta disso, tem sido amplamente aplicada em problemas de engenharia de recursos hídricos como operação de reservatórios, alocação de água em sistemas hídricos e em expansão de capacidade de infraestruturas (LOUCKS, 2005).

Um problema de otimização por PD envolve estágios, estados e decisões. Cada estágio possui um número de estados e decisões possíveis, e as decisões implicam na mudança de estado do sistema (LOUCKS, 2005). Em aplicações para operação de reservatórios, é usual definir o armazenamento do sistema como a variável de estado, a vazão de descarga como a variável de decisão e os períodos de tempo como estágios (SIMONOVIC, 1992).

A PD é baseada no "princípio da otimalidade" que dispõe que as decisões ótimas remanescentes para um sistema qualquer, dado seu estado atual, são independentes dos seus estados anteriores (BELLMAN, 1957). Este princípio mostra a principal característica da PD que é a possibilidade de divisão do problema principal em subproblemas para cada conjunto de estados possíveis em cada estágio do processo. O princípio da otimalidade é incorporado ao modelo de otimização através da chamada função recursiva, que acumula as soluções ótimas a cada estágio sucessivamente, até gerar uma política decisória que atenda a função objetivo. As funções recursivas podem resolver o problema de forma progressiva ou regressiva (LABADIE, 2004; LOUCKS, 2005).

Quando não há razão especial para se escolher a resolução progressiva ou regressiva, normalmente a resolução regressiva é mais utilizada, sendo esta forma fundamental em problemas estocásticos (YEH, 1985).

Labadie (2004) mostra que um problema de operação de reservatórios pode ser representado em um processo de decisões sequenciais multi-estágio, conforme 
mostra a Figura 3.2, em que a cada estágio as decisões tomadas em termos das vazões de descarga, geram um benefício ou custo descrito genericamente por uma função $f$, e o levam ao estado seguinte.

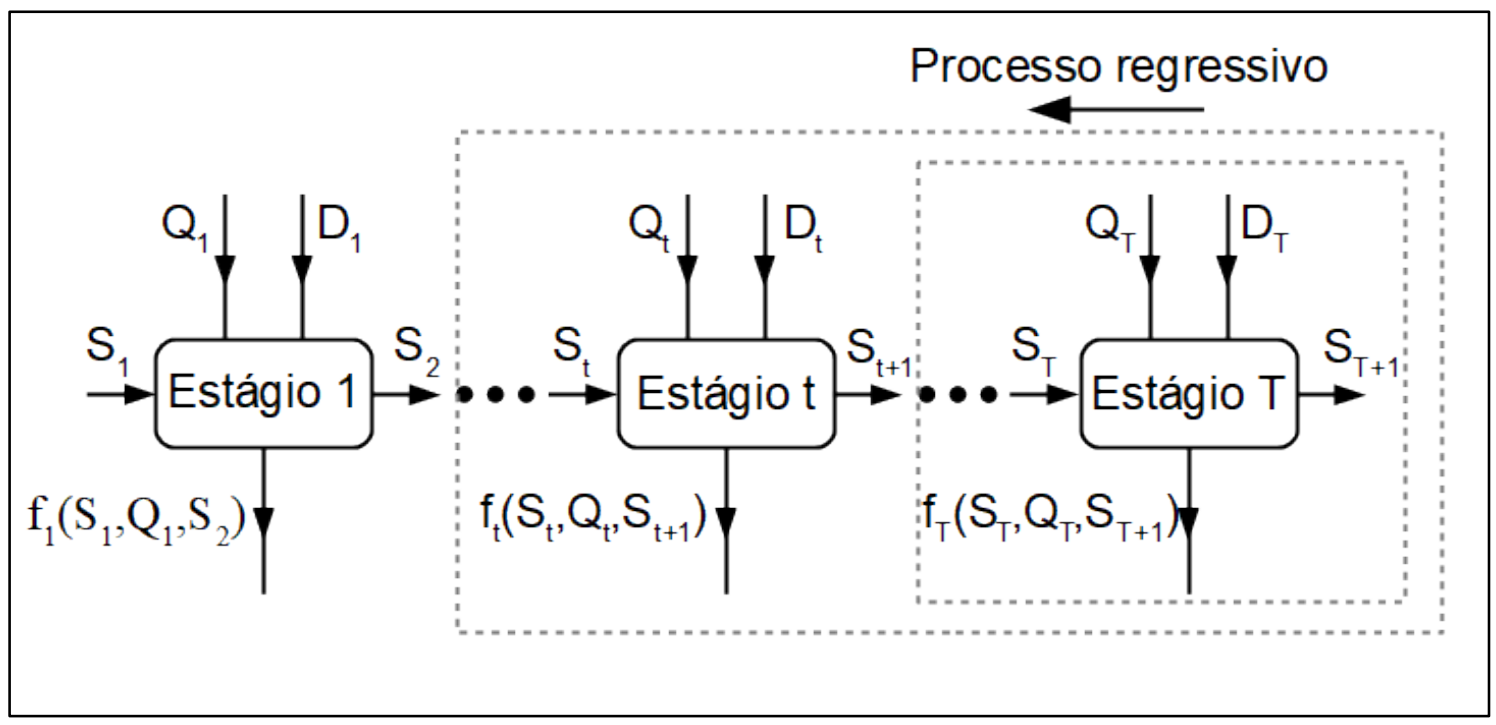

Figura 3.2- Esquema de operação de reservatório representada como um processo de decisão sequencial ou em estágios. Fonte: LABADIE, 2004.

Onde:

- $\mathrm{S}$ - volume armazenado;

- Q - vazão afluente;

- D - descarga;

- $f$ - função de retorno, ou resultado das decisões.

Genericamente uma função recursiva de PD pode ser escrita conforme mostram Nandalal e Bogardi (2007) pela equação 3.1:

$$
f_{t}^{*}\left(S_{t}\right)=\max _{x_{t}}\left\{C_{S_{t}}\left(\mathrm{~S}_{\mathrm{t}}, \mathrm{x}_{\mathrm{t}}\right)+f_{t+1}^{*}\left(S_{t+1}\right)\right\}
$$

- t - estágio;

- $S_{t}$ - estado do sistema no estágio t;

- $x_{t}-$ decisão tomada no estágio t;

- $S_{t+1}$ - função de transformação de estado, para o estado posterior; 
- $C_{S t}$ - custo ou benefício proveniente da decisão $x_{t}$ para o estado $S_{t}$, descrito pelo objetivo do modelo;

- $f^{\star}{ }_{t+1}$ - custos ou benefícios ótimos acumulados para os próximos estágios $t+1$, $\mathrm{t}+2 \ldots \mathrm{T}$

- T - número total de estágios.

Em modelos para operação de reservatórios, a função de transformação de estado é dada pelo balanço de massa do sistema, expresso pela equação 3.2 (YEH, 1985):

$$
S_{t+1}=S_{t}+Q_{t}-D_{t}-P_{t}
$$

Em que $\mathrm{P}_{\mathrm{t}}$ expressa as perdas do sistema, como a perda decorrente da evaporação por exemplo. O modelo é sujeito às restrições:

$$
\begin{aligned}
& S_{\text {mín }} \leq S_{t} \leq S_{\text {máx }} \\
& D_{\text {mín }} \leq D_{t} \leq D_{\text {máx }} \\
& D_{t} \leq S_{t}+Q_{t}-P_{t}
\end{aligned}
$$

\section{Em que:}

- Smín e Smáx - indicam os armazenamentos mínimo e máximo do sistema;

- Dmín e Dmáx - indicam as condições de descarga mínima e máxima;

Uma das características importantes da PD é que na busca pelas decisões ótimas a cada estágio, são geradas informações complementares úteis para análise do sistema sob outros aspectos (PORTO et al, 1997). Para aplicação prática em problemas de otimização de reservatórios, a PD é usualmente aplicada na sua forma discreta em que a variável de estado (volume do reservatório) é discretizada (LABADIE, 2004).

Em sistemas de múltiplos reservatórios, ou com múltiplas variáveis de estado, o número de combinações a serem calculadas aumentam exponencialmente, este 
fenômeno é conhecido como o "mal da dimensionalidade" (NANDALAL \& BOGARDI, 2007). Os problemas multidimensionais tornam a determinação da solução ótima global mais complexa (PORTO et al, 1997). Porém, algumas técnicas auxiliares são comumente utilizadas para lidar com a multidimensionalidade como a PD incremental (IDP) e PD por aproximações sucessivas (DPSA) (YEH, 1985).

Conceitualmente descrita por Larson (1968, apud YEH, 1985) a PD incremental é um processo iterativo que se inicia com um resultado possível admitido para o vetor de decisões, chamado "trajetória inicial", definida pelo programador que gera um valor inicial para a função objetivo (YEH, 1985). Em seguida o algoritmo percorre um corredor em torno da trajetória inicial, dado por incrementos específicos fornecidos pelo programador, e examina para cada valor o resultado da função objetivo. Caso algum dos valores vizinhos produza melhores resultados para a função objetivo do que o valor da trajetória inicial, este substitui automaticamente a posição correspondente na nova trajetória. A cada iteração a trajetória ótima é atualizada, e um corredor é novamente percorrido pelo algoritmo até a convergência ou o critério de parada. O processo é sensível aos valores incrementais e ao valor da trajetória inicial (NANDALAL e BOGARDI, 2007). A Figura 3.3 apresenta o corredor de estados possíveis formado pelos incrementos a partir da trajetória inicial, em que St representa o estado do sistema no estágio t.

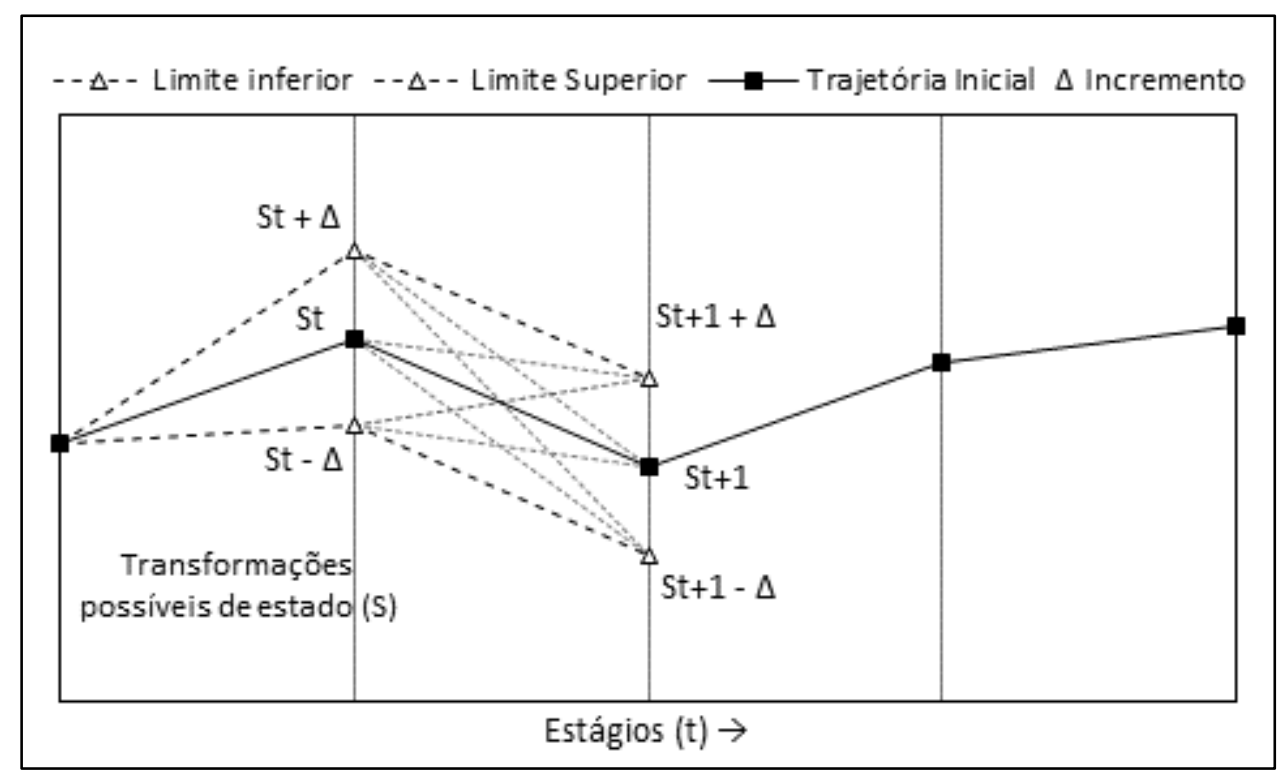

Figura 3.3 - Construção do corredor para iterações do algoritmo IDP, Fonte: NANDALAL e BOGARDI, 2007. 
Turgeon (1982) demonstrou que a IDP pode não convergir para um resultado ótimo se for utilizado o mesmo incremento em todas as iterações do problema. Para eliminar esta possiblidade, é usual fornecer incrementos que diminuam progressivamente a largura do corredor de estados possíveis à medida que os testes com o modelo de otimização avancem. Também se pode variar a trajetória inicial a fim de garantir que o resultado encontrado é o valor ótimo global para a função objetivo (NANDALAL e BOGARDI, 2007).

O processo da DPSA baseia-se no conceito de que o problema multidimensional de origem pode ser decomposto em subproblemas unidimensionais de modo que sejam otimizados separadamente. Ao invés de avaliar todas as combinações possíveis das variáveis de estado, o algoritmo da DPSA otimiza um componente por vez, e analogamente à IDP exige o fornecimento de uma trajetória inicial (LABADIE, 2004).

A combinação da DPSA seguida por IDP possibilita a convergência rápida para a solução ótima local seguida do refinamento e/ou confirmação do resultado, apresentando-se como uma estratégia prática e satisfatória para o tratamento de problemas multidimensionais (LABADIE, 2014).

A formulação de problemas em PD pode ser tanto determinística quanto implicitamente ou explicitamente estocástica. Yeh (1985) afirma que a PD determinística (PDD) é válida para análise de problemas a curto prazo, como poucos meses ou anos, mas para análise a longo prazo convém considerar as incertezas das séries hidrológicas nos modelos.

A programação dinâmica estocástica (PDE) incorpora a aleatoriedade dos fenômenos à PD clássica (PORTO et al, 1997). Na forma implícita são geradas uma ou mais séries históricas sintéticas, um processo conhecido como simulação de Monte Carlo, para posterior aplicação da PD determinística. Na forma explícita, é considerada no modelo a distribuição de probabilidades que representam o comportamento aleatório das vazões afluentes ao sistema. Uma das formas que isso é feito é através de processos markovianos (NANDALAL e BOGARDI, 2007).

Em análises de sistemas de recursos hídricos, é comum que os influxos sejam considerados processos markovianos (YEH, 1985). Um processo markoviano de primeira ordem possui a propriedade de que a distribuição de probabilidades do 
próximo estado depende apenas do estado atual e não da sequência de estados que o precederam. A discretização das variáveis de estados possíveis dá origem às cadeias de Markov (LOUCKS, 2005). A partir do histórico de vazões afluentes a um sistema de reservatórios, é possível obter uma matriz de transição de probabilidades que represente o comportamento das vazões de influxo discretizadas mensalmente, artifício que facilita a aplicação de modelos estocásticos (NANDALAL e BOGARDI, 2007).

A resolução de problemas de PDE para sistemas com múltiplos reservatórios torna-se pouco prática devido ao mal da dimensionalidade, exigindo maior esforço computacional do que para casos implicitamente estocásticos ou determinísticos (RANI e MOREIRA, 2010).

Yakowitz (1982) afirma que virtualmente todos os problemas em recursos hídricos possuem variáveis com características de aleatoriedade, portanto as abordagens estocásticas são fundamentais. No entanto, para o autor, a abordagem determinística se justifica por dois fatores; o primeiro é que em certos casos, as vazões dos rios afluentes aos sistemas em análise são regulares o suficiente para se admitir que os dados conhecidos são semelhantes aos esperados para o mesmo período em estudo. E o segundo é a informação gerada pela abordagem determinística, de como poderia ser operado o sistema se as vazões fossem conhecidas.

Autores como Yeh (1985) e Labadie (2004) apresentaram importantes aplicações da PD em suas formas determinística e estocástica a sistemas para operação de reservatórios. Yakowitz (1982) apresentou um estudo de caso de aplicações da PD em análises de sistemas de recursos hídricos como controle ótimo para irrigação, alocação de água em sistemas de reservatórios, controle de sistemas tendo em vista fatores de qualidade da água, e operação de reservatórios.

Stedinger, Sule e Loucks (1984) demonstraram que os modelos de PDE apresentam melhor desempenho quanto melhores forem os modelos que descrevem o comportamento das variáveis hidrológicas. Karamouz e Houck (1987) apresentaram um estudo comparativo entre modelos de PDD e PDE aplicado a sistemas de reservatórios com o objetivo de obter regras operativas por análise regressiva. 0 estudo concluiu que as regras de operação obtidas por meio do modelo determinístico foram mais eficientes para operação de médios e grandes reservatórios, enquanto as 
regras obtidas por meio do modelo estocástico foram mais eficientes para operação de reservatórios de pequeno porte.

Braga et al (1991), aplicou a PDE para otimização de múltiplos reservatórios visando a produção de energia em reservatórios da bacia do rio Tietê. Karamouz e Vasiliadis (1992) aplicaram um modelo PDE a fim de obter políticas otimizadas de operação de reservatórios, a partir processos markovianos discretos para incorporar as transições das vazões afluentes ao sistema. Méllo Jr. e Matos (1999) formularam um modelo de PDE para otimização de um reservatório no estado de Sergipe, para fins de regularização de vazões. Nandalal e Bogardi (2007) também relatam diversas aplicações de PD a operações de reservatórios, evidenciando suas características e flexibilidade no tratamento de problemas desta natureza.

\subsection{O SOFTWARE CSUDP}

Parte da arte em PD está na modelagem do problema (YEH, 1985). A solução de problemas de otimização envolve muitos cálculos, o que pode desencorajar sua aplicação. Neste contexto, o software CSUDP desenvolvido por Labadie (2014) na década de 90 apresenta-se como uma ferramenta de livre acesso com grande potencial para resolução de problemas pela PD discreta. O programa permite a solução de problemas unidimensionais e multidimensionais, determinísticos e estocásticos (LABADIE, 2014). A Figura 3.4 mostra a tela de configurações gerais do software CSUDP.

Através de sua interface, é possível configurar as características principais de entrada do modelo de PD como o tipo de resolução progressivo ou regressivo; o número de estágios do problema, as discretizações e os limites de restrição das variáveis de estado e de decisão, conforme mostra a Figura 3.5. 


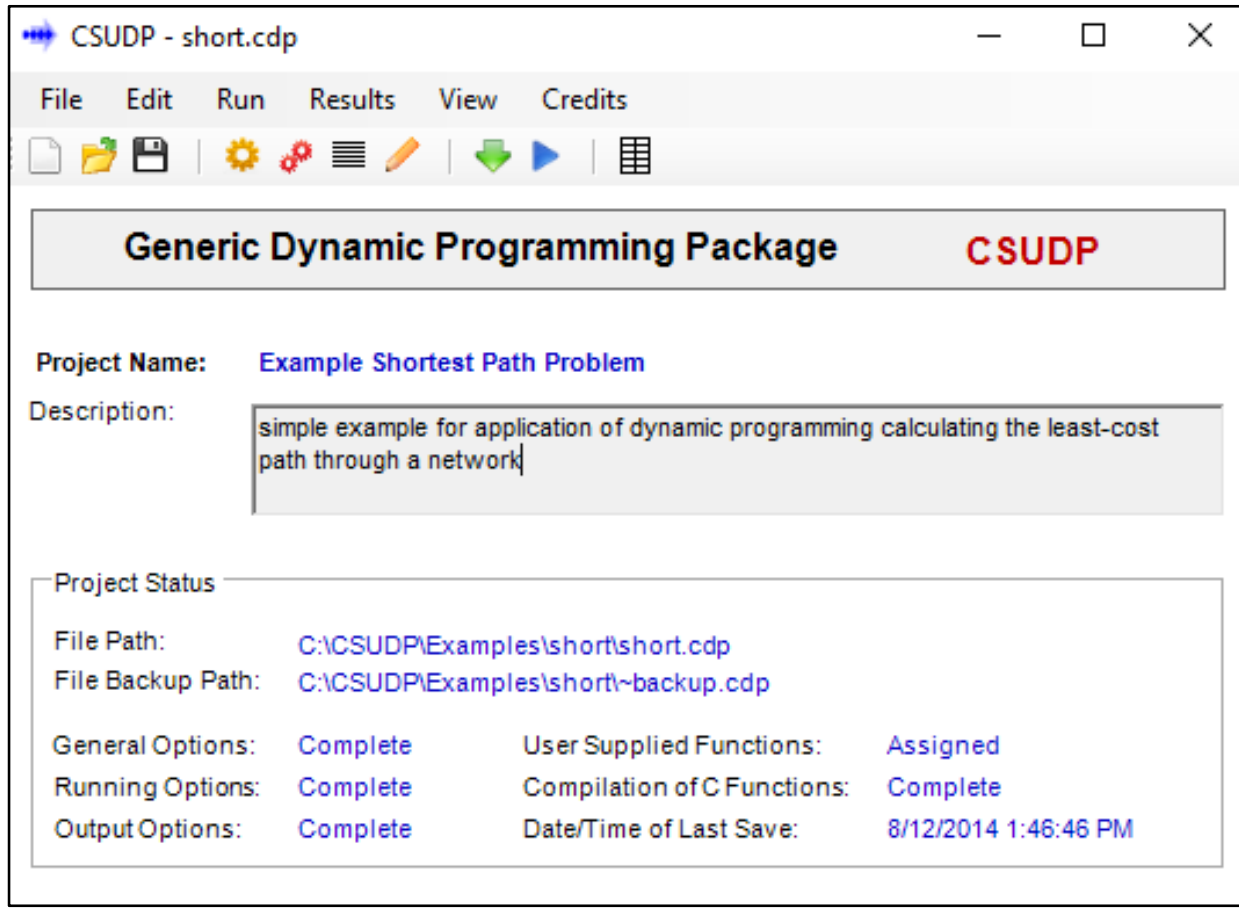

Figura 3.4 - Interface do programa CSUDP.

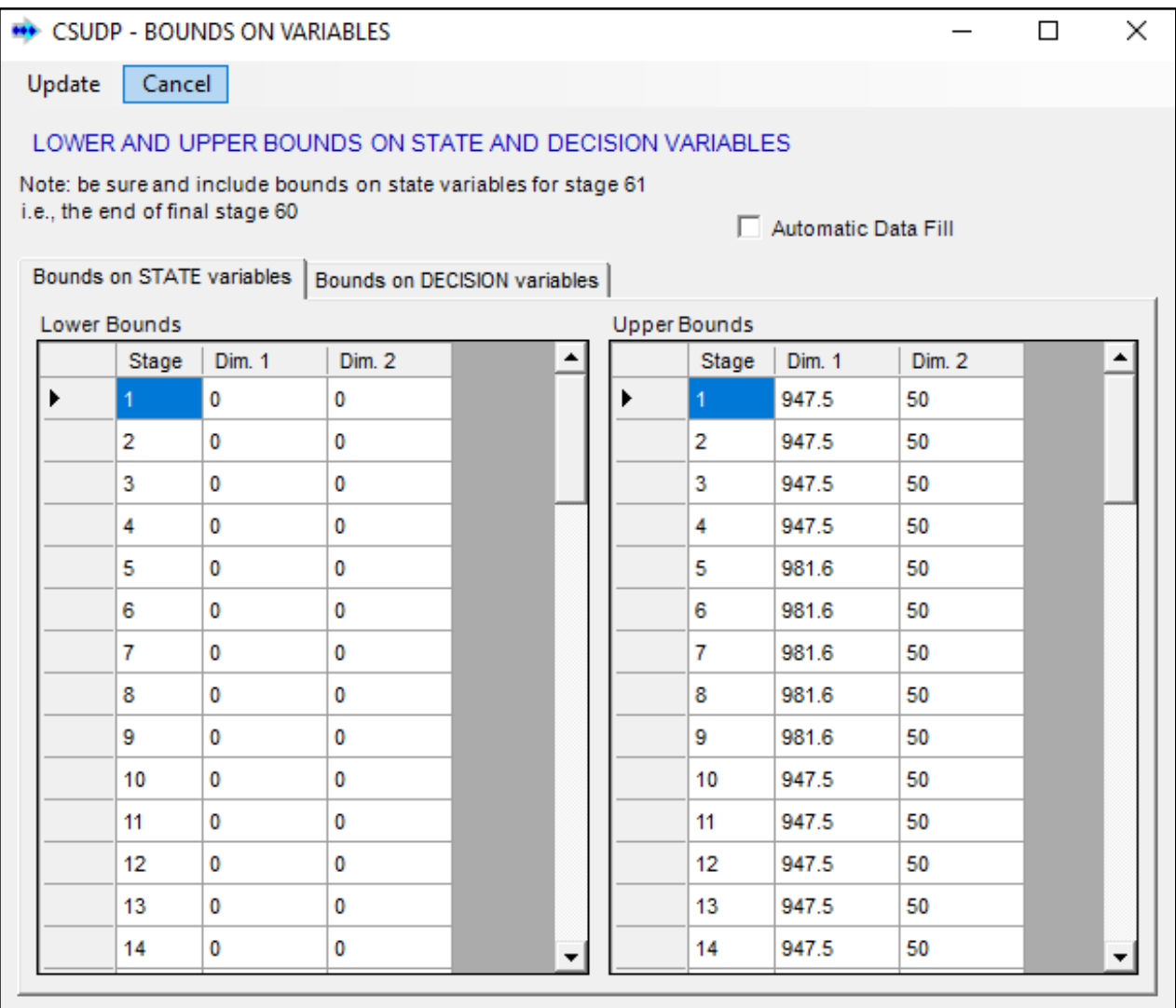

Figura 3.5 - CSUDP: Tela para configuração dos limites de restrição das variáveis. 
Para os cálculos do CSUDP é necessário que o usuário forneça as funções objetivo e de transformação de estado, além de uma função auxiliar, chamada "readin", que permite a leitura de dados suplementares em um arquivo externo, com a vantagem de fácil alteração do mesmo sem necessidade de alterar o modelo. Estas funções são programadas na linguagem $C$ e compiladas pelo próprio software que gera um arquivo executável específico para o sistema em estudo. A cada estágio é chamada a função de transformação de estado e a função de leitura de dados externos se houver necessidade, de modo que resultados são gravados e utilizados para cálculos subsequentes à chamada da função objetivo (LABADIE, 2014).

O programa permite que problemas unidimensionais de PD sejam resolvidos nas formas progressiva ou regressiva, e os problemas multidimensionais sejam resolvidos através da IDP, da DPSA e da combinação dos dois modelos, o que garante melhor convergência do resultado a um valor ótimo. Há a opção de obter o "caminho inicial" a partir do qual o modelo será otimizado, por meio dos valores médios fornecidos para os limites máximos e mínimo das variáveis de estado, o que fornece bons resultados para uma primeira aproximação do problema. O software resolve sistemas de até 30 variáveis de decisão por estágio nos casos determinísticos e com uma variável de decisão nos casos estocásticos (LABADIE, 2014).

\subsection{O SOFTWARE ACQUANET}

O AcquaNet é um SSD desenvolvido pelo Laboratório de Sistemas de Suporte a Decisões da Escola Politécnica da USP (LabSid) para simulação de bacias hidrográficas representadas em redes de fluxo (LABSID, 2015).

Inicialmente inspirado no programa ModSim, que se apresentava como uma eficiente ferramenta para resolver sistemas complexos de rede de fluxo para a solução do problema de alocação da água, o LabSid desenvolveu um software denominado ModSimP32. Esta ferramenta manteve o algoritmo de cálculo original, conhecido como out-of-Kilter, e contava com uma interface amigável para facilitar a entrada e manipulação de dados em ambiente Windows. Posteriormente foi criada uma versão denominada ModSimLS, que contava com a parte do armazenamento em banco de 
dados e com um executável próprio, baseado no original (PORTO et. al, 2003; PORTO et. al, 2005).

Diante da necessidade de incluir modelos e cálculos que tratassem de mais variedades de problemas em recursos hídricos, o novo SSD AcquaNet foi desenvolvido. O programa possui uma estrutura modular composta por um módulo base e por módulos para cálculos diversos de problemas de sistemas de recursos hídricos. O módulo base, de interface amigável, é responsável pela criação e edição do traçado do modelo, leitura, definição dos módulos ativos e da integração entre os diferentes módulos. O programa conta com uma base de dados que armazena os dados de entrada e as alterações feitas pelos usuários, bem como os resultados gerados (ROBERTO et. al, 2007).

Os principais módulos integrados pelo módulo de base do AcquaNet são o módulo de alocação de água, módulo de qualidade da água, módulo de irrigação, módulo de produção de energia, módulo de valor econômico da água e curvas de aversão ao risco (SCHARDONG, 2006). A Figura 3.6 mostra a interface do módulo base do SSD AcquaNet.

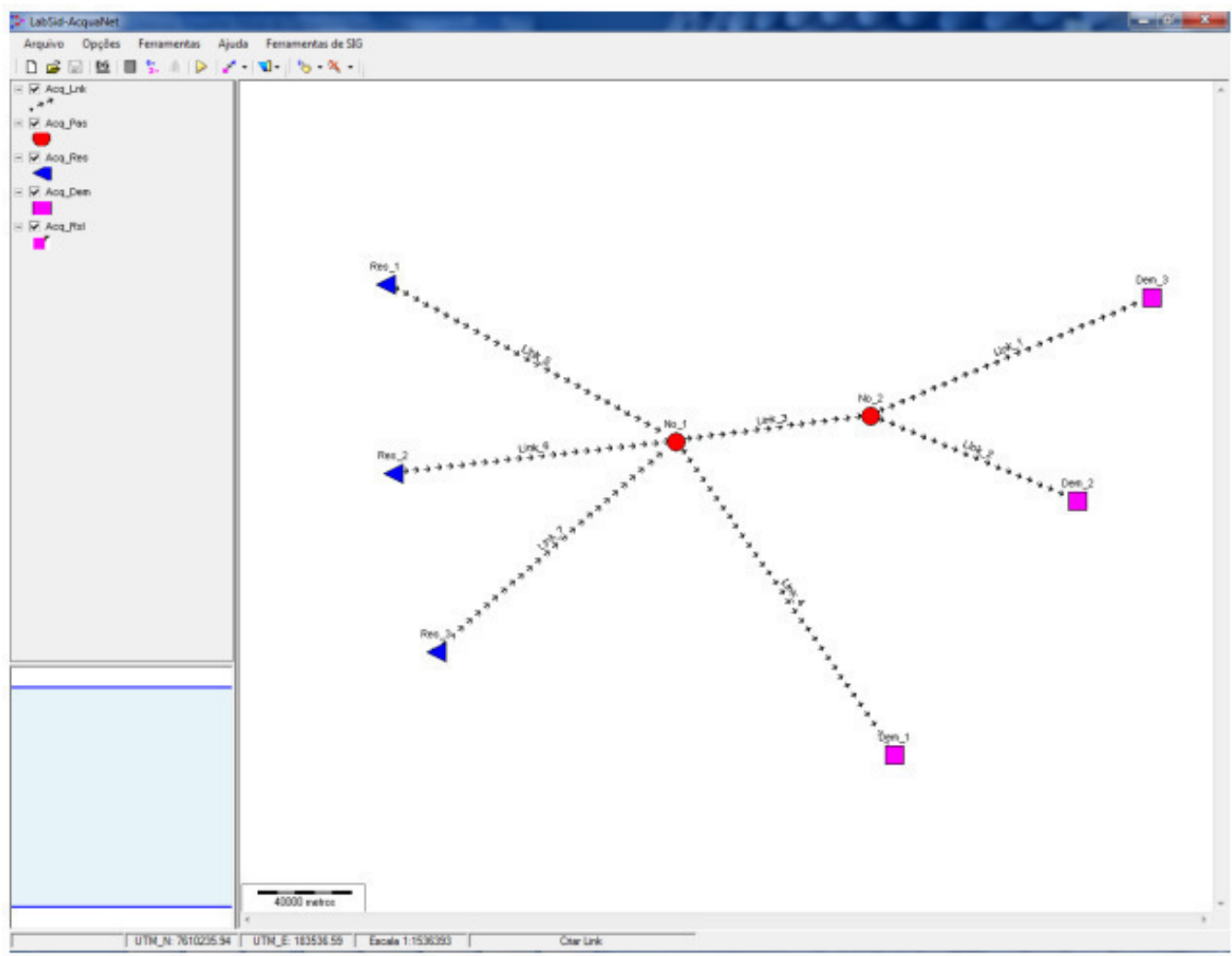

Figura 3.6 - Interface do SSD AcquaNet. 
No AcquaNet os componentes do sistema são representados em rede de fluxo. Os nós da rede podem representar os reservatórios (nós de volume) ou outras características do sistema como pontos de desvio, pontos de demanda ou pontos de entrada (nós de passagem). Os arcos da rede representam canais, adutoras e trechos de passagem naturais por exemplo, e são os elos entre os nós (PORTO et. al, 1997). O AcquaNet efetua uma otimização sequencial no tempo na forma da equação 3.6.

$$
\min \sum_{i=1}^{N} \sum_{i=1}^{N} c_{i j} \cdot q_{i j}
$$

Sujeito às restrições das equações 3.7 e 3.8 :

$$
\begin{aligned}
& \sum_{i \in I_{j}}^{N} q_{i j}-\sum_{k \in O_{j}}^{N} q_{j k}=0 \\
& I_{i j}<q_{i j}<U_{i j}
\end{aligned}
$$

Sendo:

qij - vazão média entre o nó i e o nó j durante o intervalo de tempo considerado;

Cij - custo unitário, que pode ser monetário ou um custo que represente direitos de água ou prioridades, calculado para cada nó segundo as prioridades definidas pelo usuário;

$\mathrm{l}_{\mathrm{j}}$ - conjunto de todos os nós com arcos que terminam no nó j;

$\mathrm{O}_{\mathrm{j}}$ - conjunto de todos os nós com arcos que se originam no nó j;

lij - vazão mínima no arco (i, j);

Uij: vazão máxima no arco (i, j).

O AcquaNet pode efetuar simulações de maneira sequencial no tempo, chamada "Simulação Contínua", ou estatisticamente no modo chamado "Planejamento Tático". Quanto às opções de cálculo, estão disponíveis os modos "Estados Hidrológicos" e "Calibração". Na primeira opção o modelo considera a quantidade de água armazenada nos reservatórios para determinar qual o valor de demanda, de volume meta e as prioridades que serão utilizadas no cálculo de cada um dos meses. Já na segunda, o modelo efetua os cálculos com os valores fornecidos sem considerar o estado atual do sistema (LABDSID, 2015). 
A opção de cálculo por estados hidrológicos é particularmente interessante para definir regras para operação do sistema baseadas nos estados de volume acumulado no reservatório.

No AcquaNet, pode-se ordenar os elementos do sistema por meio de uma política de prioridades, na interface. Por meio da política de prioridades o modelo define em quais situações é preferível atender determinado elemento da rede em detrimento de outro.

\subsection{REDES NEURAIS}

O conceito de redes neurais artificiais (RNA) foi primeiramente introduzido por McCulloch e Pitts (1943) em seu modelo de funcionamento de um neurônio artificial. Entretanto, a técnica ganhou notoriedade e alcançou diversas áreas de engenharia a partir da década de 1980 com o avanço computacional (GOVINDARAJU e RAO, 2000). Redes neurais artificiais são sistemas inspirados no sistema nervoso de organismos biológicos, cujo objetivo é mimetizar o funcionamento do cérebro a partir da propagação de dados através de uma rede interconectada (CHANDRAMOULI e RAMAN, 2001).

Embora mais simples do que um cérebro biológico, as RNAs possuem características análogas, como o compartilhamento de informações por meio da distribuição massiva e paralela de unidades de neurônios individuais. Algumas características particulares das RNAs são a sua capacidade de aprendizado, podendo estendê-lo a outro conjunto de dados, e de armazenamento de informações (CANCELLIERE et al., 2002). Além disso as RNAs possuem flexibilidade quanto à não linearidade do problema, facilitam o reconhecimento e mapeamento de padrões, e após treinada, a rede possui certa tolerância a falhas (HAYKIN, 2008).

Os neurônios são as unidades fundamentais das redes neurais, e sua ativação ou inibição é regida pela configuração das sinapses, ou seja, pela interligação entre os demais elementos da rede e pelos seus respectivos pesos. Os neurônios são dispostos em camadas de entrada, de saída e por camadas ocultas, onde ocorre a grande parte dos cálculos (CANCELLIERE et al, 2002; HAYKIN, 2008). 
A arquitetura das RNAs pode ser determinada pelo seu algoritmo de resolução, mas em geral pode ser classificada em progressiva ou recursiva, com a presença de loops. A RNA progressiva pode ser em uma única camada, ou em múltiplas camadas (HAYKIN, 2008). Para construir um modelo de RNA é necessário definir o número de variáveis de input, de output, a quantidade de camadas ocultas, e o número de neurônios em cada camada. Este processo normalmente ocorre por tentativas de configurações distintas (CHANDRAMOULI e DEKA, 2005). Com poucos nós, a RNA tem dificuldade de reconhecer padrões mais complexos, entretanto, com muitas camadas e nós, a RNA tende a ter longo tempo de processamento e mais dificuldade em interpretar os padrões dos dados (JAIN et al, 2000).

A Figura 3.7 mostra um esquema genérico da configuração usual de uma RNA progressiva e em múltiplas camadas.

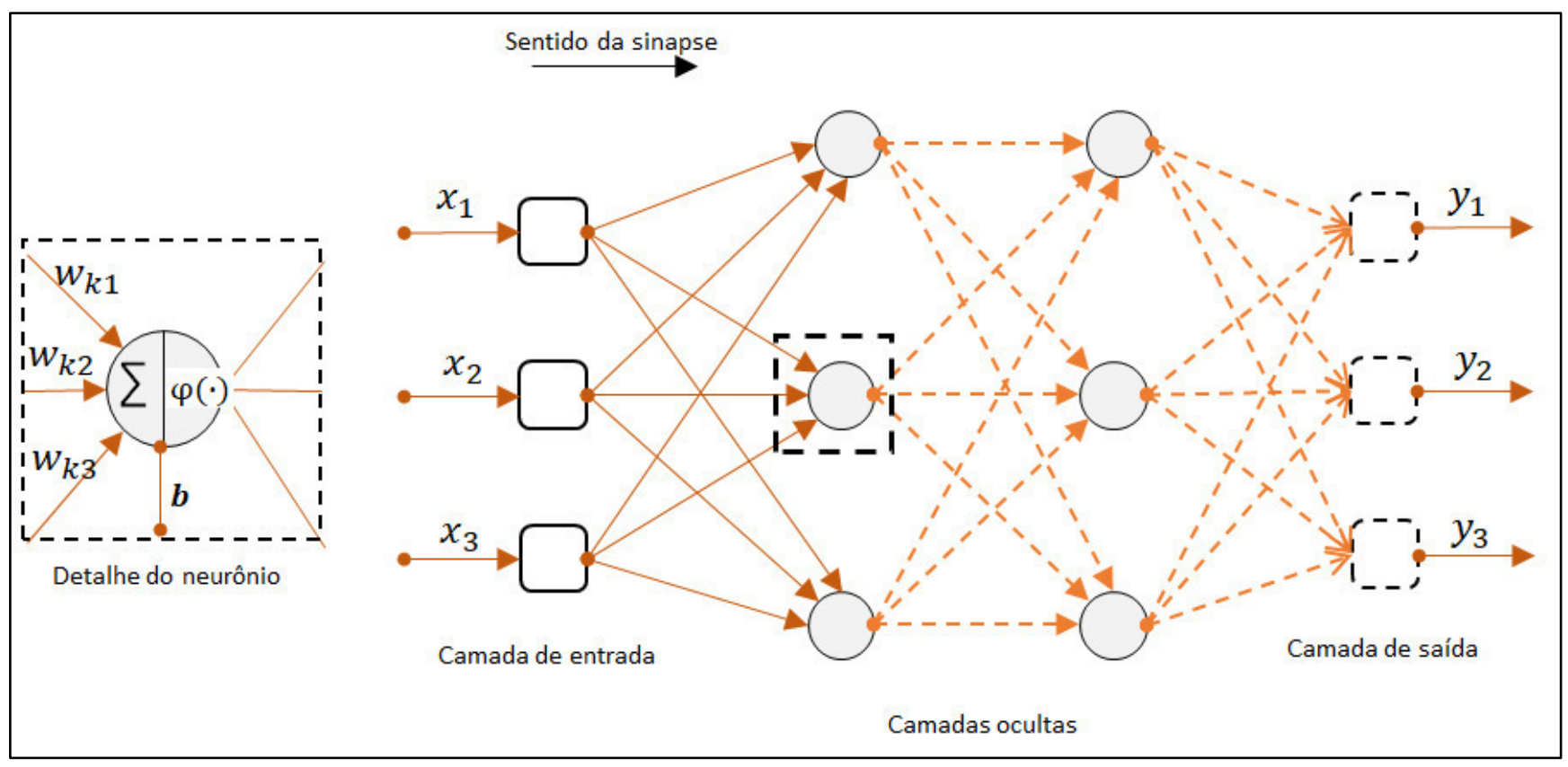

Figura 3.7 - Rede neural artificial progressiva em múltiplas camadas. Fonte: Adaptado de HAYKIN, 2008.

Onde:

- $\mathrm{x}_{1}, \mathrm{x}_{2}, \mathrm{x}_{3}-$ dados de entrada;

- y1, y2, y3 - dados de saída;

- $\quad$ wk1, wk2, wk3 - pesos das conexões entre os neurônios;

- $\mathrm{b}$ - bias, ou termo linear; 
- $\Sigma$ - junção somadora;

- $\phi(\cdot)$ - função de ativação;

Os pesos e o termo linear são os parâmetros ajustáveis da rede neural. O objetivo do termo linear é aumentar ou diminuir o efeito dos dados de entrada na ativação de determinado neurônio. A junção somadora representa na prática, a combinação linear dos dados de entrada da camada com os pesos das ligações, conforme a equação 3.9 :

$$
u_{k}=\sum_{j=1}^{m} w_{k} \cdot x_{i}
$$

Desta forma, a saída da rede neural pode ser escrita conforme a equação 3.10 :

$$
y_{k}=\varphi\left(u_{k}+b_{k}\right)
$$

A função de ativação $\phi(\cdot)$ define a saída local do neurônio na rede, e é normalmente utilizada com a finalidade de introduzir a não linearidade. Usualmente podem ser admitidos diversos tipos de funções de ativação a depender da configuração da rede, porém a função sigmóide (equação 3.11) é uma das mais utilizadas (HAYKIN, 2008).

$$
\varphi(x)=\frac{1}{1+e^{-x}}
$$

O processo de cálculo da RNA envolve uma etapa de treinamento supervisionado ou não, em que os dados iniciais são apresentados à rede. No treinamento supervisionado são considerados os pares de vetores de dados de entrada e saída, e a medida que os pesos das conexões se ajustam, são feitas comparações do erro entre o dado de saída obtido e o dado de saída desejado (PRIDDY e KELLER, 2005). 
Uma vez que a qualidade da rede neural depende dos dados que a alimentam, a seleção adequada deste conjunto é fundamental. Uma das técnicas de treinamento das RNAs é o algoritmo conhecido por backpropagation que tenta minimizar o erro quadrático entre os dados de saída e os dados utilizados para calibração da rede (CANCELLIERE et al, 2002).

Encontram-se significativas aplicações de modelos de RNAs na literatura com relação a análises de sistemas de reservatórios e modelos para gerar políticas operativas. Em aplicações para reservatórios, Jain et al (2000) descrevem que é usual admitir que os dados de entrada sejam combinações do volume inicial do reservatório com as afluências, e a camada de saída a vazão retirada do sistema.

Raman e Chandramouli (1996) aplicaram um modelo de PD associado à uma RNA para derivar regras operativas otimizadas para um reservatório indiano. A rede neural foi formulada a partir de uma camada de neurônios com função de ativação sigmoidal, e resolvida pelo algoritmo de backpropagation. A rede foi treinada a partir dos resultados otimizados da PD tendo como dados de entrada os volumes iniciais armazenados no reservatório, vazões naturais e demandas, e como dados de saída as retiradas otimizadas do reservatório. O desempenho da RNA foi analisado a partir de um modelo de simulação de um reservatório que reproduzisse seu comportamento.

Salas, Markus e Tokar (2000) utilizaram um modelo de RNA como alternativa para previsão de vazões em Julho, com base nas vazões de Junho do rio Frazer, no Colorado-EUA. Os autores utilizaram dados reais entre junho e julho de 1951 a 1970, dividida em duas sequências de 10 anos, para treinamento da rede e para validação. No mesmo estudo também foi proposta uma RNA para gerar um modelo de chuvavazão para o rio Little Patuxent, Maryland-EUA. A rede foi treinada com dados de precipitação de três anos, compondo uma configuração de ano médio seguido por ano seco e ano úmido, respectivamente 1979, 1980 e 1994. A rede foi então validada para a mesma configuração de umidade para os anos 1989, 1991 e 1992. Chandramouli e Raman (2001) aplicaram um modelo de rede neural associado à PD para analisar a operação de um sistema de três reservatórios conjugados de Tamil Nadu, na Índia.

Cancelliere et al. (2002) desenvolveram um modelo composto por PD associado à RNA para derivar vazões otimizadas mensais em um sistema de irrigação alimentado pelo reservatório Pozzilo, na Itália. Os autores utilizaram os resultados da PD disponíveis ao início de cada mês como base para o treinamento de seis RNAs. A 
PD do modelo foi calculada com o software CSUDP. A política de operação obtida foi então simulada em outro período de afluências para analisar seu desempenho.

Chandramouli e Deka (2005) apresentaram um sistema de suporte à decisão para operar um reservatório no sul da Índia. O SSD foi desenvolvido a partir de uma RNA treinada para obter retiradas otimizadas a partir das vazões afluentes ao reservatório. Duas configurações distintas para as RNAs foram analisadas, na primeira, os dados de entrada foram as vazões naturais e o volume inicial do reservatório por período considerado no estudo, e na segunda, os dados de entrada foram apenas as vazões naturais do período anterior. Apesar de o primeiro modelo ser mais eficiente, os autores concluíram que o segundo se apresentava como alternativa mais prática para planejamento da operação. 


\section{4. ÁREA DE ESTUdo}

A Região Metropolitana de São Paulo (RMSP) é composta por 39 municípios e possui mais de 20 milhões de habitantes. O fornecimento de água para a região é feito por meio de oito sistemas produtores sob operação da Companhia Saneamento Básico do Estado de São Paulo (SABESP): Cantareira, Guarapiranga, Alto Tietê, Rio Grande, Rio Claro, Alto e Baixo Cotia e Ribeirão da Estiva, que juntos e operando em situação de normalidade são capazes de fornecer mais de $75 \mathrm{~m}^{3} / \mathrm{s}$, conforme mostra a Tabela 4.1 .

Tabela 4.1 - Sistemas produtores da RMSP.

\begin{tabular}{ccc}
\hline Sistema & Mananciais & $\begin{array}{c}\text { Capacidade de } \\
\text { produção }\left(\mathrm{m}^{3} / \mathrm{s}\right)\end{array}$ \\
\hline Cantareira & $\begin{array}{c}\text { Jaguari-Jacareí, Cachoeira e Atibainha, Paiva } \\
\text { Castro e Águas Claras }\end{array}$ & 33,0 \\
\hline Guarapiranga & $\begin{array}{c}\text { Guarapiranga, transferências da Billings e rio } \\
\text { Capivari }\end{array}$ & 16,0 \\
\hline Alto Tietê & Taiaçupeba, Jundiaí, Biritiba-Mirim, Ponte & 15,0 \\
Rio Grande & Nova e Paraitinga & 4,8 \\
\hline São Lourenço & Cachoeira do França & 4,7 \\
\hline Rio Claro & Ribeirão do Campo & 4,0 \\
Alto Cotia & Pedro Beicht e Cachoeira da Graça & 1,3 \\
\hline Baixo Cotia & Rio Cotia & 1,1 \\
\hline Ribeirão da & Ribeirão da Estiva & 0,1 \\
Estiva & Cina & \\
\hline
\end{tabular}

Fonte: Adaptado de ANA (2010) e SABESP (2015).

Segundo a ANA (2014) entre 2012 e 2014 foram observadas alterações atípicas nos regimes de chuvas do país, com reduções significativas nos índices pluviométricos. Este fenômeno, cujas origens climáticas são incertas, causou impactos em setores voltados ao abastecimento de água, irrigação e geração de energia elétrica em diversas regiões, especialmente no semiárido brasileiro e nas regiões metropolitanas com maior demanda hídrica como São Paulo e Rio de Janeiro.

O Sistema Cantareira (SC), responsável pela produção de $44 \%$ da capacidade dos sistemas que atendem a RMSP, foi um dos que sofreu grandes impactos neste período. A situação comprometeu o abastecimento de água para cerca de 9 milhões de pessoas na Região Metropolitana de São Paulo (RMSP) durante dezessete meses 
e causou dificuldades para 3 milhões de pessoas que dependem da água a jusante do sistema, na bacia do Rio Piracicaba. Situações como esta, refletem a necessidade de aprimorar a operação de sistemas complexos de reservatórios para lidar com problemas dessa natureza.

\subsection{O SISTEMA CANTAREIRA}

O Sistema Cantareira é um dos maiores sistemas produtores de água do mundo, (WHATELY e CUNHA, 2007), capaz de fornecer $33 \mathrm{~m} / \mathrm{s}$ destinados ao abastecimento de aproximadamente 9 milhões de habitantes da RMSP distribuídos nas zonas norte, central, parte da leste e oeste da capital paulista e nos municípios de Franco da Rocha, Francisco Morato, Caieiras, Osasco, Carapicuíba e São Caetano do Sul, além de parte dos municípios de Guarulhos, Barueri, Taboão da Serra e Santo André. (SABESP, 2015).

O SC é um sistema composto por seis reservatórios, sete túneis, um canal, uma estação elevatória e uma ETA. Os reservatórios que compõe o sistema são o Jaguari, Jacareí, Cachoeira, Atibainha, Paiva Castro e Águas Claras. Os quatro primeiros funcionam em conjunto e desviam água de alguns rios na bacia hidrográfica do Rio Piracicaba, pertencente ao comitê de bacias PCJ, para o Rio Juqueri, na bacia do Alto Tietê, e de lá são captadas no reservatório de Paiva Castro. Em seguida as águas são bombeadas pela estação EESI para o reservatório de Águas Claras, de onde são conduzidas para tratamento na ETA Guaraú, uma das maiores estações de tratamento da América Latina. (ANA, 2014). 


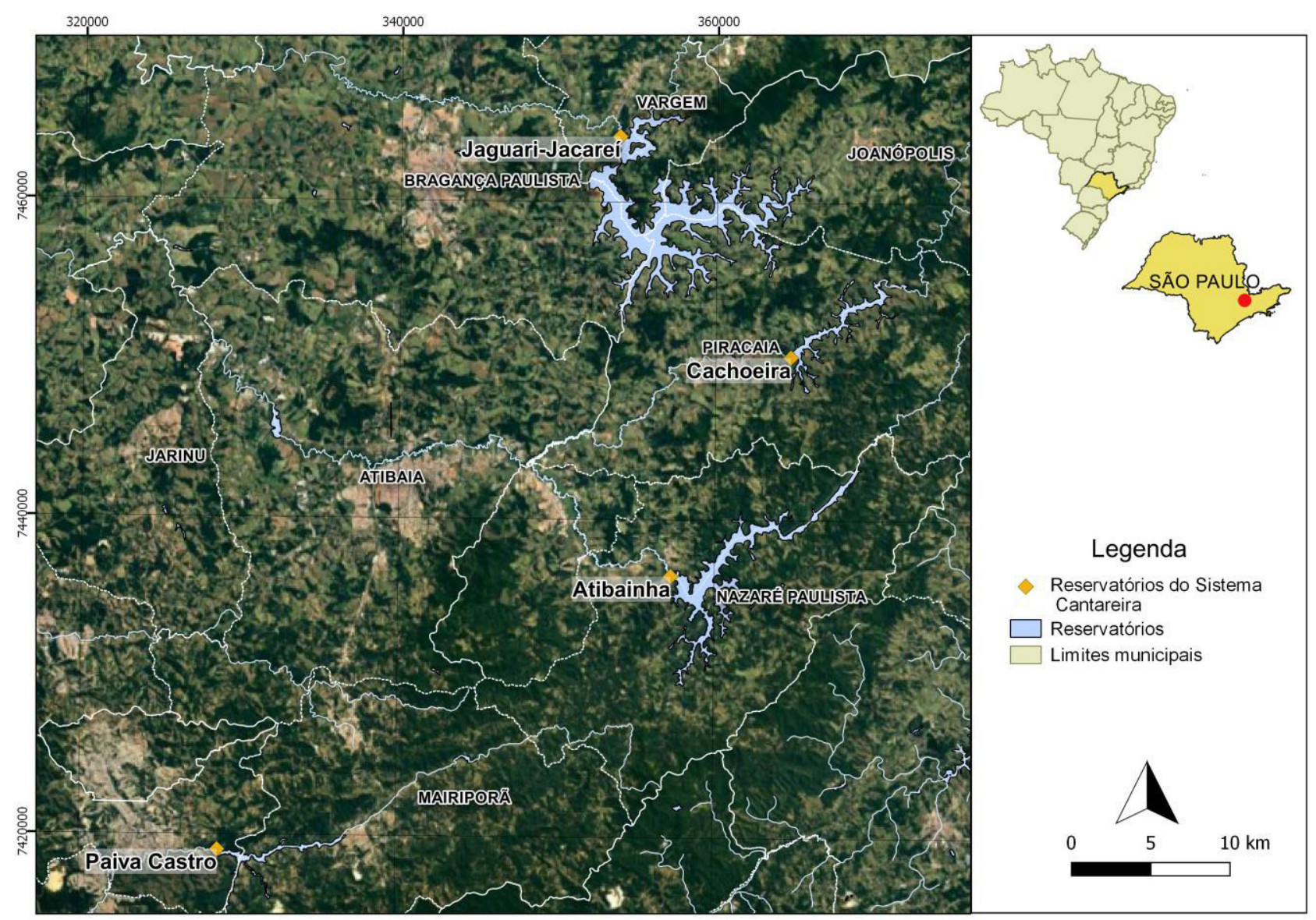

Figura 4.1 - Localização do Sistema Cantareira

Os reservatórios Jaguari e Jacareí funcionam como um único conjunto devido à ligação por um canal aberto, e é ligado ao reservatório Cachoeira pelo túnel 7. Os túneis 6 e 5 interligam os reservatórios Cachoeira e Atibainha, e Atibainha e Paiva Castro, respectivamente.

A Figura 4.2 apresenta o perfil hidráulico esquematizado do SC mostrando os reservatórios e túneis que o compõe. 


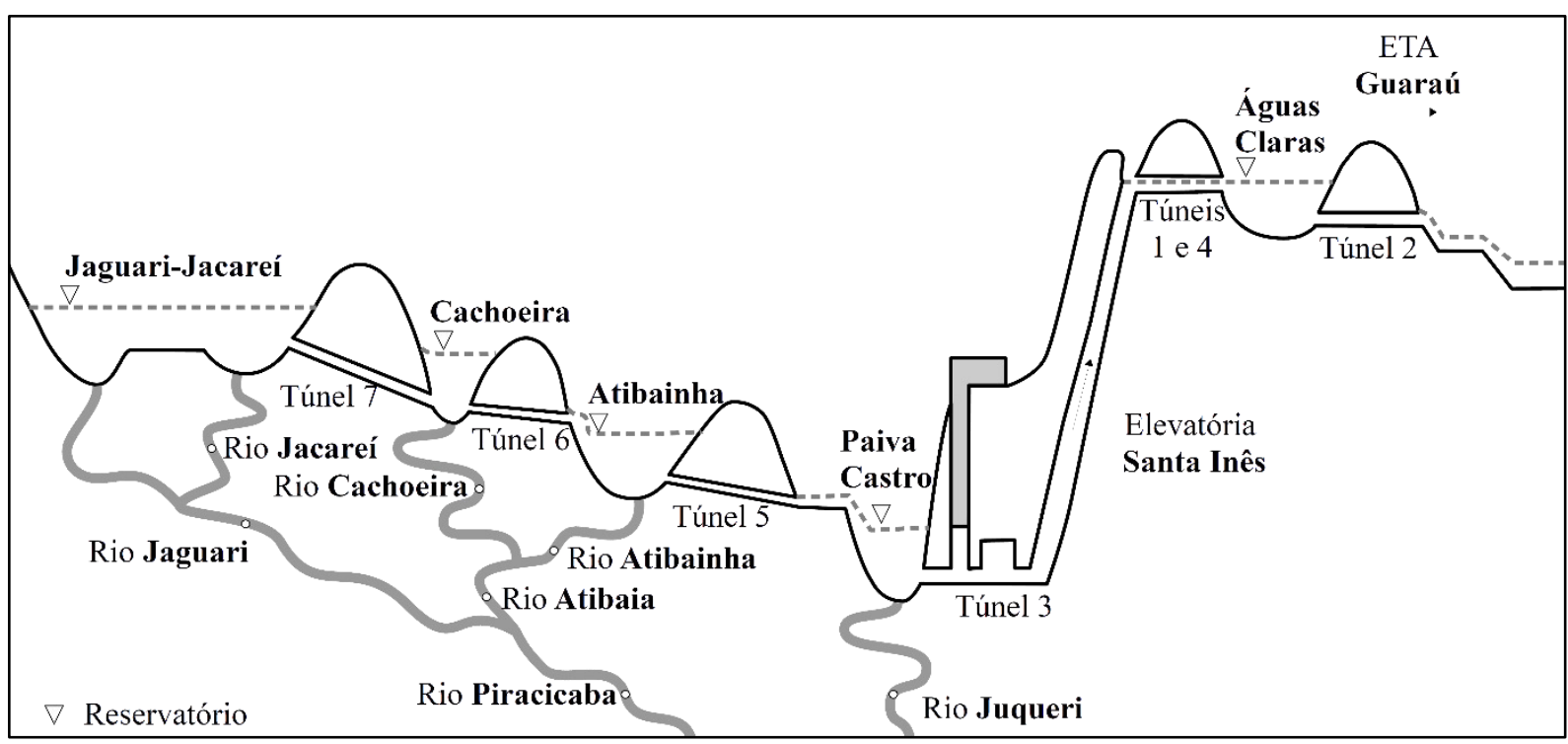

Figura 4.2 - Representação esquemática do Sistema Cantareira. Fonte: Adaptado de ANA (2014).

As principais características dos componentes do sistema são mostradas a seguir na Tabela 4.2 e Tabela 4.3.

Tabela 4.2 - Resumo das características dos reservatórios do Sistema Cantareira.

\begin{tabular}{llcccll}
\hline Reservatório & $\begin{array}{l}\text { Início } \\
\text { Operação }\end{array}$ & $\begin{array}{c}\text { Volume } \\
\text { útil } \\
\left(\mathbf{h m}^{3}\right)\end{array}$ & $\begin{array}{c}\text { Volume } \\
\mathbf{m o r t o} \\
\left.\mathbf{( h m}^{3}\right)\end{array}$ & $\begin{array}{c}\text { Volume } \\
\text { total } \\
\left.\mathbf{( h m}^{3}\right)\end{array}$ & $\begin{array}{l}\text { Vertedor de } \\
\text { superfície }\end{array}$ & $\begin{array}{l}\text { Descarregador } \\
\text { de fundo }\end{array}$ \\
\hline $\begin{array}{l}\text { Jaguari - } \\
\text { Jacareí }\end{array}$ & Maio/1982 & 808.12 & 239.43 & 1047.55 & Creager & $\begin{array}{l}\text { Válvulas } \\
\text { dispersoras }\end{array}$ \\
\hline Cachoeira & Novembro/1974 & 69.75 & 46.81 & 116.56 & Tulipa & Comporta plana \\
\hline Atibainha & Fevereiro/1975 & 95.26 & 194.93 & 290.19 & Tulipa & Comporta plana \\
\hline Paiva Castro & Maio/1973 & 7.61 & 25.33 & 32.94 & $\begin{array}{l}\text { Creager e } \\
\text { comporta } \\
\text { Setor }\end{array}$ & $\begin{array}{l}\text { Válvula borboleta } \\
\text { e válvula esfera }\end{array}$ \\
\hline
\end{tabular}

Fonte: Adaptado de ANA e DAEE (2016).

Tabela 4.3 - Resumo das características dos túneis e canais do Sistema Cantareira.

\begin{tabular}{|c|c|c|c|c|}
\hline \multicolumn{2}{|r|}{ Estrutura } & Tomada d'água & $\begin{array}{l}\text { Extensão } \\
(\mathrm{m})\end{array}$ & $\begin{array}{c}\text { Capacidade } \\
\left(\mathrm{m}^{3} / \mathrm{s}\right)\end{array}$ \\
\hline $\begin{array}{l}\text { Canal de } \\
\text { Ligação } \\
\text { Jaguari-Jacareí }\end{array}$ & $\begin{array}{l}\text { Canal aberto trapezoidal } \\
\text { com trecho escavado em } \\
\text { rocha }\end{array}$ & $\begin{array}{l}\text { Vertedor de } 4,00 \mathrm{~m} \text { de altura } \\
\text { e } 15,00 \mathrm{~m} \text { de crista }\end{array}$ & 670 & ( \\
\hline Túnel 5 & $\begin{array}{l}\text { Túnel escavado em rocha e } \\
\text { revestido de concreto }\end{array}$ & $\begin{array}{l}\text { Comporta setor } 2,61 \times 3.37 \\
(\mathrm{~m}), \text { operada localmente }\end{array}$ & 9840 & 35 \\
\hline Túnel 6 & Túnel escavado em rocha & $\begin{array}{l}\text { Comporta setor } 2,63 \times 2,89 \\
(\mathrm{~m}), \text { operada localmente }\end{array}$ & 4769 & 35 \\
\hline Túnel 7 & $\begin{array}{l}\text { Túnel escavado em rocha e } \\
\text { revestido de concreto }\end{array}$ & $\begin{array}{l}\text { Torre de concreto com } 3 \\
\text { pares de comportas de } \\
1,50 \times 8,00(\mathrm{~m})\end{array}$ & 5885 & 35 \\
\hline
\end{tabular}

Fonte: Adaptado de ANA e DAEE (2016). 
O reservatório Paiva Castro é ligado à estação EESI por meio do túnel 3, com extensão total de $994 \mathrm{~m}$. A EESI opera com 3 bombas e uma de reserva, implantadas a cerca de $70 \mathrm{~m}$ abaixo da superfície, e com capacidade nominal de $33 \mathrm{~m} / \mathrm{s}$. Os túneis 1 e 4, com extensão de 1184 m, fazem a ligação da elevatória com o reservatório Águas Claras. Este, com capacidade de $0,76 \mathrm{hm}^{3}$, tem a finalidade de manter o fluxo contínuo de água para a ETA Guaraú por meio do túnel 2, que possui extensão total de $4878 \mathrm{~m}$. Os túneis 1, 2, 3 e 4 possuem capacidade nominal de $33 \mathrm{~m} 3 / \mathrm{s}$. (ANA e DAEE, 2016).

\subsubsection{Operação do Sistema Cantareira}

A outorga para operação do sistema Cantareira foi concedida à SABESP pela Portaria № 750 de 08 de agosto de 1974, do Ministério das Minas e Energia (MME), autorizando derivação de até $33 \mathrm{~m} 3 / \mathrm{s}$ por um período de 30 anos. Em 2004, diante da finalização do prazo da vigência estabelecida foram publicadas as resoluções conjuntas ANA/DAEE ํo. 428 e no 429 (04 de agosto de 2004), a primeira propõe condições de operação para os reservatórios Jaguari-Jacareí, Cachoeira e Atibainha. A segunda estabeleceu subsídios para análise de pedidos de outorga, e delegou competência para emissão de outorgas de direito de uso de recursos hídricos de domínio da União no âmbito das Bacias Hidrográficas dos Rios Piracicaba, Capivari e Jundiaí. Dessa forma, a renovação da outorga do Sistema Cantareira passou a ser de competência do DAEE (ANA, 2014).

A Portaria DAEE №. 1213, de 06 de agosto de 2004 renovou o direito de outorga para a SABESP com prazo de vigência de 10 anos, estabelecendo que o SC fosse operado de forma integrada a partir de um reservatório equivalente composto pelos reservatórios Jaguari-Jacareí, Cachoeira e Atibainha. O documento estipulou uma retirada média mensal do sistema equivalente de no máximo $31 \mathrm{~m} 3 / \mathrm{s}$ para a RMSP e de $5 \mathrm{~m}^{3} / \mathrm{s}$ para as bacias PCJ, e o limite de $33 \mathrm{~m}^{3} / \mathrm{s}$ de retirada pela EESI (ANA e DAEE, 2016). A dinâmica operacional seguiria uma rotina mensal, em que a SABESP comunicaria às agências reguladoras as vazões médias pretendidas no mês subsequente. Então, a cada início de período a ANA e o DAEE emitiriam um 
comunicado conjunto deliberando sobre a vazão a ser derivada para a RMSP e para a bacia do PCJ (SABESP, 2014).

Entre os anos de 2009 e 2010, devido a eventos de chuvas intensas e persistentes na região sudeste, houve a necessidade de novos estudos sobre as regras operacionais dos reservatórios para controle de cheias. A Resolução Conjunta ANA/DAEE nํ. 614 de 09 de agosto de 2010 estabelece as condições de operação dos reservatórios do Sistema Cantareira entre os meses entre outubro e junho, quando a Sabesp deve verificar a necessidade de alocação de volumes de espera (ANA e DAEE, 2016).

Entre os anos de 2013 e 2014 o SC enfrentou um período de baixas vazões afluentes, resultando na queda dos volumes acumulados sistema. Diante da proximidade do prazo de vencimento da outorga de 2004, foi elaborada a Resolução conjunta ANA/DAEE ํํ 910, de 7 de julho de 2014, que prorrogou seu prazo de sua vigência até outubro de 2015. Considerando a complexidade do tema e a necessidade de novos estudos e estratégias de operação do sistema, a renovação da outorga do SC foi novamente adiada para maio de 2017 por meio da Resolução Conjunta ANA/DAEE no. 1200, de 22 de outubro de 2015 (ANA, 2014; ANA e DAEE, 2016).

Em 2017 foram promulgadas as resoluções conjuntas ANA/DAEE no 925 e 926 de 29 de maio de 2017. A resolução $\cong 925$ dispõe sobre as condições de operação dos reservatórios do sistema Cantareira, e estabelece a regra de operação baseada em faixas de disponibilidade de volume útil acumulado do reservatório equivalente. $\mathrm{O}$ reservatório equivalente (RE) considera os reservatórios Jaguari-Jacareí, Cachoeira, Atibainha e Paiva Castro.

Esta resolução estabelece ainda três pontos de controle para medição de vazões; um no rio Jaguari medido em Buenópolis, um no rio Atibaia medido em Valinhos, e o outro na estação elevatória de Santa Inês para atendimento da RMSP.

A resolução conjunta ANA/DAEE n 926/2017, mencionada, renovou a outorga do SC para a Sabesp por 10 anos, a partir das diretrizes promulgadas na resolução no 925/2017. O resumo da regra de operação vigente do Sistema Cantareira é mostrado na Tabela 4.4 . 
Tabela 4.4 - Resumo da regra operativa vigente do Sistema Cantareira.

\begin{tabular}{c|c|ccc}
\hline \multicolumn{5}{c}{ Vazões requeridas $\left(\mathrm{m}^{3} / \mathrm{s}\right)$} \\
Faixa & $\%$ volume & RMSP & Buenópolis & Valinhos \\
\hline Faixa 1 & $0-20 \%$ & 15,50 & 2 & $10 / 10^{*}$ \\
\hdashline Faixa 2 & $20 \%-30 \%$ & 23 & 2 & $13 / 10^{*}$ \\
\hline Faixa 3 & $30 \%-40 \%$ & 27 & 2 & $13 / 10^{*}$ \\
\hdashline Faixa 4 & $40 \%-60 \%$ & 31 & $2,5 / 2^{*}$ & $15 / 10^{*}$ \\
\hline Faixa 5 & $60 \%-100 \%$ & 33 & $2,5 / 2^{*}$ & $15 / 10^{*}$ \\
\hline *Demanda requerida para o período seco. &
\end{tabular}

Fonte: Adaptado de ANA e DAEE (2017).

A regra define valores de demandas requeridas nos três pontos de controle, em RMSP, Valinhos e Buenópolis. A diretriz principal da regra baseia-se na porcentagem de volume útil acumulada no RE para definir valores requeridos para as demandas. Para as demandas nos pontos de controle em Buenópolis e Valinhos alguns dos valores foram divididos entre período seco ou úmido de afluências. O período seco corresponde aos meses entre junho e novembro, e o úmido, entre dezembro e maio.

\subsubsection{A "crise hídrica"}

Whately (2006) faz um panorama histórico da construção dos reservatórios do sistema, explicando que' houve forte estiagem no período de 1998 a 2004. Em 2003 o sistema atingiu níveis alarmantes de armazenamento que comprometeram o abastecimento público. Em meados de 2014, eventos semelhantes de grande magnitude causaram o esgotamento do volume útil do SC, ganhando destaque em mídia nacional.

Entre outubro de 2013 a março de 2014, houve significativa redução no volume de precipitação nas bacias dos Rios Piracicaba, Capivari e Jundiaí, o que ocasionou redução das vazões afluentes médias mensais aos reservatórios do Sistema Cantareira, afetando diretamente o volume de água armazenado nos reservatórios (ANA, 2014). Até então, a operação do sistema tinha como referência o biênio 19531954 para períodos secos (SABESP, 2015a). 
A Figura 4.3 compara as vazões afluentes médias mensais do reservatório equivalente do SC, considerando os reservatórios Jaguari-Jacareí, Cachoeira, Atibainha e Paiva Castro, observadas nos períodos de 1930 a 2015, 1953 a 1954 e 2014 a 2015. No biênio 2013-2014 observou-se a média de vazão afluente anual de $17,0 \mathrm{~m}^{3} / \mathrm{s}$, que corresponde a $60 \%$ do valor médio anual observado para o biênio 1953$1954(28,3 \mathrm{~m} / \mathrm{s})$ e a $39 \%$ da média anual histórica $\left(43,5 \mathrm{~m}^{3} / \mathrm{s}\right)$.

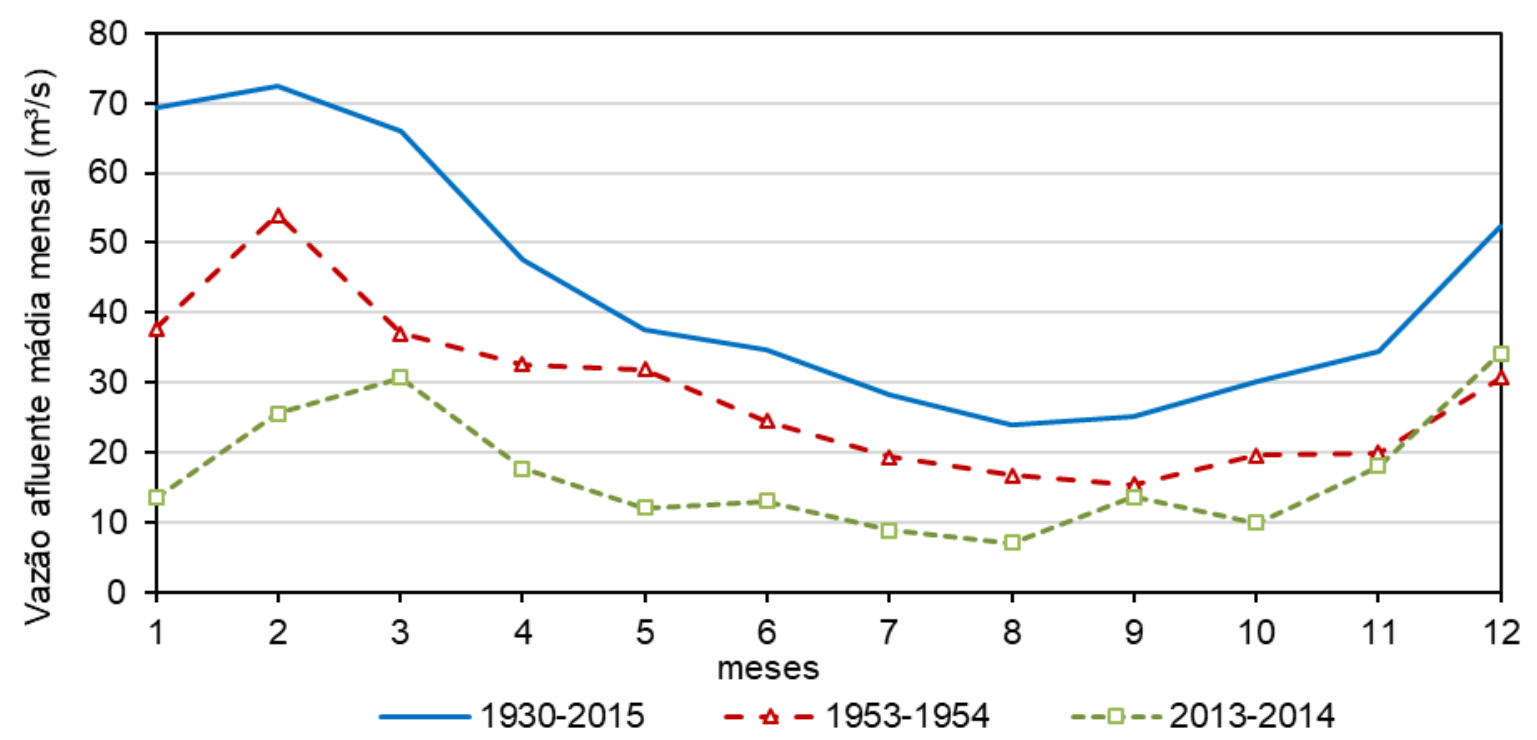

Figura 4.3 - Vazões afluentes médias ao RE do SC nos períodos de 1930 a 2015, 1953 a 1954 e de 2013 a 2014. Fonte: Adaptado de ANA (2014).

Segundo relatório de ações contingências da SABESP (2015a) a fim de minimizar os impactos no atendimento à população, foram colocadas em prática diversas ações institucionais e estratégias. Algumas delas são sumarizadas a seguir (SABESP, 2015a, 2015b):

- Ações institucionais - campanhas de comunicação nas principais mídias, filmes televisivos, palestras e treinamentos sobre economia de água.

- Gestão de consumo dos clientes - consistiu em um programa de bônus para incentivar a redução de consumo da população iniciado em fevereiro de 2014.

- Intensificação do programa de combate às perdas na rede, cujas principais ações possibilitaram expansão das ações já executadas e redução do tempo médio de resposta a serviços de reparos. 
- Reduções de pressão na rede de distribuição para valores menores do que os previstos por regulamentações técnicas, realizadas em horários e regiões préestabelecidas.

- Utilização das reservas técnicas - foram executadas obras emergenciais para aproveitamento dos volumes mortos das represas Jaguari-Jacareí e Atibainha, e a partir de maio de 2014 a chamada reserva técnica I começou a ser utilizada com um volume disponível de $182,5 \mathrm{hm}^{3}$. Em outubro de 2014 a chamada reserva técnica II, correspondente a segunda cota de volume morto do reservatório Jaguari-Jacareí entrou em utilização agregando $105 \mathrm{hm}^{3}$ ao sistema.

As obras tiveram sua execução considerada em tempo recorde considerando as liberações dos órgãos ambientais competentes, e consistiram em conjuntos de tubulações totalizando mais de 3 quilômetros de tubulações e 17 bombas fixadas em flutuadores.

- Transferência de vazões de outros sistemas produtores - intervenções e obras foram realizadas entre 2014 e 2015 a fim de possibilitar transferência de vazões provenientes dos sistemas produtores Alto Tietê, Guarapiranga, Rio Claro e Rio Grande para o sistema Cantareira.

- Ampliação de vazões - consistiram em intervenções emergenciais para aumento da capacidade de acumulação/regularização dos demais sistemas produtores. Entre as principais obras desta natureza destacam-se: ampliação da capacidade de tratamento do Guarapiranga (adição de $2 \mathrm{~m} 3 / \mathrm{s}$ ) e do sistema Rio Grande (adição de $0,7 \mathrm{~m}^{3} / \mathrm{s}$ ), interligação entre as represas Billings e Taiaçupeba para transferência de $4 \mathrm{~m} 3 / \mathrm{s}$, ampliação da capacidade de transferência da represa Billings para a represa do Guarapiranga (em $4 \mathrm{~m}^{3} / \mathrm{s}$ ), interligação entre os reservatórios Jaguari e Atibainha para transferência de até $5 \mathrm{~m}^{3} / \mathrm{s}$. 


\section{METODOLOGIA}

O desenvolvimento deste trabalho ocorreu em três etapas. Na primeira etapa foi elaborado um modelo de PD determinística para otimizar uma série de vazões fornecidas. Na segunda etapa foram elaboradas dois modelos de rede neural artificial, o primeiro para definir políticas de prioridades para calibração do AcquaNet, e o segundo para definir as demandas otimizadas a partir dos resultados da PD, com a finalidade de compor regras operativas para o SC. Na terceira etapa as regras obtidas foram simuladas para o período total de vazões afluentes (1930 - 2017).

A fim de se obter regras operativas práticas, que possam ser comparáveis com a atual política de operação do Sistema Cantareira, admitiu-se como hipótese 4 configurações distintas de faixas de operação, a partir das quais procedeu-se a metodologia apresentada. A operação por faixas é uma maneira de estabelecer controle das retiradas de acordo com o volume armazenado no sistema, e a retirada deve diminuir de acordo com o esvaziamento do RE. Esta estratégia de operação tem sido uma tendência para o controle do SC desde a primeira outorga.

A Figura 5.1 sintetiza a metodologia. As particularidades da formulação e os respectivos parâmetros são descritos nas seções seguintes. 
$\begin{array}{lll}\text { Etapas } & \text { Mntrada } & \text { Saída }\end{array}$

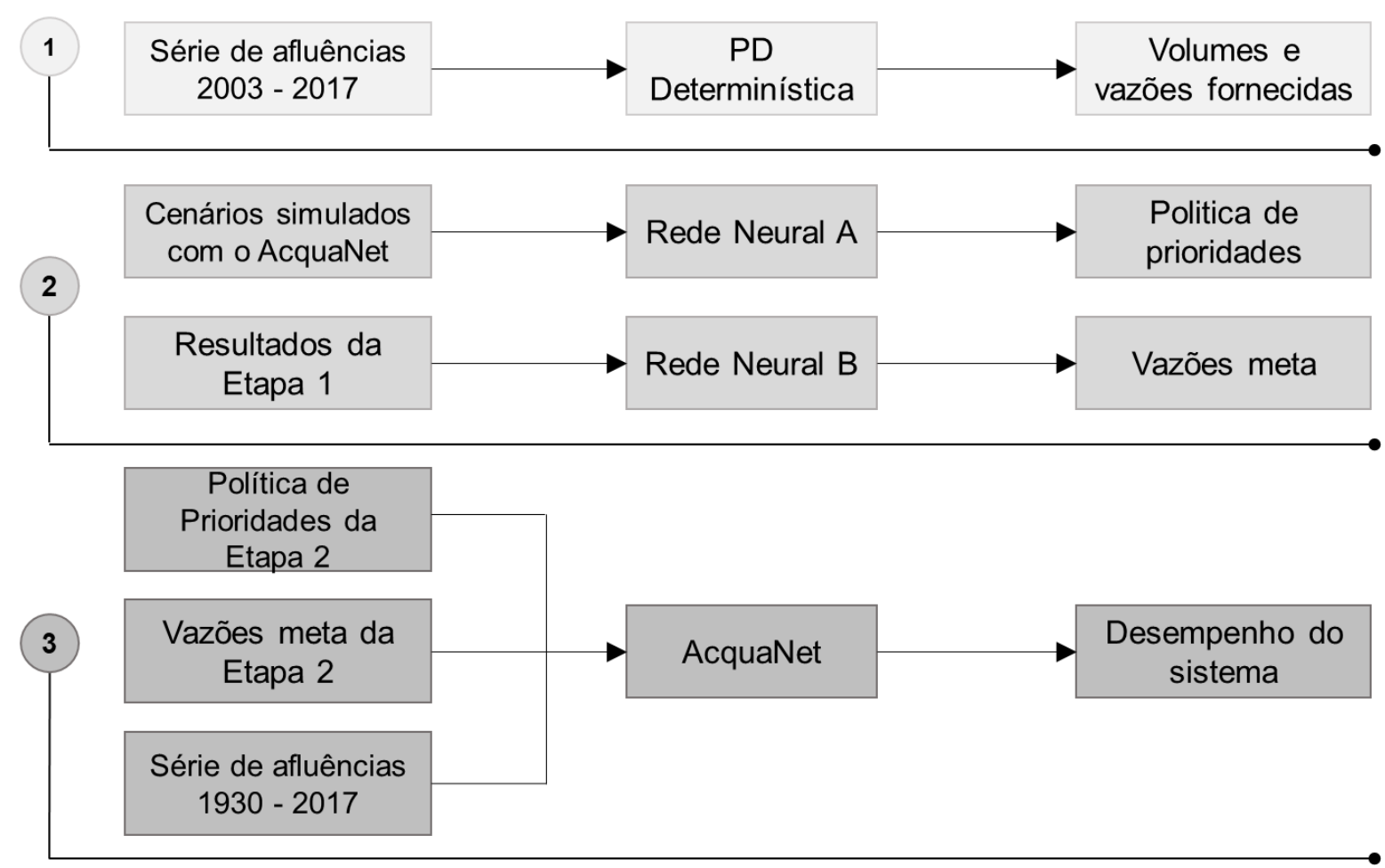

Figura 5.1 - Fluxograma da metodologia apresentada.

\subsection{ETAPA 1 - PROGRAMAÇÃO DINÂMICA}

A primeira etapa consistiu na otimização do SC por meio da PD determinística. Como dado de entrada, foi selecionada uma série de vazões naturais de 15 anos, entre os anos de 2003 a 2017, que contém o período crítico entre os anos 2013 e 2014.

O SC foi representado em um único reservatório equivalente $(\mathrm{RE})$ considerando os reservatórios Jaguari-Jacareí, Cachoeira, Atibainha e Paiva Castro. Três variáveis de decisão fornecem as descargas do sistema representando a demanda para a RMSP, e os dois pontos de controle de vazões medidas em Buenópolis e Valinhos, que também dispõem de vazões de contribuição das áreas intermediárias correspondentes. A Figura 5.2 mostra o esquema da rede de fluxo do RE com as vazões afluentes, os pontos de controle e as variáveis de decisão. 


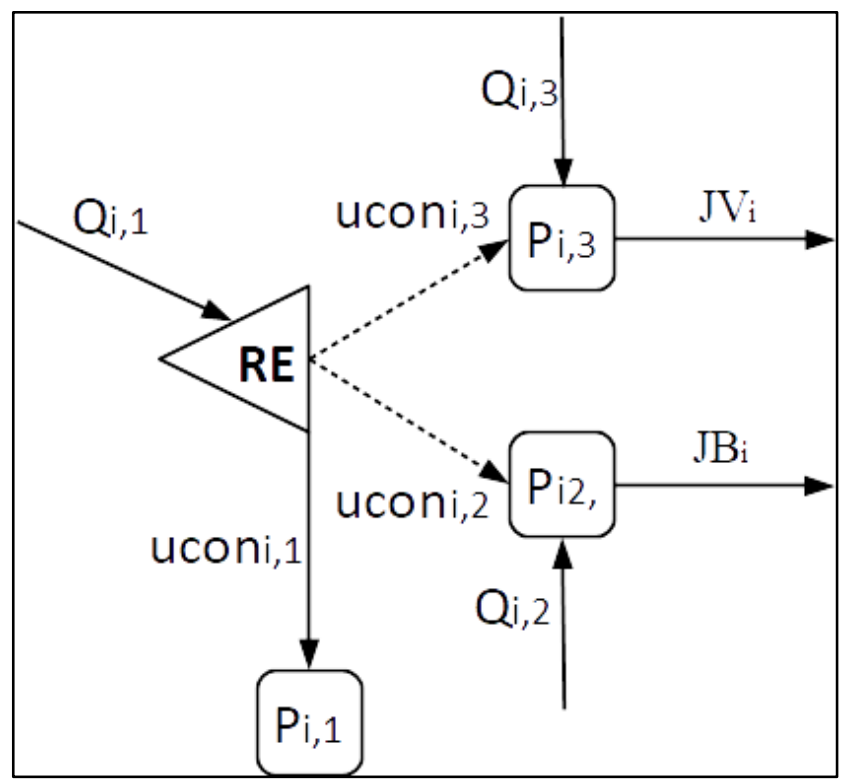

Figura 5.2 - Rede de fluxo do SC com reservatório equivalente.

Onde:

- i - estágio (mês);

- j - indicador da variável de decisão, com valores iguais a 1, 2 ou 3, representando respectivamente RE, Buenópolis e Valinhos;

- $\mathrm{RE}_{\mathrm{i}}\left(\mathrm{hm}^{3}\right)$ - reservatório equivalente do Sistema Cantareira;

- $\mathrm{P}_{\mathrm{i}, 1}\left(\mathrm{~m}^{3} / \mathrm{s}\right)$ - demanda da RMSP;

- $\mathrm{P}_{\mathrm{i}, 2}\left(\mathrm{~m}^{3} / \mathrm{s}\right)$ - ponto de controle para medições de vazão em Buenópolis, no rio Jaguari;

- $\mathrm{P}_{\mathrm{i}, 3}\left(\mathrm{~m}^{3} / \mathrm{s}\right)$ - ponto de controle para medições de vazão em Valinhos, no rio Atibaia;

- $Q_{i, 1}, Q_{i, 2}$ e $Q_{i, 3}\left(m^{3} / s\right)$ - vazões naturais do ponto de controle no RE, em Buenópolis e em Valinhos, respectivamente;

- ucon $_{\mathrm{i}, 1}$, uconi,2 e uconi,3 $\left(\mathrm{hm}^{3}\right)$ - descargas para os pontos de controle RMSP, Buenópolis, e Valinhos respectivamente;

- $\mathrm{JV}_{\mathrm{i}}$ e $\mathrm{JB}$ i $\left(\mathrm{m}^{3} / \mathrm{s}\right)$ - as vazões totais ou de jusante que passam pelos pontos de controle Valinhos e Buenópolis, respectivamente.

\section{- Função Objetivo}

A função objetivo é expressa em termos do atendimento às demandas do sistema, penalizando majoritariamente o não atendimento à RMSP $\left(\mathrm{P}_{\mathrm{i}, 3}\right)$. 


$$
F_{o b j}=\min \left\{\sum_{i=1}^{T} \sum_{j=1}^{3}\left(K \cdot \text { ucon }_{i, j}-P_{i, j} \cdot 2,628\right)^{2}\right\}
$$

Onde:

- T - limite superior do estágio (mês);

- $\mathrm{K}$ - fator de penalidade, sendo:

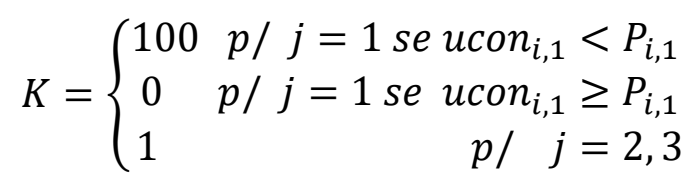

\section{- Função de transformação de estado}

$$
\begin{aligned}
& \text { ucon }_{i, 3}=R E_{i}-R E_{i+1}+Q_{i, 1} \cdot 2.628-\text { ucon }_{i, 2}-\text { ucon }_{i, 3} \\
& J B_{i}=Q_{i, 2} \cdot 2.628+\text { ucon }_{i, 2} \\
& J V_{i}=Q_{i, 3} \cdot 2.628+\text { ucon }_{i, 3}
\end{aligned}
$$

\section{- Restrições}

$$
\begin{aligned}
& R E_{i, \min } \leq R E_{i} \leq R E_{i, \max } \\
& P_{i, j} \geq P_{i, j, \min } \quad p / j=2,3 \\
& \sum_{j=1}^{3} \text { ucon }_{i, j} \leq R E_{i}+Q_{i, 1} \\
& \text { ucon }_{i, j, \min } \leq \operatorname{ucon}_{i, j} \leq \text { ucon }_{i, j, \max }
\end{aligned}
$$

Onde:

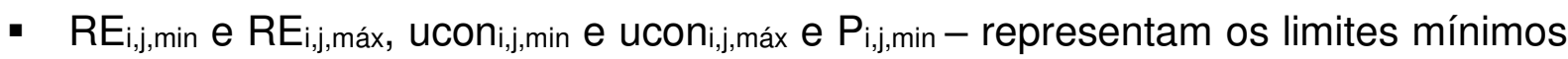
e máximos para a variável de estado e de decisão, e o limite mínimo para a descarga para os pontos de controle respectivamente. Estes valores, 
apresentados na Tabela 5.1 foram fornecidos manualmente através da interface do CSUDP.

Tabela 5.1 - Volumes do reservatório equivalente e limites das restrições adotadas no modelo.

\begin{tabular}{|c|c|c|c|}
\hline Volume do RE (hm³) & Inicial & Mín & Máx \\
\hline Volume útil - meses secos & & 0 & 981.56 \\
\hline Volume útil - meses chuvosos & & 0 & 942.30 \\
\hline Estado inicial (jan/2003) & 330 & & \\
\hline Demandas $\left(\mathrm{m}^{3} / \mathrm{s}\right)$ & Requerida & Mín & Máx \\
\hline Buenópolis $\left(\mathrm{P}_{\mathrm{i}, 1}\right)$ & 2.5 & 0.25 & 50 \\
\hline Valinhos $\left(\mathrm{P}_{\mathrm{i}, 2}\right)$ & 15.0 & 0.50 & 100 \\
\hline $\operatorname{RMSP}\left(\mathrm{P}_{\mathrm{i}, 3}\right)$ & 33.0 & & \\
\hline Variáveis de decisão $\left(\mathrm{m}^{3} / \mathrm{s}\right)$ & & Mín & Máx \\
\hline ucon $_{\mathrm{i}, 1}$ & & 0.25 & 50 \\
\hline ucon $_{\mathrm{i}, 2}$ & & 0.50 & 100 \\
\hline ucon $_{\mathrm{i}, 3}$ & & 0 & 33 \\
\hline
\end{tabular}

Os limites máximos das restrições da equação 5.6 consideraram a reserva de $4 \%$ do volume útil para o controle de cheias entre os meses chuvosos, (outubro a abril). Para as variáveis referentes aos pontos de controle, na equação 5.7 , os limites mínimos correspondem às demandas mínimas conforme a Tabela 5.1, e para os limites máximos foram consideradas três vezes as respectivas vazões requeridas, para permitir vertimento caso haja. Os limites das variáveis de decisão foram considerados constantes.

Os dados de entrada dos modelos de PD são as vazões afluentes, as restrições de capacidade máxima e mínima dos reservatórios, as demandas ou descargas a serem atendidas pelo sistema, os limites para as variáveis de decisão, e a discretização das variáveis de estado e de decisão.

O modelo considera 180 estágios (i), que representam os meses entre janeiro de 2003 a dezembro de 2017, mostradas na Figura 5.3 e na Figura 5.4. 


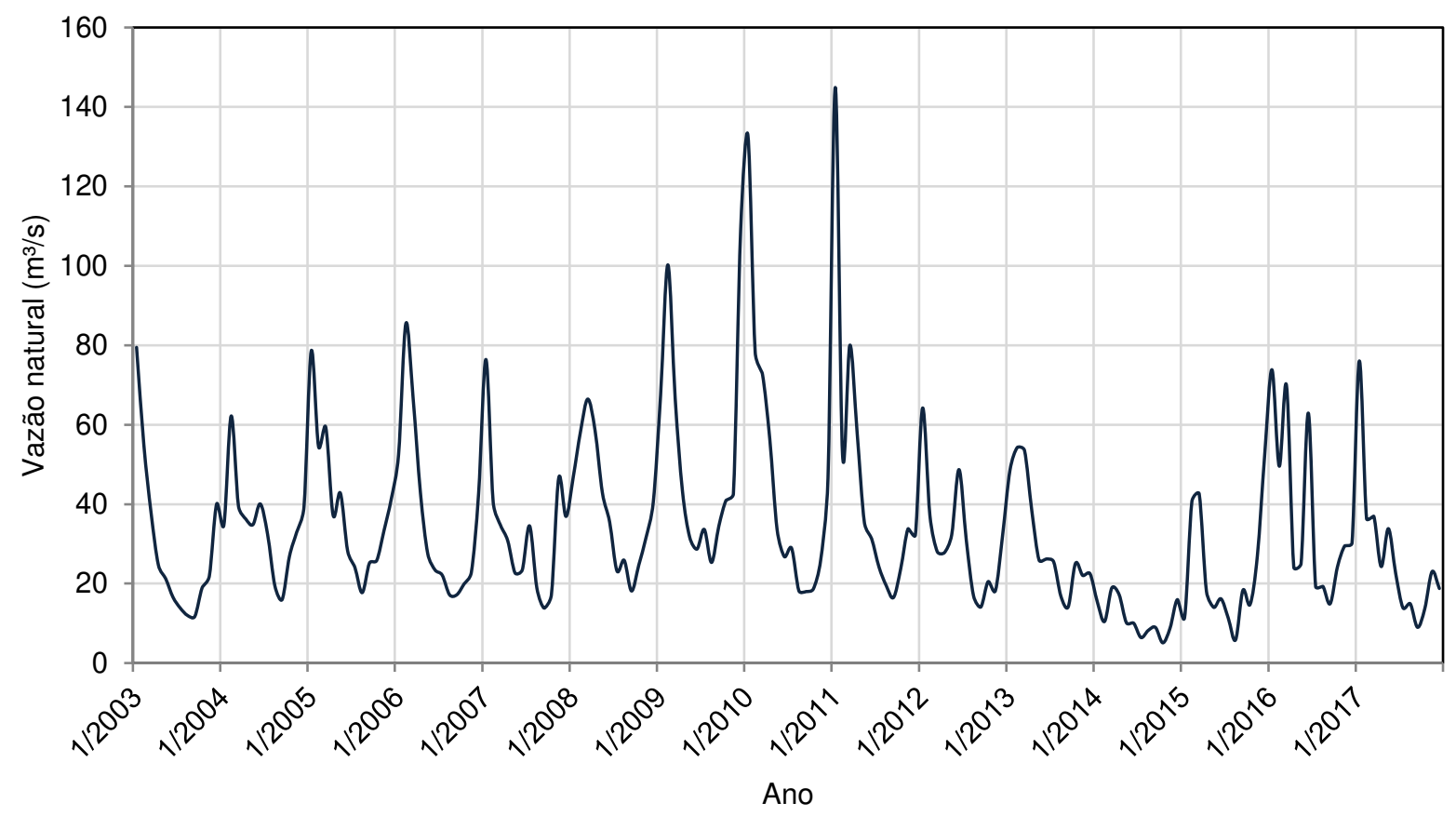

Figura 5.3 - Vazões médias mensais afluentes ao reservatório equivalente do SC de janeiro/2003 a dezembro/2017.

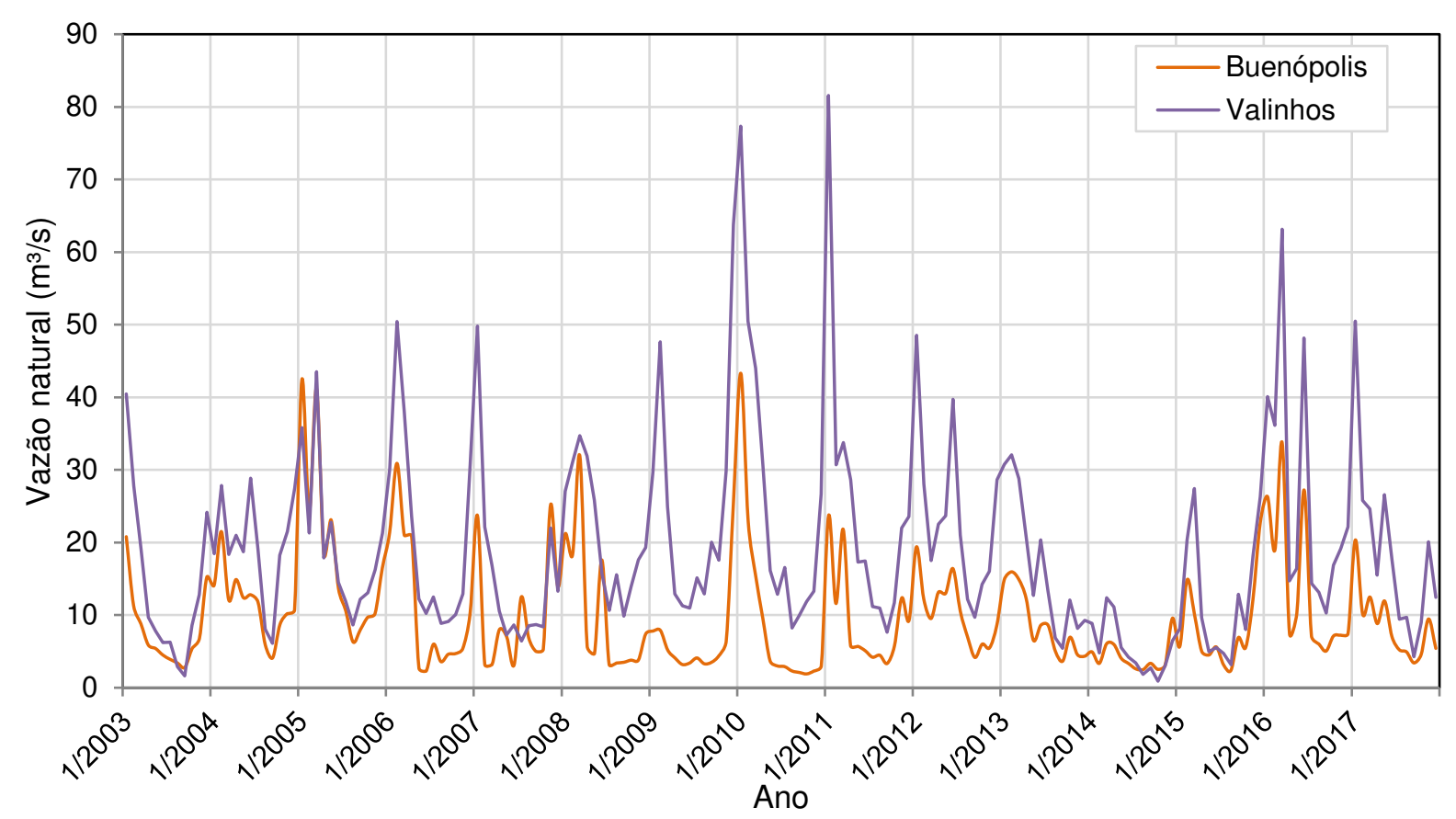

Figura 5.4 - Vazões médias mensais afluentes a Buenópolis e Valinhos de janeiro/2003 a dezembro/2017.

As vazões médias afluentes e os valores das demandas requeridas foram fornecidas ao software CSUDP por meio da função especial própria do software que permite a leitura de dados em um arquivo externo de texto. Os limites para as variáveis 
de estado e de decisão são colocados manualmente através da interface do programa para cada estágio. Como resultados o CSUDP gera os estados finais de armazenamento do RE em cada estágio e as vazões liberadas para as três demandas.

\subsection{ETAPA 2 - REDES NEURAIS}

Na segunda etapa foram formulados dois modelos de RNA, com finalidades distintas. A primeira, denominada "Rede A", teve como objetivo mapear os resultados da PD em termos da política de prioridades (PP) do AcquaNet. A segunda, "Rede B", foi formulada para reconhecer o padrão do atendimento às demandas, a partir dos resultados da PD.

Ambas as redes foram desenvolvidas em planilhas eletrônicas do Microsoft Excel 2013, e calculadas com o solver. O cálculo teve como objetivo minimizar a soma quadrática das diferenças os dados desejados e os dados calculados conforme a Equação 5.10:

$$
F_{o b j(R N)}=\min \left\{\sum_{i=1}^{k}\left(X_{i}-Y_{i}\right)^{2}\right\}
$$

Onde:

- Xi-dado desejado;

- Yi-dado calculado;

- $\mathrm{k}$ - número de dados no conjunto de treinamento da RNA.

Para avaliar a calibração dos modelos de rede neural foram analisados os coeficientes de correlação ( $r$ ), a raiz do erro quadrático médio (RMSE) e o coeficiente de eficiência de Nash-Sutcliffe (NSE), mostrados respectivamente nas equações 5.11, 5.12 e 5.13 . 


$$
\begin{aligned}
& r=\frac{\sum_{i=1}^{N}\left(X_{i}-\bar{X}\right) \cdot\left(Y_{i}-\bar{Y}\right)}{\sqrt{\left(\sum_{i=1}^{N}\left(X_{i}-\bar{X}\right)^{2}\right) \cdot\left(\sum_{i=1}^{N}\left(Y_{i}-\bar{Y}\right)^{2}\right)}} \\
& R M S E=\left[\frac{1}{N} \cdot \sum_{i=1}^{N}\left(X_{i}-Y_{i}\right)^{2}\right]^{1 / 2}
\end{aligned}
$$

$$
N S E=1-\frac{\sum_{i=1}^{N}\left(X_{i}-Y_{i}\right)^{2}}{\sum_{i=1}^{N}\left(X_{i}-\bar{X}\right)^{2}}
$$

Onde:

- $\bar{X}$ e $\bar{Y}$ - médias dos respectivos conjuntos de dados;

- $\quad N$ - número de elementos no conjunto.

A RMSE fornece uma indicação dos erros de predição do modelo, sendo desejáveis valores mais próximos de zero. Este coeficiente é uma medida bem aceita do erro absoluto das predições dos modelos (HARMEL e SMITH, 2007).

O coeficiente NSE foi proposto por Nash e Sutcliffe em 1970, sendo muito utilizado na avaliação estatística do desempenho em modelos hidrológicos (ALE et al., 2012). O NSE varia de $-\infty$ a 1 , sendo quanto mais perto de 1 , melhor a eficiência do modelo.

Para aplicação dos modelos de rede neural os dados de entrada foram normalizados conforme a equação a seguir:

$$
X i_{N}=\frac{\left(X i-X_{\min }\right)}{\left(X_{\max }-X_{\min }\right)}
$$

Onde:

- $X i_{N}$ - variável a ser normalizada;

- $X_{\max }, X_{\min }$ - valores máximos e mínimos das variáveis. 
Para a arquitetura das redes neurais, foram analisados arranjos diversos de dados de entrada, de número de camadas ocultas, de número de neurônios nas respectivas camadas, e de configuração das suas interconexões. Nas seções seguintes são apresentadas as tipologias selecionadas, que obtiveram melhor convergência, maior correlação e menor erro quadrático médio entre os conjuntos de dados de saída.

\subsubsection{Rede A}

O principal objetivo da Rede A é reconhecer o padrão da política de prioridades do AcquaNet a partir dos resultados das simulações preliminares. Conforme descrito no item 3.4, o modelo AcquaNet pode ser calibrado a partir de configurações de estados hidrológicos, e de políticas de prioridades para o reservatório e para as demandas.

Em particular, a definição das políticas de prioridades, ou pesos, no software AcquaNet possui grande influência sobre o desempenho da simulação. A Figura 5.5 exemplifica os resultados de um mesmo sistema, com cenários distintos de políticas de prioridades, em que nota-se os resultados para o comportamento dos volumes finais armazenados no reservatório. 


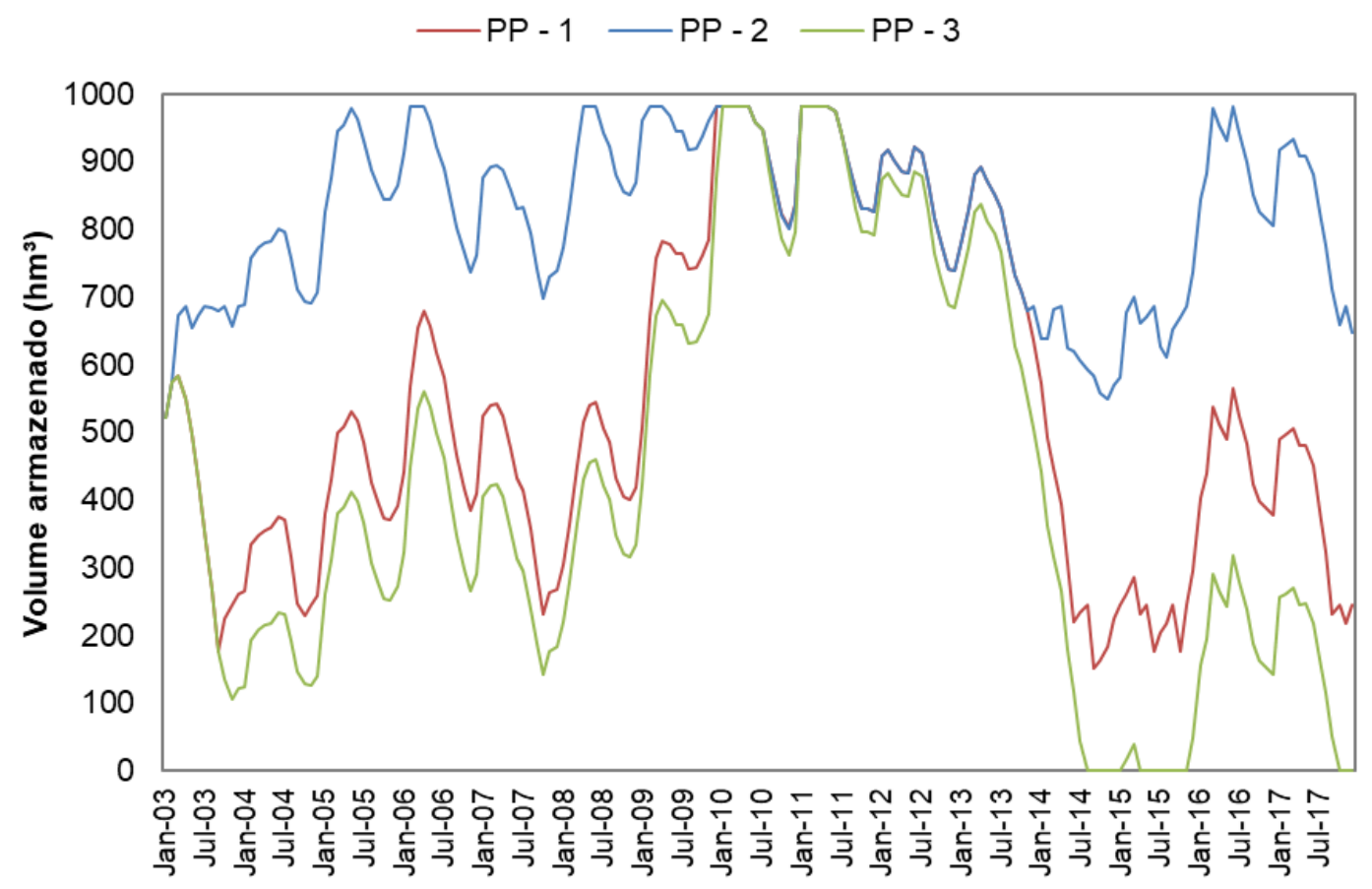

Figura 5.5 - Exemplos de resultados de volumes finais armazenados no RE, obtidos com simulações do AcquaNet, alterando-se apenas a política de prioridades (PP).

Desta forma, a Rede A foi utilizada como estratégia para transferir os resultados da PD em termos de uma política de prioridades. Seu treinamento foi a partir dos resultados de simulações preliminares do SC representado em uma rede de fluxo no AcquaNet.

A rede neural foi treinada com base em resultados de simulações preliminares com o AcquaNet, admitindo-se políticas de prioridades distintas. $O$ treinamento da Rede A e sua aplicação aos resultados da PD estão descritos a seguir.

5.2.1.1. Simulações preliminares e treinamento da Rede A

O modelo do SC admitido para a PD na Etapa 1 foi representado na rede de fluxo mostrada na Figura 5.6. 


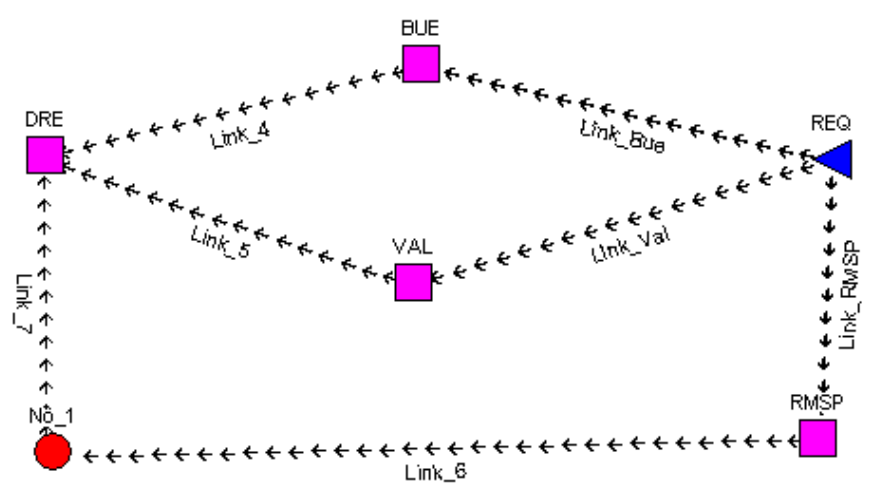

Figura 5.6 - Rede de fluxo do SC.

A fim de se obter regras operativas práticas, e análogas a atual política de operação do SC, optou-se pela pré-seleção de 4 configurações de faixas de operação a partir das quais procedeu-se a metodologia. As faixas de operação são mostradas na Tabela 5.2 em termos dos limites de volume útil. Vale ressaltar que a configuração 4 corresponde às faixas de operação vigente do SC, promulgadas pela resolução conjunta ANA/DAEE no 925/2017. Este modelo de operação, foi denominado "regra de operação por faixas". As faixas de operação são incorporadas ao AcquaNet por meio dos parâmetros de estados hidrológicos (EH).

Tabela 5.2 - Configurações de faixas de operação pré-definidas, em termos da porcentagem de volume útil.

\begin{tabular}{|c|c|c|c|c|c|}
\hline \multirow{2}{*}{$\begin{array}{c}\text { Faixas de operação } \\
\text { (Estados Hidrológicos) }\end{array}$} & \multicolumn{4}{c|}{$\begin{array}{c}\text { Configurações } \\
\text { disponibilidade de volume útil (\%) }\end{array}$} \\
\cline { 3 - 6 } & & 1 & 2 & 3 & 4 \\
\hline Faixa 5 & - & - & $\begin{array}{c}60 \%- \\
100 \%\end{array}$ & $\begin{array}{c}60 \%- \\
100 \%\end{array}$ \\
\hline Faixa 4 e 5 & Faixa 4 & $70 \%-100 \%$ & $\begin{array}{c}60 \%- \\
100 \%\end{array}$ & $50 \%-60 \%$ & $40 \%-60 \%$ \\
\hline Faixa 3 & Faixa 3 & $55 \%-70 \%$ & $30 \%-60 \%$ & $30 \%-50 \%$ & $30 \%-40 \%$ \\
\hline Faixa 2 \\
\hline Faixa 1 & Faixa 2 & $25 \%-55 \%$ & $15 \%-30 \%$ & $15 \%-30 \%$ & $20 \%-30 \%$ \\
\hline
\end{tabular}

Devido às limitações do solver do Microsoft excel quanto ao número de variáveis em sua versão padrão, foram selecionados 3 cenários representativos de políticas de prioridades distintas para as regras operativas. Estes cenários foram selecionados aleatoriamente entre combinações de políticas de prioridades distintas, e representam as possíveis configurações desejáveis de operação do modelo. A 
Figura 5.7 apresenta de maneira esquemática a estratégia descrita, para cada configuração de regra operativa. Os resultados das simulações preliminares com o AcquaNet formam o conjunto de dados para o treinamento da Rede A.
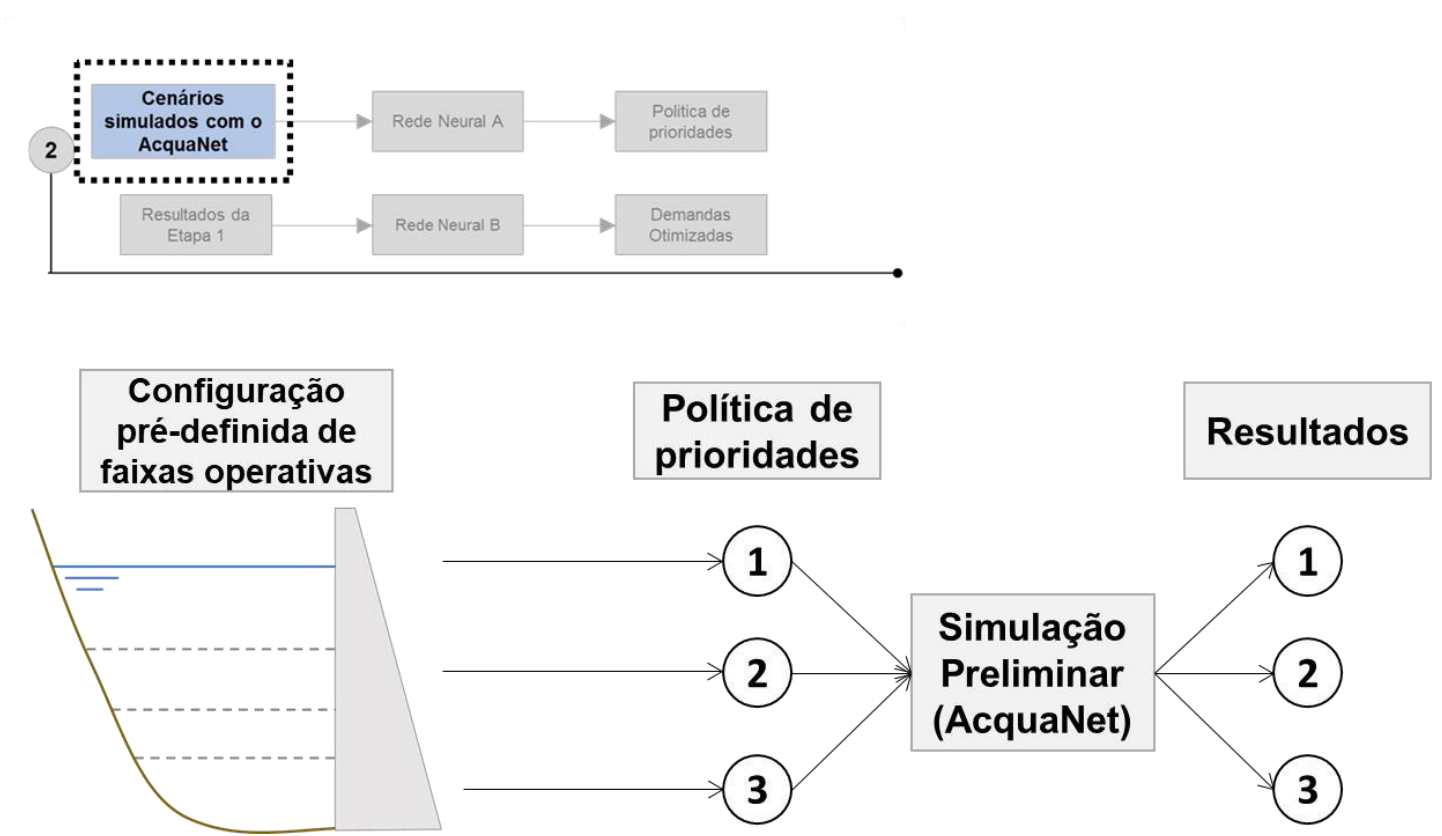

Figura 5.7 - Fluxograma de simulações preliminares para obtenção conjunto de dados de treinamento da Rede A, de acordo com configurações de regra operativa pré-definidas.

Esta metodologia admite as seguintes hipóteses:

- As faixas de operação pré-definidas aproximam-se das características desejáveis para obtenção de regras operativas.

- O comportamento desejável do sistema, em termos de política de prioridades, aproxima-se de uma configuração em que no estado com maior volume útil disponível, prioriza-se o atendimento às demandas.

A Tabela 5.3 mostra as características das simulações preliminares do modelo AcquaNet, cujas afluências naturais foram idênticas às utilizadas na Etapa 1 (Figura 5.3 e Figura 5.4). 
Tabela 5.3 - Características das simulações preliminares do modelo AcquaNet para as configurações de faixa de operação apresentadas.

\begin{aligned} & \hline $\begin{array}{r}\text { Simulações preliminares - Rede de fluxo AcquaNet } \\ \text { Período de simulação }\end{array} 2003$ - 2017 (15 anos) \\ & \hline Discretização $\begin{array}{l}\text { mensal } \\ 180 \text { meses }\end{array} \\ &$\hline Tipos de simulação $\begin{array}{l}\text { Simulação Contínua } \\ \text { Estados Hidrológicos }\end{array} \\ &$ № de Reservatórios 1 \\ & \hline № de Demandas 3 \\ & \hline Política de prioridades simuladas 3 \\ & \hline № total de dados resultantes 540 meses \\ & \hline\end{aligned}

A Rede A foi configurada com uma camada de entrada, duas camadas ocultas, a primeira composta por três neurônios e a segunda por quatro, além de uma camada de saída com quatro resultados. A saída da Rede A foi comparada aos valores das prioridades do AcquaNet, para o reservatório e para os pontos de controle.

Os dados de entrada da Rede A foram a vazão afluente ao ponto de controle, vazão afluente total ao sistema, volume inicial armazenado, volume final armazenado, demanda, vazão fornecida, déficit e vazão total obtida no ponto de controle. A Figura 5.8 mostra sua tipologia, e a Tabela 5.4 resume seus parâmetros.

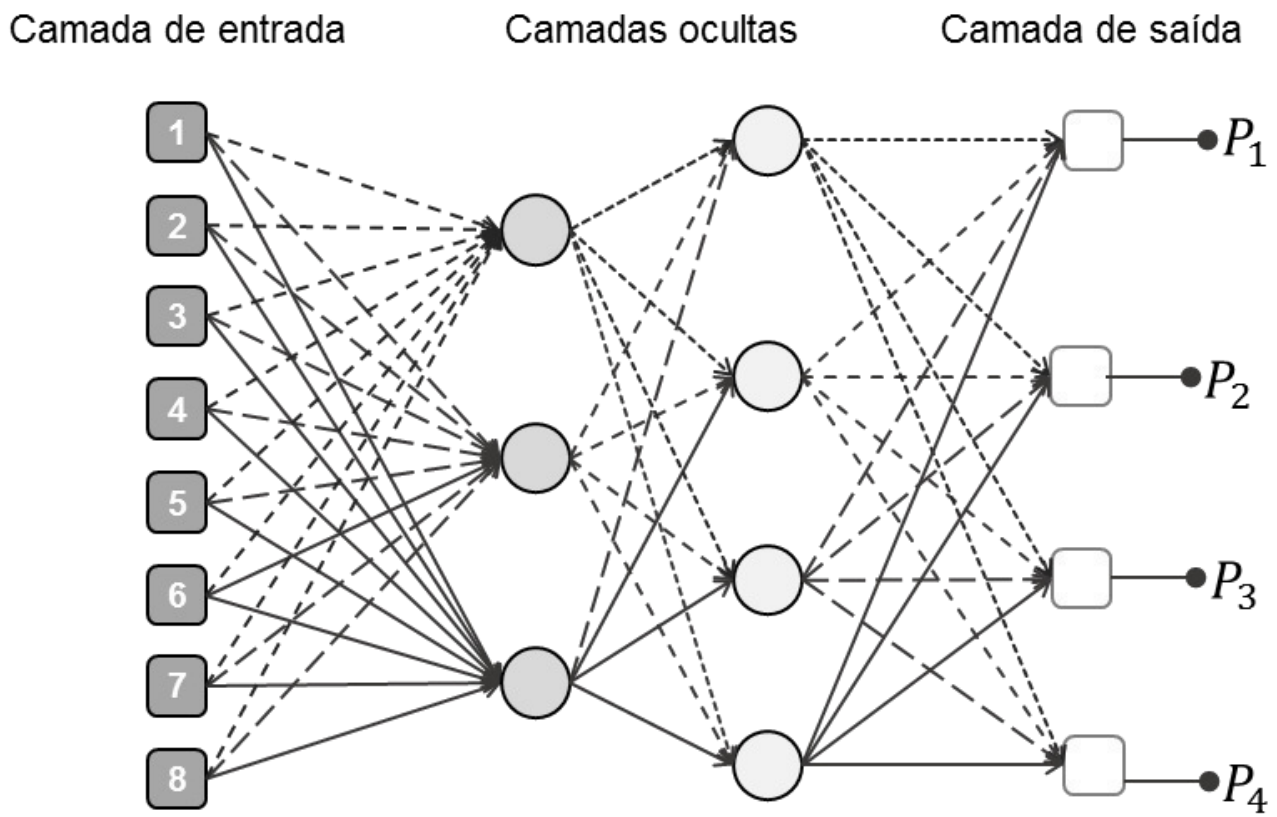

Figura 5.8 - Tipologia da Rede A. 
Tabela 5.4 - Parâmetros de entrada e saída da Rede A.

\begin{tabular}{|c|c|c|}
\hline \multicolumn{3}{|c|}{ Dados para treinamento da Rede $\mathrm{A}$} \\
\hline Origem & \multicolumn{2}{|c|}{$\begin{array}{l}\text { Resultados de } 3 \text { simulações com o AcquaNet, com políticas de prioridades } \\
\text { distintas }\end{array}$} \\
\hline total & \multicolumn{2}{|l|}{540 entradas } \\
\hline \multicolumn{2}{|r|}{ Neurônios de Entrada } & Neurônios de saída \\
\hline 1 & $\begin{array}{l}\text { Vazão natural ao ponto de } \\
\text { controle }\end{array}$ & $\begin{array}{l}\text { P1 - Prioridade relativa do volume meta no } \\
\text { RE }\end{array}$ \\
\hline 2 & $\begin{array}{l}\text { Soma das vazões naturais ao } \\
\text { sistema }\end{array}$ & P2 - Prioridade relativa da demanda RMSP \\
\hline 3 & Volume inicial do RE & $\begin{array}{l}\text { P3 - Prioridade relativa da demanda } \\
\text { Buenópolis }\end{array}$ \\
\hline 4 & Volume final do RE & P4 - Prioridade relativa da demanda Valinhos \\
\hline 5 & $\begin{array}{l}\text { Demanda requerida ao ponto de } \\
\text { controle }\end{array}$ & \\
\hline 6 & $\begin{array}{l}\text { Vazão fornecida para o ponto de } \\
\text { controle }\end{array}$ & \\
\hline 7 & Déficit de atendimento & \\
\hline 8 & $\begin{array}{l}\text { Vazão total observada no ponto } \\
\text { de controle }\end{array}$ & \\
\hline
\end{tabular}

\subsubsection{Política de Prioridades}

Após o treinamento das redes, para as configurações pré-definidas, foram avaliadas as distribuições da política de prioridades para o AcquaNet, com base nos resultados da PD. Esta aplicação tem como referência a capacidade da rede neural de transferir o conhecimento adquirido a um novo conjunto de dados. Sendo assim, é possível representar a otimização por PD em termos de políticas de prioridades do AcquaNet.

A composição média da PP, para os volumes dos referidos estados hidrológicos, e para as demandas, foi obtida:

$$
P_{i, j}=\frac{\left(\sum_{k=1}^{l i, j} X_{k, i j}\right)}{l_{i, j}}
$$

Onde: 
- $\mathrm{P}_{\mathrm{ij}}$ - Prioridade média do elemento i, no estado hidrológico j. O elemento i referese ao reservatório, à demanda da RMSP, à demanda de Buenópolis, ou à de Valinhos.

- $\mathrm{X}_{\mathrm{k}, \mathrm{j}}$ - k-ésimo resultado da prioridade do elemento i, no estado hidrológico j;

- lij-número total de elementos i no estado hidrológico j.

\subsubsection{Rede B}

O objetivo da rede neural $B$ é identificar o padrão de atendimento às demandas do modelo da PD apresentado na Etapa 1 (item 5.1). Com este procedimento foi possível inferir valores de demandas requeridas para todas as configurações de regras operativas, em cada faixa de operação.

Diferentemente da Rede A os dados para o treinamento da Rede B foram os resultados da PD. O treinamento da Rede B e a obtenção das regras operativas estão descritos a seguir. 
5.2.2.1. Configuração e treinamento da Rede B
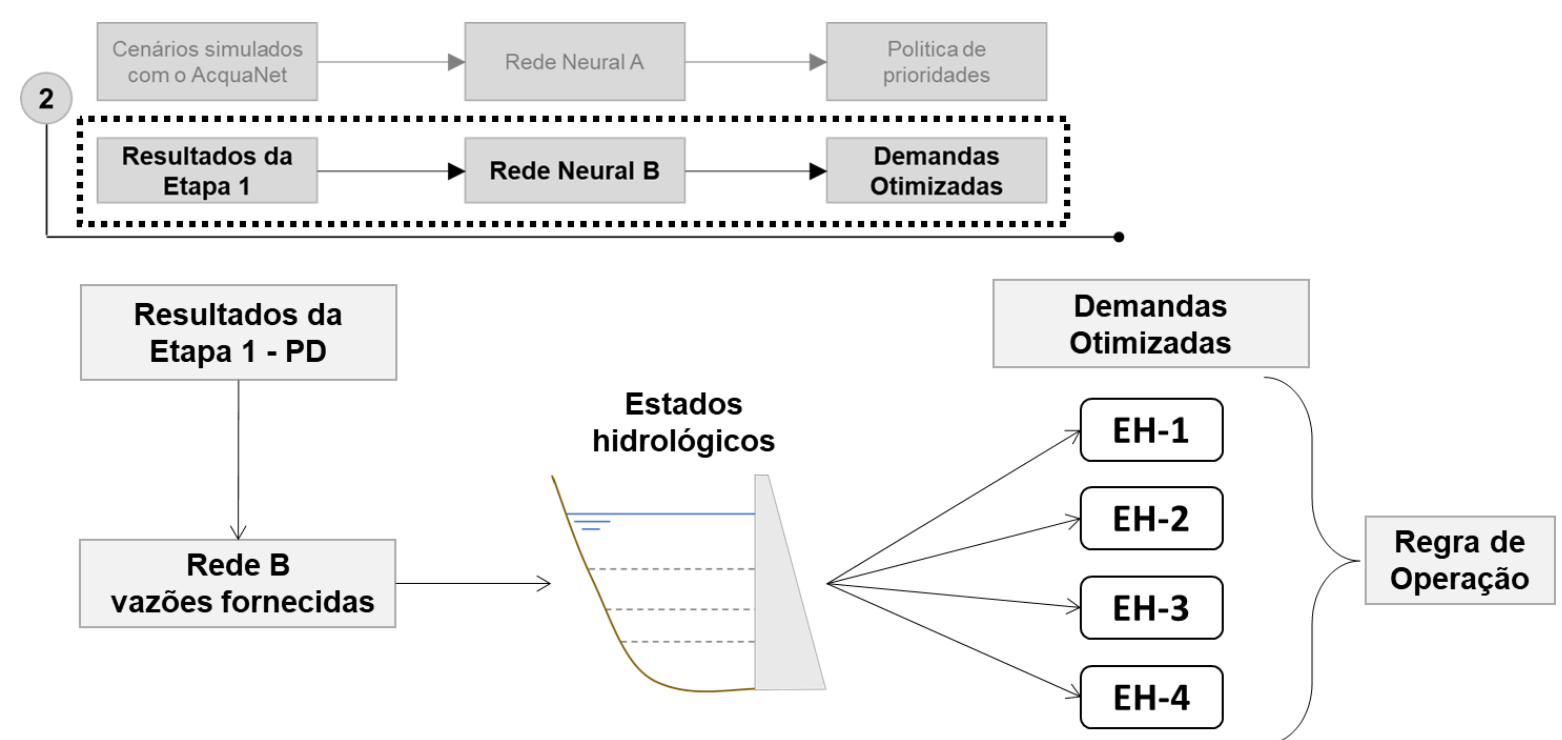

Figura 5.9 - Fluxograma da obtenção das demandas requeridas por faixa de operação, com auxílio da Rede B.

A Rede $B$ foi configurada com duas camadas ocultas, com 3 neurônios cada. A saída da Rede B foi comparada aos valores de vazão fornecida da PD para os pontos de controle.

A análise não tem caráter de previsão de vazões, desse modo os dados de entrada da Rede B foram os resultados da PD para o período atual de vazão afluente ao ponto de controle, vazão afluente total ao sistema, volume inicial armazenado, volume final armazenado e vazão fornecida.

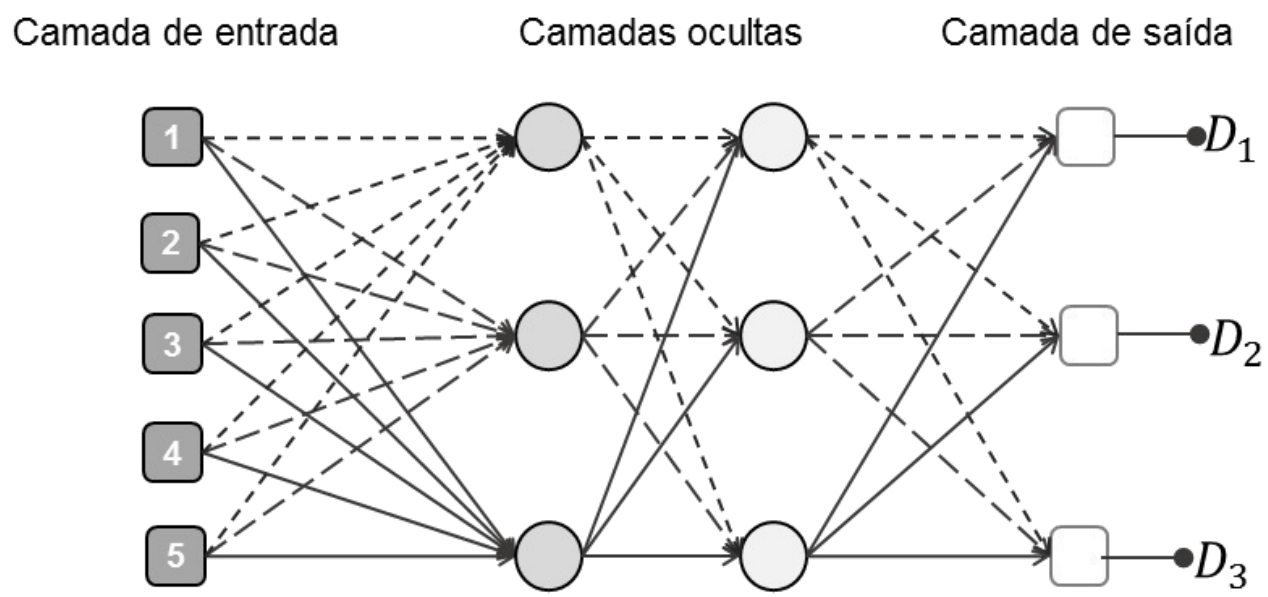

Figura 5.10 - Tipologia da Rede B. 
Tabela 5.5 - Parâmetros de entrada e saída da Rede B.

\begin{tabular}{|c|c|c|}
\hline \multicolumn{3}{|c|}{ Dados para treinamento da Rede B } \\
\hline Origem & \multicolumn{2}{|c|}{ Resultados da otimização por PD determinística (Etapa 1) } \\
\hline total & \multicolumn{2}{|c|}{180 entradas } \\
\hline \multicolumn{2}{|r|}{ Neurônios de Entrada } & Neurônios de saída \\
\hline 1 & $\begin{array}{l}\text { Vazão natural ao ponto de } \\
\text { controle }\end{array}$ & D1 - Vazão fornecida para RMSP \\
\hline 2 & $\begin{array}{l}\text { Soma das vazões naturais ao } \\
\text { sistema }\end{array}$ & D2 - Vazão fornecida para Buenópolis \\
\hline 3 & Volume inicial do RE & D3- Vazão fornecida para Valinhos \\
\hline 4 & Volume final do RE & \\
\hline 5 & $\begin{array}{l}\text { Vazão fornecida para o ponto de } \\
\text { controle }\end{array}$ & \\
\hline
\end{tabular}

\subsubsection{Demandas otimizadas}

Após o treinamento da Rede $B$, foram analisadas as vazões fornecidas para os pontos de controle a partir do estado de armazenamento do RE. Desta forma foi possível obter valores de demandas requeridas e garantias para as faixas de operação das regras pré-definidas.

Esta aplicação resultou em 4 regras operativas com valores de demandas requeridos por faixa de operação.

\subsection{ETAPA 3 - SIMULAÇÃO}

Nesta etapa foram analisados os desempenhos das regras operativas obtidas com a metodologia proposta, através de simulação da rede de fluxo do SC com auxílio do AcquaNet, porém utilizando-se as vazões afluentes da série histórica (1930 2017).

A composição da regra operativa foi a partir da política de prioridades dos elementos do sistema, obtidos com auxílio da Rede $A$, e as demandas requeridas obtidas com a Rede B. As regras foram incorporadas ao AcquaNet com as faixas de operação representadas por estados hidrológicos.

As vazões naturais de entrada do modelo são mostradas na Figura 5.11 e na Figura 5.12. 


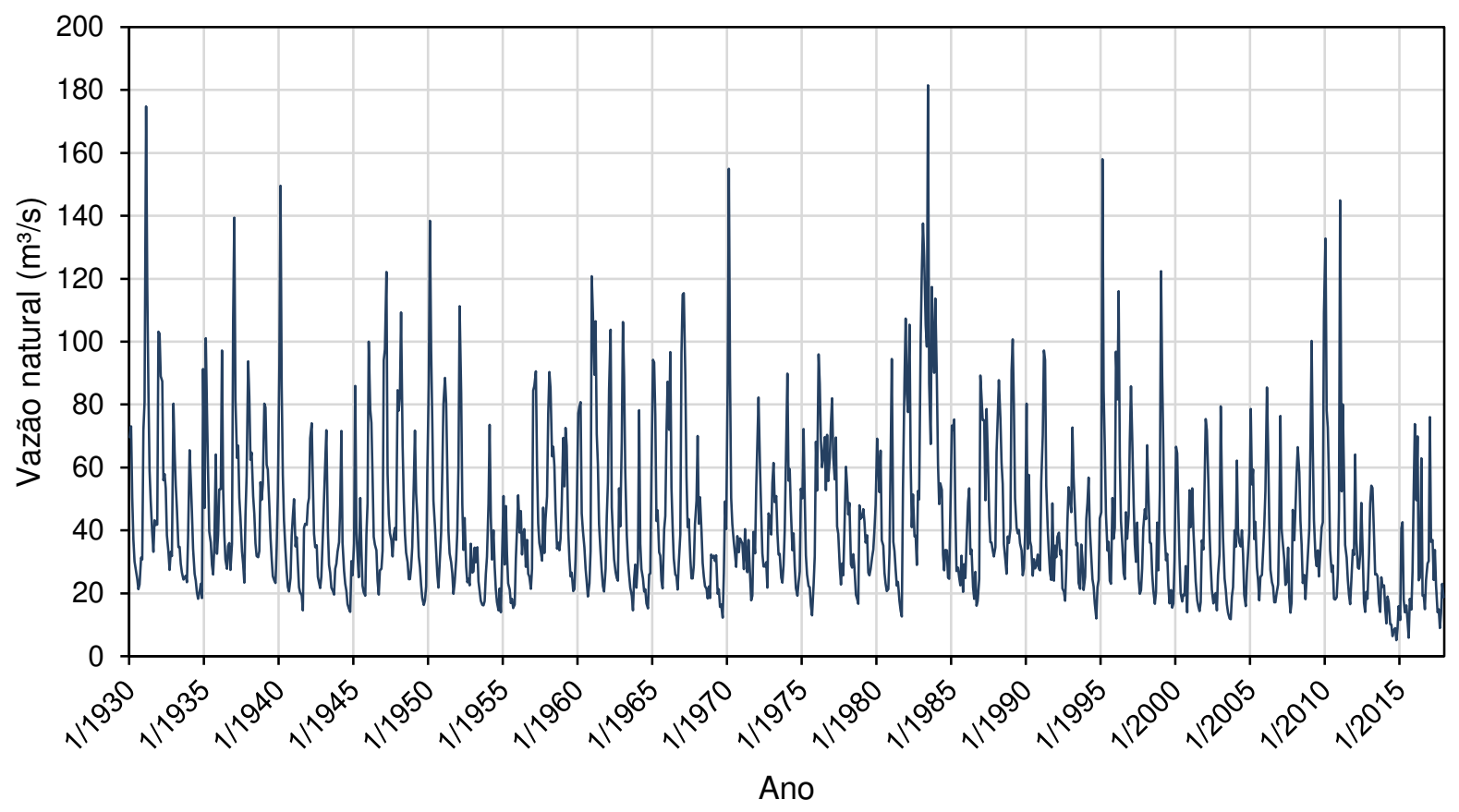

Figura 5.11 - Vazões médias mensais afluentes ao reservatório equivalente do SC de janeiro/1930 a dezembro/2017.

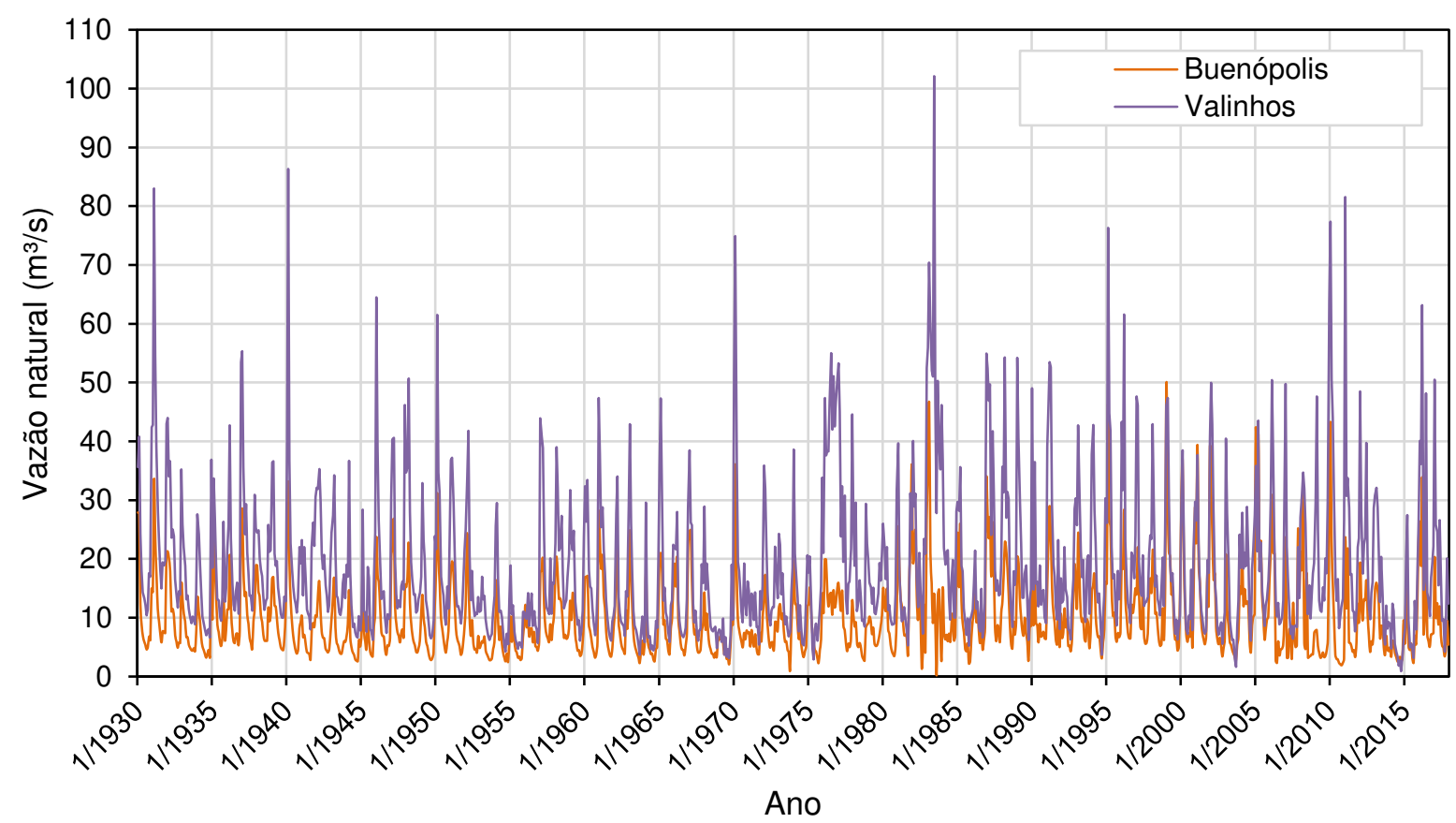

Figura 5.12 - Vazões médias mensais afluentes a Buenópolis e Valinhos de janeiro/1930 a dezembro/2017. 
As 4 regras propostas foram analisadas em termos dos volumes finais armazenados no RE, e do fornecimento às demandas. A Tabela 5.6 mostra o resumo das características das simulações.

Tabela 5.6 - Características das simulações do modelo AcquaNet na Etapa 3.

\begin{tabular}{r:l}
\hline Simulações das regras de operação - AcquaNet \\
\hdashline Período de simulação & 1930 - 2017 (88 anos) \\
\hdashline Discretização & mensal \\
& 1.056 meses \\
\hdashline Tipos de simulação & Simulação Contínua \\
& Estados Hidrológicos \\
\hdashline № de Reservatórios & 1 \\
\hdashline № de Demandas & 3 \\
\hdashline Política de prioridades & Obtidas na Etapa 2 \\
\hdashline Demandas requeridas & Obtidas na Etapa 2 \\
\hdashline № total de simulações & 4 \\
\hline
\end{tabular}




\section{RESULTADOS E DISCUSSÃO}

Os resultados obtidos pela metodologia descrita são mostrados nas seções seguintes, separados por etapas. O item 6.3 apresenta os resultados das simulações para as regras de operação na série histórica (1930 - 2017) do Sistema Cantareira.

\subsection{ETAPA 1 - PROGRAMAÇÃO DINÂMICA}

O modelo de otimização por PD foi capaz de representar convenientemente o problema de otimização e embora apresentasse 180 estágios, foi calculado rapidamente pelo CSUDP devido ao uso combinado das técnicas de DPSA e IDP, conforme mencionado por Labadie (2010). O modelo, que convergiu ao resultado otimizado após 2603 iterações.

A Figura 6.1 apresenta os volumes armazenados no RE do Sistema Cantareira ao final de cada mês, e as permanências destes valores.

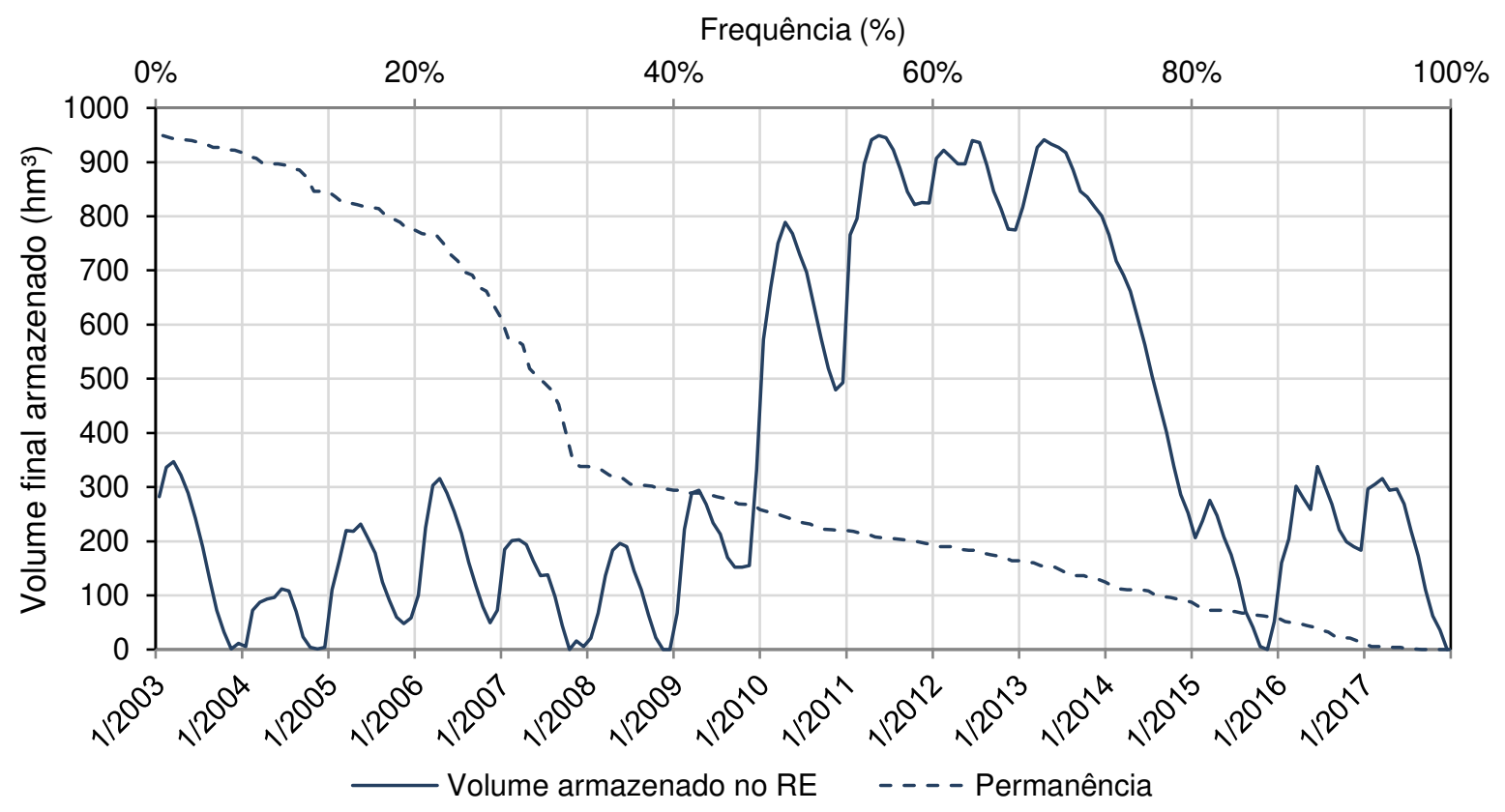

Figura 6.1 - Volumes finais de armazenamento do RE e respectiva permanência, obtidos pela PD durante os anos de 2003 a 2017. 
$\mathrm{O}$ equacionamento matemático do modelo de PD priorizou o atendimento às demandas em detrimento da conservação do volume útil do reservatório, o que pode ser observado na Figura 6.1 pelos três períodos em que ocorre o esgotamento do volume útil: em outubro/2007, entre novembro e dezembro/2008 e em novembro de 2015.

A Figura 6.2 mostra as vazões fornecidas para RMSP, e para os pontos de controle em Buenópolis e Valinhos ao longo do período e as respectivas permanências.

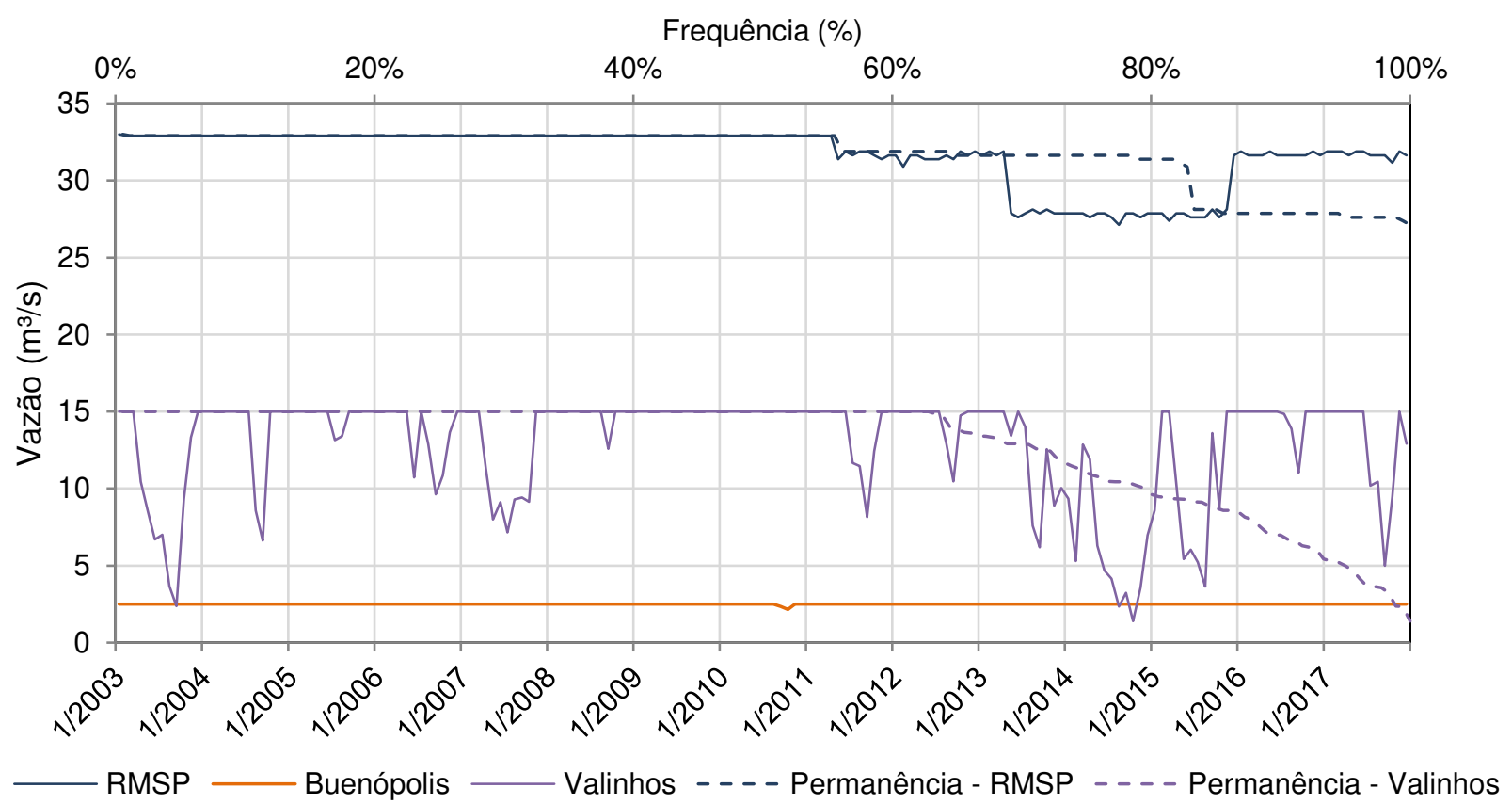

Figura 6.2 - Vazões fornecidas pelo RE às demandas RMSP, Buenópolis e Valinhos, e respectivas permanência, obtidas pela PD durante os anos de 2003 a 2017.

Com relação ao fornecimento para a RMSP o modelo de otimização apresentou alta eficiência no atendimento da RMSP, com vazões mínimas de 27,10 m³/s durante o período.

Embora tenha ocorrido déficits no atendimento à demanda de Buenópolis, a permanência de atendimento a este ponto de controle foi de $99 \%$ para o valor integral da demanda requerida $\left(2,5 \mathrm{~m}^{3} / \mathrm{s}\right)$. No ponto de controle de Valinhos, o reservatório foi capaz de fornecer o valor da demanda integral $\left(15 \mathrm{~m}^{3} / \mathrm{s}\right)$ durante $63 \%$ do período. Esta diferença deve-se às magnitudes dos valores requeridos pelos pontos de controle, 
pois Valinhos requer uma quantidade maior de água do que Buenópolis, além disso o modelo prioriza o atendimento à RMSP do que aos pontos de controle.

Os resultados mostram o impacto da seca enfrentada pelo SC no biênio de 2013 e 2014, pois apesar de atender às demandas de maneira satisfatória, o RE ficou sujeito ao esgotamento de sua capacidade.

\subsection{ETAPA 2 - REDES NEURAIS}

Nesta etapa apresenta-se os resultados conforme a metodologia descrita no item 5.2 para os modelos Rede A e Rede B.

\subsubsection{Rede A}

De posse das configurações preliminares de regras operativas apresentadas anteriormente (Tabela 5.2), e do modelo de rede de fluxo do Sistema Cantareira no AcquaNet, selecionou-se combinações distintas de políticas de prioridade (PP) para os elementos do sistema. As combinações das PP para as regras estão mostradas a seguir da Erro! Fonte de referência não encontrada. à Tabela 6.4.

Tabela 6.1 - Regra 1 - Políticas de prioridades utilizadas para as pré-simulações do

AcquaNet.

\begin{tabular}{|c|c|c|c|c|c|}
\hline & \multirow[b]{2}{*}{ Regra 1} & \multicolumn{4}{|c|}{ Faixas de operação e Porcentagens do volume útil } \\
\hline & & $\begin{array}{l}\text { Faixa } 1 \\
0-25 \%\end{array}$ & $\begin{array}{c}\text { Faixa } 2 \\
25 \%-55 \%\end{array}$ & $\begin{array}{c}\text { Faixa } 3 \\
55 \%-70 \%\end{array}$ & $\begin{array}{c}\text { Faixa } 4 \\
70 \%-100 \%\end{array}$ \\
\hline \multirow{4}{*}{ PP 1} & $\mathrm{RE}$ & 5 & 15 & 5 & 20 \\
\hline & Buenópolis & 30 & 30 & 5 & 15 \\
\hline & RMSP & 15 & 5 & 30 & 10 \\
\hline & Valinhos & 5 & 20 & 25 & 20 \\
\hline \multirow{4}{*}{ PP 2} & $\mathrm{RE}$ & 15 & 15 & 20 & 30 \\
\hline & Buenópolis & 15 & 20 & 20 & 20 \\
\hline & RMSP & 5 & 5 & 5 & 10 \\
\hline & Valinhos & 10 & 15 & 15 & 15 \\
\hline
\end{tabular}




\begin{tabular}{cc|cccc}
\hline & RE & 5 & 15 & 15 & 30 \\
\cline { 2 - 6 } PP 3 & Buenópolis & 25 & 20 & 15 & 15 \\
\cline { 2 - 6 } & RMSP & 5 & 5 & 5 & 5 \\
\cline { 2 - 7 } & Valinhos & 15 & 10 & 10 & 10 \\
\hline
\end{tabular}

Tabela 6.2 - Regra 2 - Políticas de prioridades utilizadas para as pré-simulações do AcquaNet.

\begin{tabular}{cc|cccc} 
& & \multicolumn{4}{|c}{ Faixas de operação e Porcentagens do volume útil } \\
\cline { 3 - 7 } & Regra 2 & Faixa 1 & Faixa 2 & Faixa 3 & Faixa 4 \\
& & $0-15 \%$ & $15 \%-30 \%$ & $30 \%-60 \%$ & $60 \%-100 \%$ \\
\hline \multirow{3}{*}{ PP 1 } & RE & 5 & 10 & 20 & 30 \\
\cline { 2 - 6 } & Buenópolis & 25 & 25 & 25 & 25 \\
\cline { 2 - 6 } & RMSP & 10 & 10 & 10 & 10 \\
\cline { 2 - 6 } & Valinhos & 15 & 15 & 20 & 20 \\
\hline \multirow{3}{*}{ PP 2 } & RE & 15 & 15 & 30 & 30 \\
\cline { 2 - 6 } & Buenópolis & 10 & 25 & 20 & 10 \\
\cline { 2 - 6 } & RMSP & 5 & 5 & 5 & 5 \\
\cline { 2 - 6 } & Valinhos & 10 & 20 & 10 & 10 \\
\hline \multirow{3}{*}{ PP 3 } & RE & 5 & 15 & 5 & 20 \\
\cline { 2 - 6 } & Buenópolis & 30 & 30 & 5 & 15 \\
\cline { 2 - 6 } & RMSP & 15 & 5 & 30 & 10 \\
\cline { 2 - 6 } & Valinhos & 15 & 10 & 10 & 10 \\
\hline
\end{tabular}

Tabela 6.3 - Regra 3 - Políticas de prioridades utilizadas para as pré-simulações do AcquaNet.

\begin{tabular}{|c|c|c|c|c|c|c|}
\hline & \multirow{3}{*}{ Regra 3} & \multicolumn{4}{|c|}{ Faixas de operação e Porcentagens do volume útil } & \multirow{3}{*}{$\begin{array}{c}\text { Faixa } 5 \\
60 \%-100 \%\end{array}$} \\
\hline & & Faixa 1 & Faixa 2 & Faixa 3 & Faixa 4 & \\
\hline & & $0-15 \%$ & $15 \%-30 \%$ & $30 \%-50 \%$ & $50 \%-60 \%$ & \\
\hline \multirow{4}{*}{ PP 1} & $\mathrm{RE}$ & 5 & 20 & 25 & 30 & 30 \\
\hline & Buenópolis & 10 & 25 & 30 & 15 & 10 \\
\hline & RMSP & 15 & 15 & 10 & 10 & 10 \\
\hline & Valinhos & 25 & 20 & 20 & 25 & 15 \\
\hline \multirow{4}{*}{ PP 2} & $\mathrm{RE}$ & 30 & 30 & 30 & 30 & 30 \\
\hline & Buenópolis & 20 & 20 & 20 & 10 & 20 \\
\hline & RMSP & 5 & 10 & 5 & 20 & 10 \\
\hline & Valinhos & 5 & 15 & 10 & 10 & 15 \\
\hline \multirow{4}{*}{ PP 3} & $\mathrm{RE}$ & 5 & 5 & 20 & 25 & 30 \\
\hline & Buenópolis & 25 & 10 & 15 & 20 & 30 \\
\hline & RMSP & 5 & 5 & 10 & 10 & 5 \\
\hline & Valinhos & 10 & 5 & 15 & 10 & 20 \\
\hline
\end{tabular}


Tabela 6.4 - Regra 4 - Políticas de prioridades utilizadas para as pré-simulações do AcquaNet.

\begin{tabular}{|c|c|c|c|c|c|c|}
\hline & \multirow{3}{*}{ Regra 4} & \multicolumn{4}{|c|}{ Faixas de operação e Porcentagens do volume útil } & \multirow{3}{*}{$\begin{array}{c}\text { Faixa } 5 \\
60 \%-100 \%\end{array}$} \\
\hline & & Faixa 1 & Faixa 2 & Faixa 3 & Faixa 4 & \\
\hline & & $0-20 \%$ & $20 \%-30 \%$ & $30 \%-40 \%$ & $40 \%-60 \%$ & \\
\hline \multirow{4}{*}{ PP 1} & $\mathrm{RE}$ & 10 & 15 & 20 & 20 & 30 \\
\hline & Buenópolis & 25 & 25 & 25 & 25 & 25 \\
\hline & RMSP & 5 & 10 & 10 & 20 & 15 \\
\hline & Valinhos & 10 & 20 & 20 & 25 & 25 \\
\hline \multirow{4}{*}{ PP 2} & RE & 15 & 20 & 20 & 30 & 30 \\
\hline & Buenópolis & 25 & 20 & 20 & 30 & 15 \\
\hline & RMSP & 10 & 15 & 10 & 15 & 5 \\
\hline & Valinhos & 15 & 20 & 10 & 20 & 5 \\
\hline \multirow{4}{*}{ PP 3} & $\mathrm{RE}$ & 5 & 20 & 30 & 15 & 30 \\
\hline & Buenópolis & 25 & 20 & 20 & 25 & 25 \\
\hline & RMSP & 10 & 10 & 10 & 10 & 15 \\
\hline & Valinhos & 10 & 20 & 5 & 10 & 10 \\
\hline
\end{tabular}

Os resultados das simulações preliminares destes cenários foram compilados, de modo que a Rede A pudesse ser treinada para obter as políticas de prioridades iniciais. Foram realizados 4 treinamentos da Rede A, um para cada regra preliminar.

A Rede A apresentou bons resultados, ao mapear a política de prioridades do AcquaNet, possibilitando a sua aplicação a um novo conjunto de dados. A convergência para os resultados utilizando-se o solver do Microsoft Excel foi lenta, devido ao número de dados na camada de entrada (8) e ao número de dados totais para o treinamento da rede (540).

Para inicialização dos cálculos os pesos das ligações foram definidos com a função "aleatório", e o solver foi acionado a fim de minimizar a soma quadrática das diferenças entre as prioridades desejadas e as calculadas, em todos os elementos da rede (reservatório e demandas).

A Figura 6.3 mostra um exemplo das etapas de cálculo e resultados da Rede $A$, para uma entrada de informações da regra preliminar 1. $P_{1}, P_{2}, P_{3}$ e $P_{4}$ representam as políticas de prioridade quanto ao reservatório, à RMSP, à Buenópolis, e à Valinhos respectivamente. Os valores desejados são a PP utilizada na pré-simulação deste mesmo cenário com o AcquaNet. 


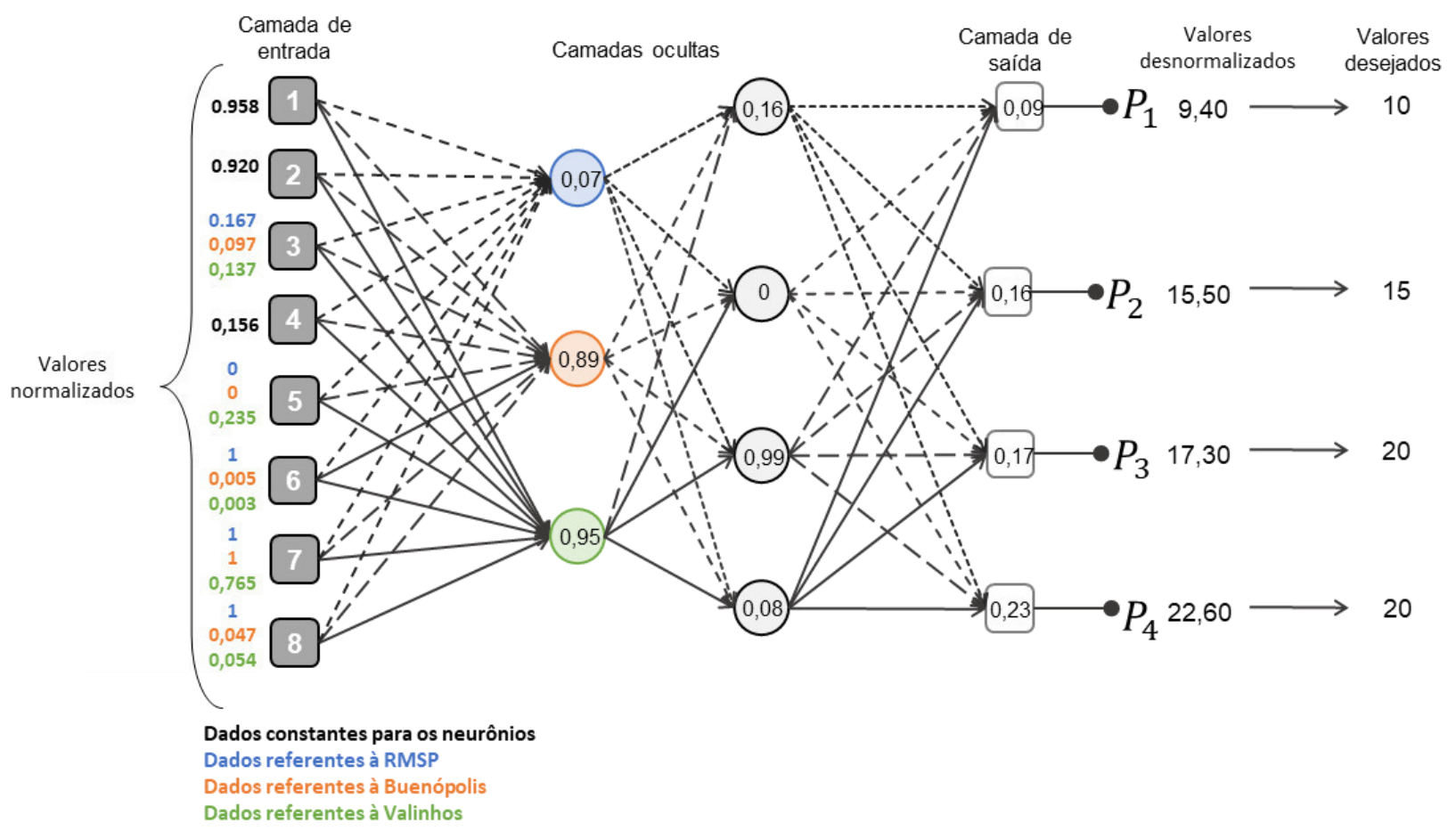

Figura 6.3 - Exemplo de estapas de cálculo da Rede A para um conjunto de dados de entrada.

A Tabela 6.5 mostra os coeficientes obtidos para a soma quadrática das diferenças $(\mathrm{Sq})$, de correlação $(r)$, raiz do erro quadrático médio (RMSE) e de coeficiente de eficiência de Nash-Sutcliffe, para os conjuntos de dados de cada regra.

Tabela 6.5 - Soma quadrática das diferenças (Sq), correlação (r), raiz do erro quadrático médio (RMSE) e coeficiente de eficiência de Nash-Sutcliffe, entre as prioridades utilizadas nas simulações preliminares (AcquaNet) e a Rede A.

\begin{tabular}{ccccc}
\hline Regra & $\mathrm{Sq}$ & $\mathrm{r}$ & $\mathrm{RMSE}$ & $\mathrm{NSE}$ \\
\hline Regra 1 & 1.44 & 0.92 & 0.03 & 0.85 \\
Regra 2 & 2.74 & 0.87 & 0.04 & 0.78 \\
Regra 3 & 4.23 & 0.85 & 0.04 & 0.75 \\
Regra 4 & 3.99 & 0.83 & 0.04 & 0.77 \\
\hline
\end{tabular}

A Tabela 6.6 mostra os resultados da composição média das políticas de prioridade obtidas com a Rede A para as regras de operação. 
Tabela 6.6 - Prioridades das demandas e volumes para as regras de operação.

\begin{tabular}{|c|c|c|c|c|}
\hline \multirow{3}{*}{ Regra 1} & \multicolumn{4}{|c|}{ Faixas de operação e Porcentagens do volume útil } \\
\hline & Faixa 1 & Faixa 2 & Faixa 3 & Faixa 4 \\
\hline & $0-25 \%$ & $25 \%-55 \%$ & $55 \%-70 \%$ & $70 \%-100 \%$ \\
\hline $\mathrm{RE}$ & 15 & 14 & 24 & 20 \\
\hline RMSP & 5 & 5 & 8 & 11 \\
\hline Buenópolis & 17 & 19 & 19 & 14 \\
\hline Valinhos & 11 & 12 & 14 & 18 \\
\hline \multirow{3}{*}{ Regra 2} & \multicolumn{4}{|c|}{ Faixas de operação e Porcentagens do volume útil } \\
\hline & Faixa 1 & Faixa 2 & Faixa 3 & Faixa 4 \\
\hline & $0-15 \%$ & $15 \%-30 \%$ & $30 \%-60 \%$ & $60 \%-100 \%$ \\
\hline $\mathrm{RE}$ & 15 & 17 & 22 & 23 \\
\hline RMSP & 5 & 7 & 7 & 10 \\
\hline Buenópolis & 19 & 20 & 23 & 16 \\
\hline Valinhos & 13 & 17 & 17 & 18 \\
\hline
\end{tabular}

\begin{tabular}{rccccc}
\hline & \multicolumn{5}{c}{ Faixas de operação e Porcentagens do volume útil } \\
\cline { 2 - 6 } Regra 3 & Faixa 1 & Faixa 2 & Faixa 3 & Faixa 4 & Faixa 5 \\
& $0-15 \%$ & $15 \%-30 \%$ & $30 \%-50 \%$ & $50 \%-60 \%$ & $60 \%-100 \%$ \\
\hline RE & 29 & 24 & 22 & 27 & 30 \\
\hline RMSP & 7 & 12 & 10 & 11 & 8 \\
\hline Buenópolis & 20 & 22 & 21 & 18 & 21 \\
\hline Valinhos & 8 & 17 & 17 & 15 & 17 \\
\hline
\end{tabular}

\begin{tabular}{rccccc}
\hline \multirow{2}{*}{ Regra 4 } & \multicolumn{5}{c}{ Faixas de operação e Porcentagens do volume útil } \\
\cline { 2 - 6 } & Faixa 1 & Faixa 2 & Faixa 3 & Faixa 4 & Faixa 5 \\
& $0-20 \%$ & $20 \%-30 \%$ & $30 \%-40 \%$ & $40 \%-60 \%$ & $60-100 \%$ \\
\hline RE & 16 & 20 & 25 & 23 & 27 \\
\hline RMSP & 11 & 12 & 12 & 12 & 16 \\
\hline Buenópolis & 23 & 21 & 19 & 25 & 23 \\
\hline Valinhos & 16 & 20 & 16 & 14 & 18 \\
\hline
\end{tabular}

\subsubsection{Rede B}

A rede $B$ foi calibrada a partir dos resultados da PD (etapa 1). Os dados de entrada da foram os resultados da PD para o período atual de vazão afluente ao respectivo ponto de controle, vazão afluente total ao sistema, volumes inicial e final 
armazenados no reservatório e vazão fornecida, configuração similar à apresentada pelos modelos de rede neural formulados por Raman e Chandramouli (1996), e Cancelliere et al. (2002).

A saída da Rede B foi comparada aos valores de vazão fornecida da PD para os pontos de controle.

A Rede $B$ apresentou convergência mais rápida do que a Rede $A$, e obteve bons resultados. Para inicialização dos cálculos os pesos das ligações foram definidos com a função "aleatório", e o solver foi acionado a fim de minimizar a soma quadrática das diferenças entre as vazões da PD e as vazões calculadas, para as demandas da RMSP, de Buenópolis e de Valinhos.

A Figura 6.4 mostra um exemplo das etapas de cálculo e resultados da Rede b, para uma entrada de dados da PD. $D_{1}, D_{2}, D_{3}$ representam os valores de vazão fornecida $\left(\mathrm{m}^{3} / \mathrm{s}\right)$ obtidos com a rede neural.para RMSP, Buenópolis, e Valinhos respectivamente. Os valores desejados são os dados de fornecimentos da PD.

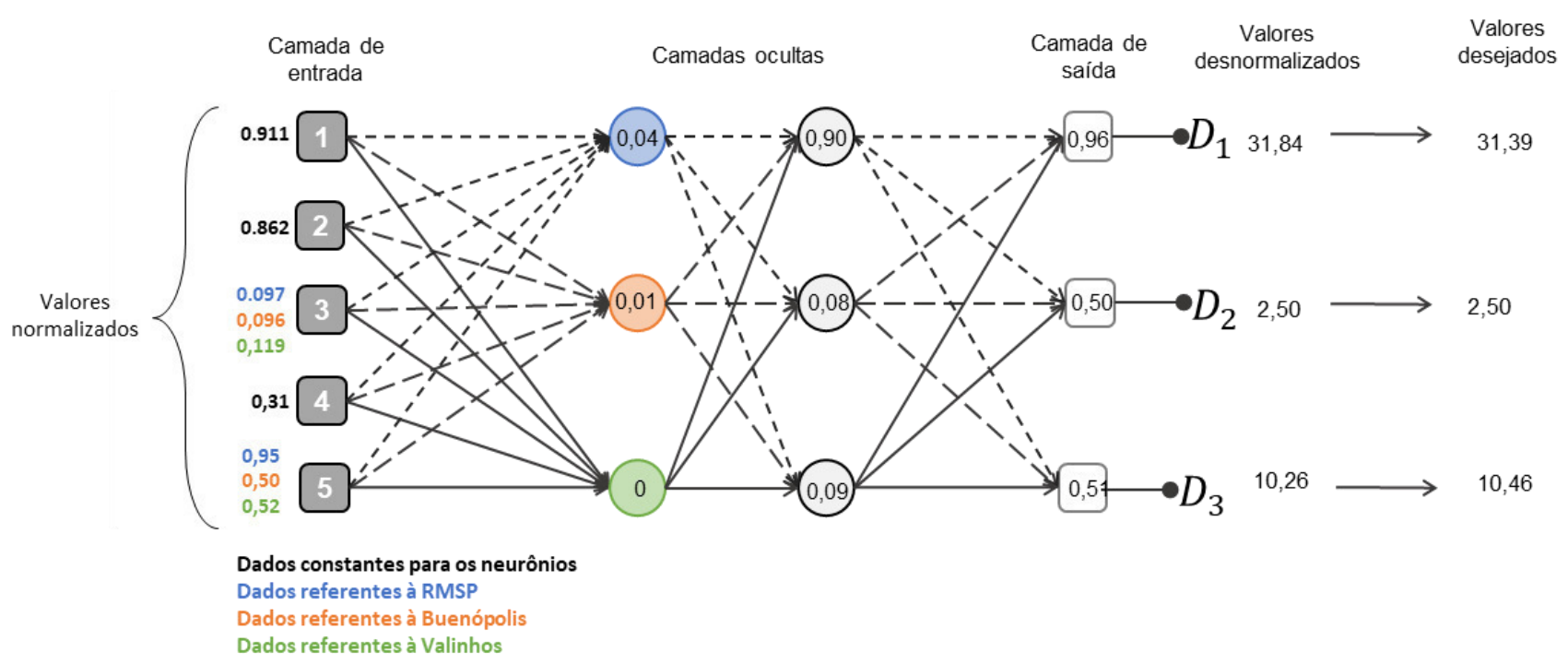

Figura 6.4 - Exemplo de estapas de cálculo da Rede B para um conjunto de dados de entrada.

A Tabela 6.7 mostra os coeficientes de soma quadrática das diferenças (Sq), de correlação (r), raiz do erro quadrático médio (RMSE) e de coeficiente de eficiência de Nash-Sutcliffe, após o treinamento da Rede B. 
Tabela 6.7 - Soma quadrática das diferenças $(\mathrm{Sq})$, correlação $(\mathrm{r})$, raiz do erro quadrático médio (RMSE) e coeficiente de eficiência de Nash-Sutcliffe, entre os resultados da PD (etapa 1) e a Rede B.

\begin{tabular}{ccccc}
\hline & Sq & $r$ & RMSE & NSE \\
\hline Rede B e PD & 0.53 & 0.99 & 0.04 & 0.75 \\
\hline
\end{tabular}

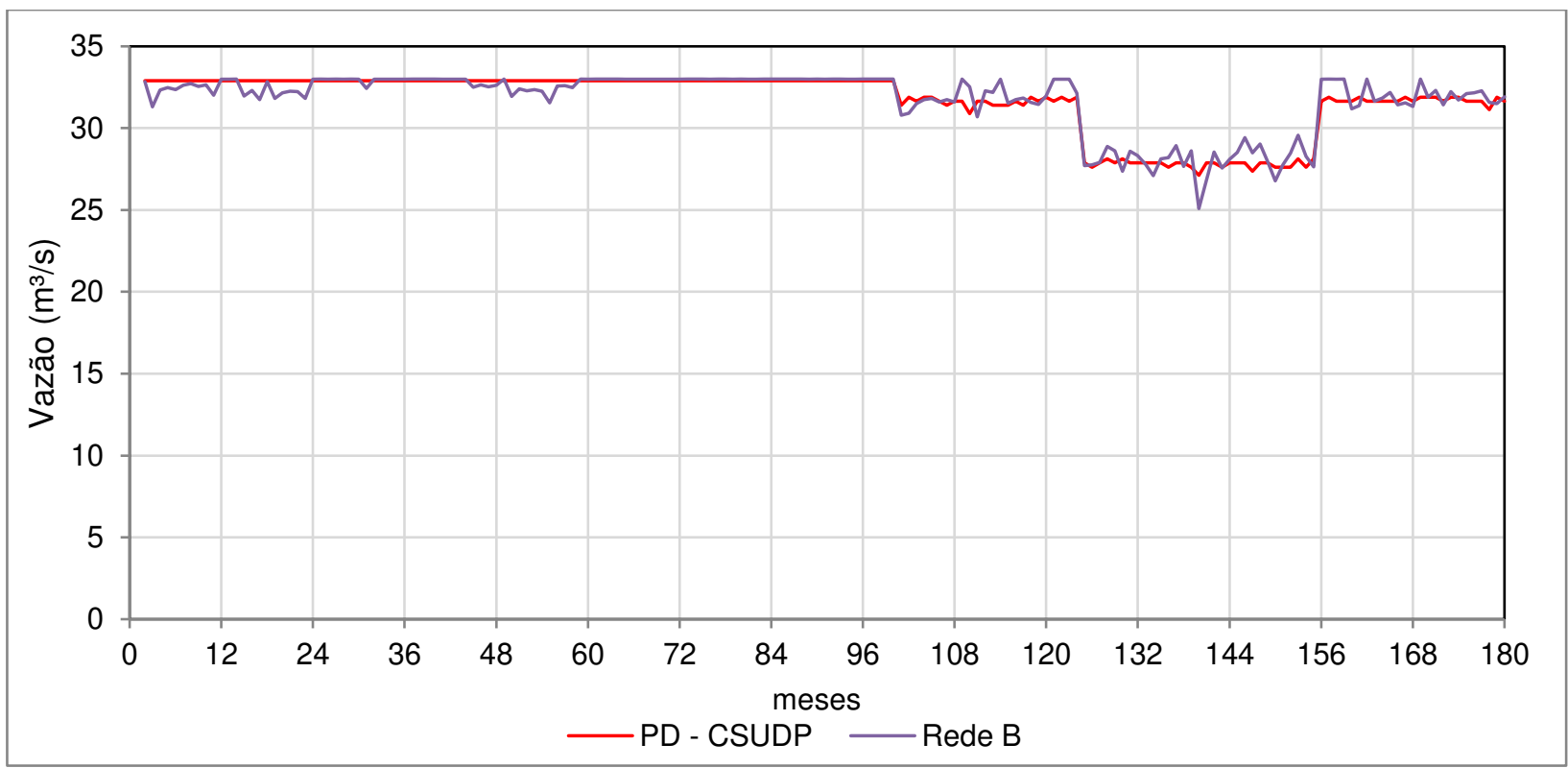

Figura 6.5 - Exemplo de saída da Rede B: Vazões fornecidas para a RMSP comparadas aos respectivos resultados da PD.

Para definição dos valores de demandas requeridas a fim de compor as regras operativas, observou-se os resultados de vazões fornecidas da Rede $B$, em termos das permanências. Os valores requeridos foram relacionados às faixas de operação, a fim de que, quanto maior o volume disponível, maior poderia ser o valor da demanda requerida.

Esta hipótese foi fundamental para a definição das regras de operação, pois a tendência da Rede $B$, é reproduzir o comportamento da PD, cujo caráter determinístico antecipa o período de baixas afluências. O que provoca o efeito contrário ao desejável, isto é, quanto maior o volume disponível, menor a vazão fornecida.

Esta tendência, que foi absorvida pela Rede B, pode ser observada na Figura 6.6 e na Figura 6.7, que mostram respectivamente as permanências das vazões 
fornecidas para RMSP e Buenópolis respectivamente, nas faixas operativas da Regra 1.

Desta maneira, para se obter os valores das demandas requeridas que fossem compatíveis com a quantidade de volume útil acumulada no reservatório, optou-se por compatíveis com as garantias fornecidas pelo modelo de rede neural. Como exemplo, pode-se observar que na Figura 6.6 o menor valor fornecido pela Regra 1 para a RMSP é $26,80 \mathrm{~m} 3 / \mathrm{s}$, com $100 \%$ de garantia. Este valor foi considerado como a demanda mínima requerida para a Regra 1 nesta faixa.

Nas faixas seguintes procedeu-se de maneira análoga, admitindo as menores garantias, porém maiores demandas exigidas, à medida que o reservatório apresentasse maior volume acumulado. Este processo envolveu um critério subjetivo para a melhor distribuição dos valores requeridos entre as faixas intermediárias (faixa 2 e faixa 3$)$.

Com relação à demanda de Buenópolis, a Rede $\mathrm{B}$ forneceu valores muito próximos de vazões mínimas e máximas, de 2,40 m³/s a 2,50 m³/s.

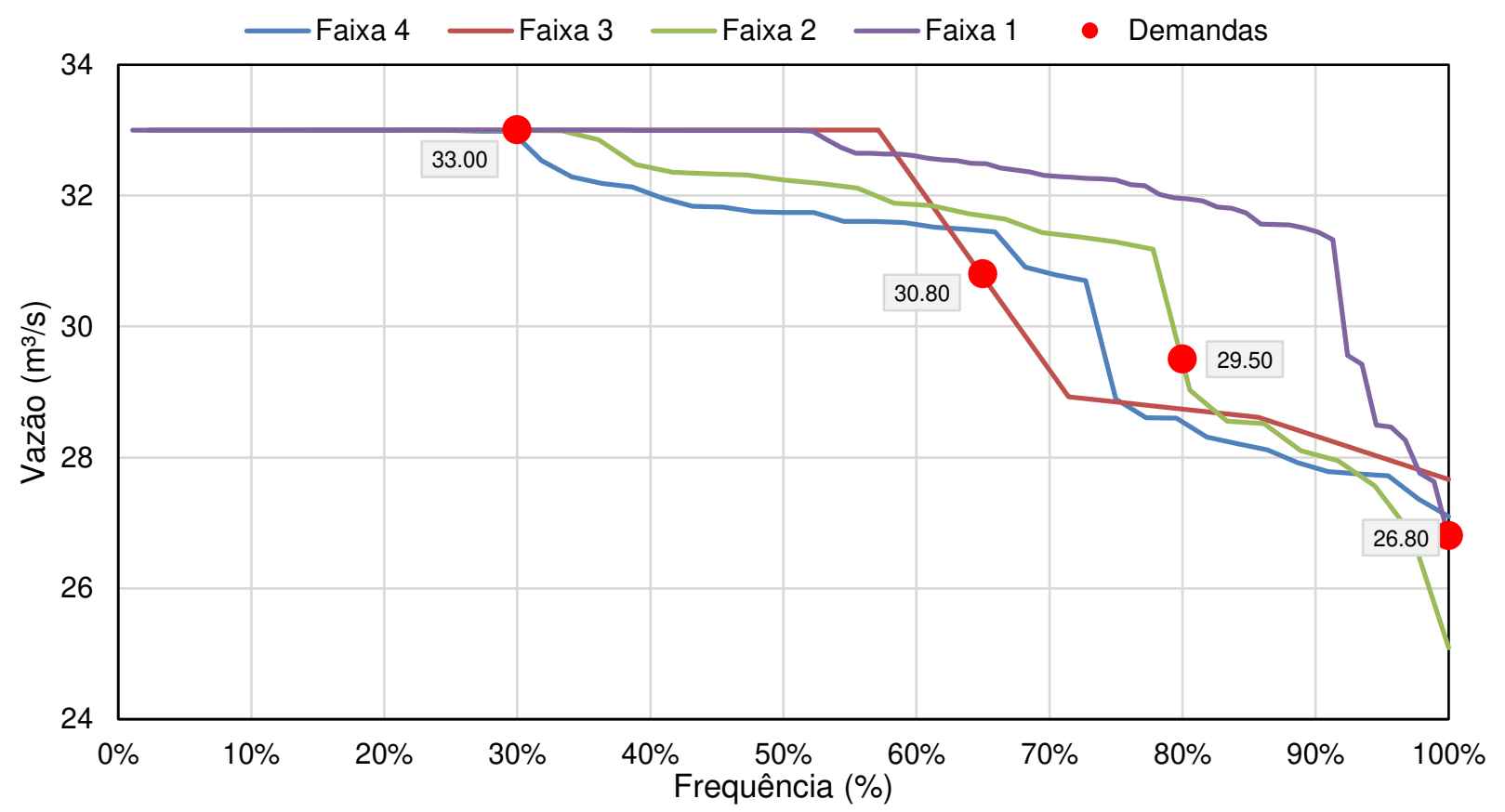

Figura 6.6 - Garantias de atendimento à RMSP da Regra 1, por faixa de operação, obtida por meio da Rede B. 


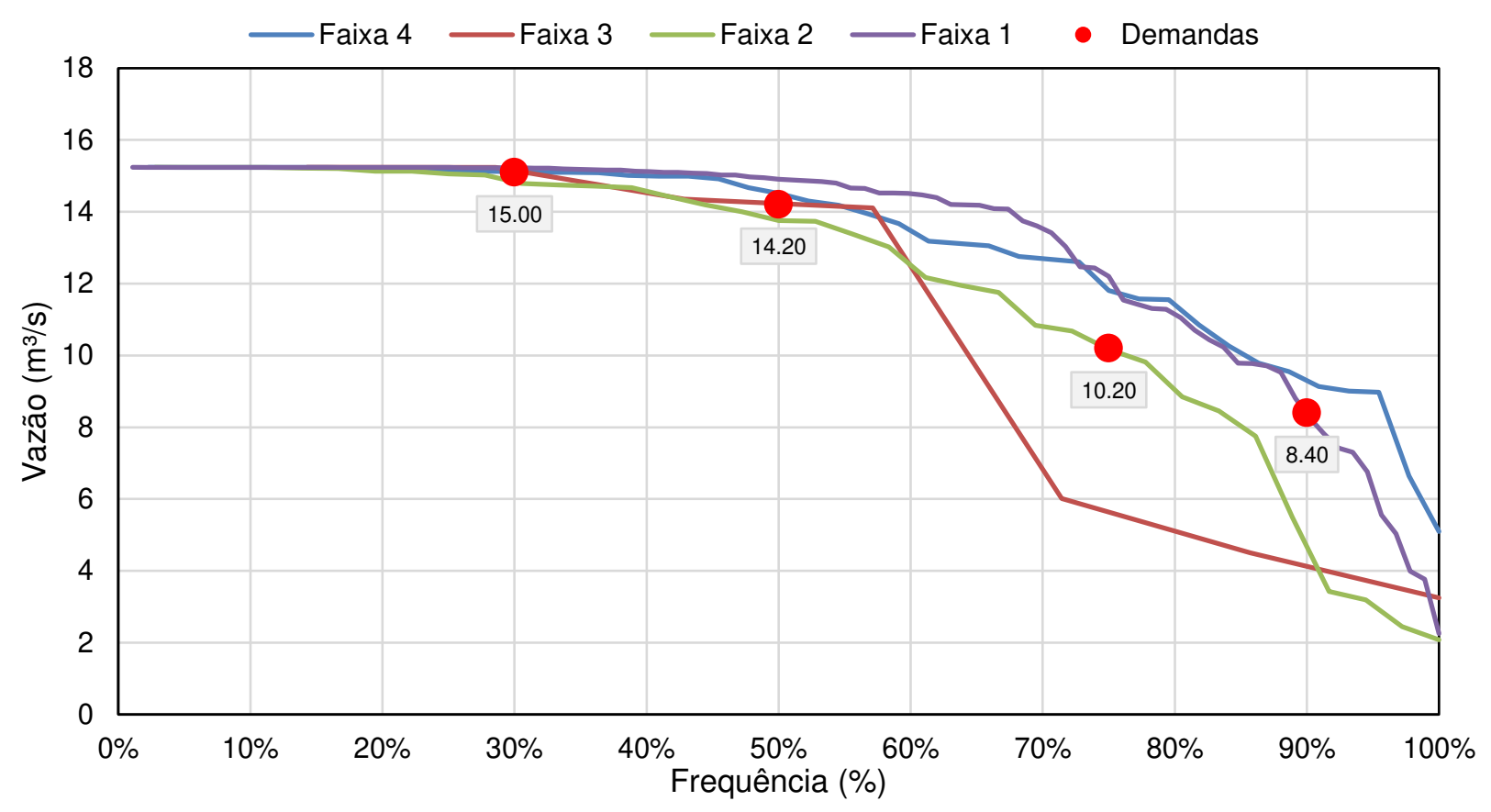

Figura 6.7 - Garantias de atendimento à Valinhos da Regra 1, por faixa de operação, obtida por meio da Rede B.

Procedeu-se a análise de vazões requeridas e as respectivas garantias para os resultados das demais regras, obtendo-se os valores de demanda requerida mostrados no item a seguir.

\subsubsection{Regras de operação por faixas}

$\mathrm{Na}$ Tabela 6.8 são mostradas as regras de operação por faixas, com as demandas requeridas em cada estado hidrológico do sistema.

Tabela 6.8 - Regras de operação por faixas.

\begin{tabular}{c|c|ccc}
\hline \multicolumn{3}{|c}{ Regra 1 - Vazões requeridas $\left(\mathrm{m}^{3} / \mathrm{s}\right)$} \\
\hline Faixa & $\%$ volume & RMSP & Buenópolis & Valinhos \\
\hline Faixa 1 & $0-25 \%$ & 26.80 & 2.40 & 8.40 \\
\hline Faixa 2 & $25 \%-55 \%$ & 29.50 & 2.50 & 10.20 \\
\hline Faixa 3 & $55 \%-70 \%$ & 30.80 & 2.40 & 14.20 \\
\hline Faixa 4 & $70-100 \%$ & 33.00 & 2.50 & 15.10 \\
\hline
\end{tabular}




\begin{tabular}{|c|c|c|c|c|}
\hline \multicolumn{5}{|c|}{ Regra 2 - Vazões requeridas $\left(\mathrm{m}^{3} / \mathrm{s}\right)$} \\
\hline Faixa & $\%$ volume & RMSP & Buenópolis & Valinhos \\
\hline Faixa 1 & $0-15 \%$ & 27.60 & 2.40 & 9.60 \\
\hline Faixa 2 & $15 \%-30 \%$ & 28.70 & 2.50 & 10.50 \\
\hline Faixa 3 & $30 \%-60 \%$ & 31.30 & 2.50 & 13.50 \\
\hline Faixa 4 & $60 \%-100 \%$ & 33.00 & 2.50 & 15.00 \\
\hline \multicolumn{5}{|c|}{ Regra 3 - Vazões requeridas $\left(\mathrm{m}^{3} / \mathrm{s}\right)$} \\
\hline Faixa & $\%$ volume & RMSP & Buenópolis & Valinhos \\
\hline Faixa 1 & $0-15 \%$ & 27.60 & 2.40 & 9.00 \\
\hline Faixa 2 & $15 \%-30 \%$ & 28.90 & 2.50 & 9.00 \\
\hline Faixa 3 & $30 \%-50 \%$ & 31.20 & 2.50 & 11.00 \\
\hline Faixa 4 & $50 \%-60 \%$ & 32.10 & 2.50 & 14.00 \\
\hline Faixa 5 & $60 \%-100 \%$ & 33.00 & 2.50 & 15.00 \\
\hline \multicolumn{5}{|c|}{ Regra 4 - Vazões requeridas $\left(\mathrm{m}^{3} / \mathrm{s}\right)$} \\
\hline Faixa & $\%$ volume & RMSP & Buenópolis & Valinhos \\
\hline Faixa 1 & $0-20 \%$ & 27.60 & 2.40 & 8.20 \\
\hline Faixa 2 & $20 \%-30 \%$ & 29.30 & 2.50 & 9.70 \\
\hline Faixa 3 & $30 \%-40 \%$ & 31.10 & 2.50 & 11.80 \\
\hline Faixa 4 & $40 \%-60 \%$ & 31.90 & 2.50 & 14.10 \\
\hline Faixa 5 & $60-100 \%$ & 33.00 & 2.50 & 15.00 \\
\hline
\end{tabular}

\subsection{ETAPA 3 - SIMULAÇÃO}

Os resultados das regras operativas são apresentados individualmente, em termos dos volumes finais armazenados no $\mathrm{RE}$, e das permanências de atendimento às demandas. Em seguida parâmetros acerca do desempenho das regras são comparados.

\subsubsection{Regra 1}

A Figura 6.8 e a Figura 6.9 mostram respectivamente os resultados obtidos com a Regra 1 para os volumes finais armazenados no RE, e as curvas de permanência das vazões fornecidas para as demandas RMSP, Valinhos e Buenópolis. 


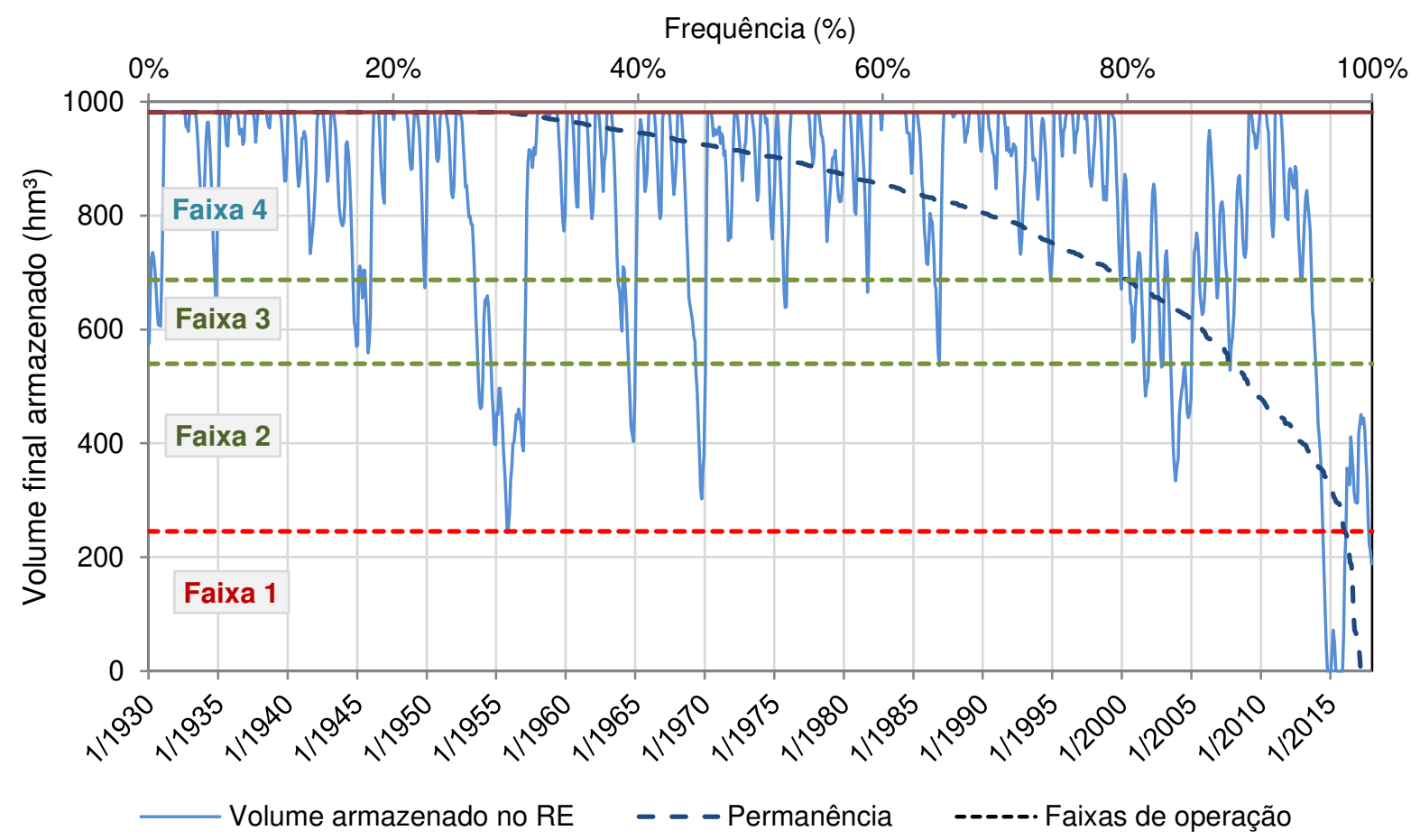

Figura 6.8 - Regra 1: volumes finais armazenados no RE e sua permanência.

Pode-se observar na curva de permanência dos volumes o percentual de tempo em que o RE permaneceu em cada faixa de operação, com relação ao período todo. Durante $80 \%$ do período o RE apresenta volume útil acumulado acima de $70 \%$ de sua capacidade, operando na Faixa 4. Durante $8 \%, 9 \%$ e $2 \%$ do período analisado, o sistema opera respectivamente nas Faixas 3, 2 e 1. 


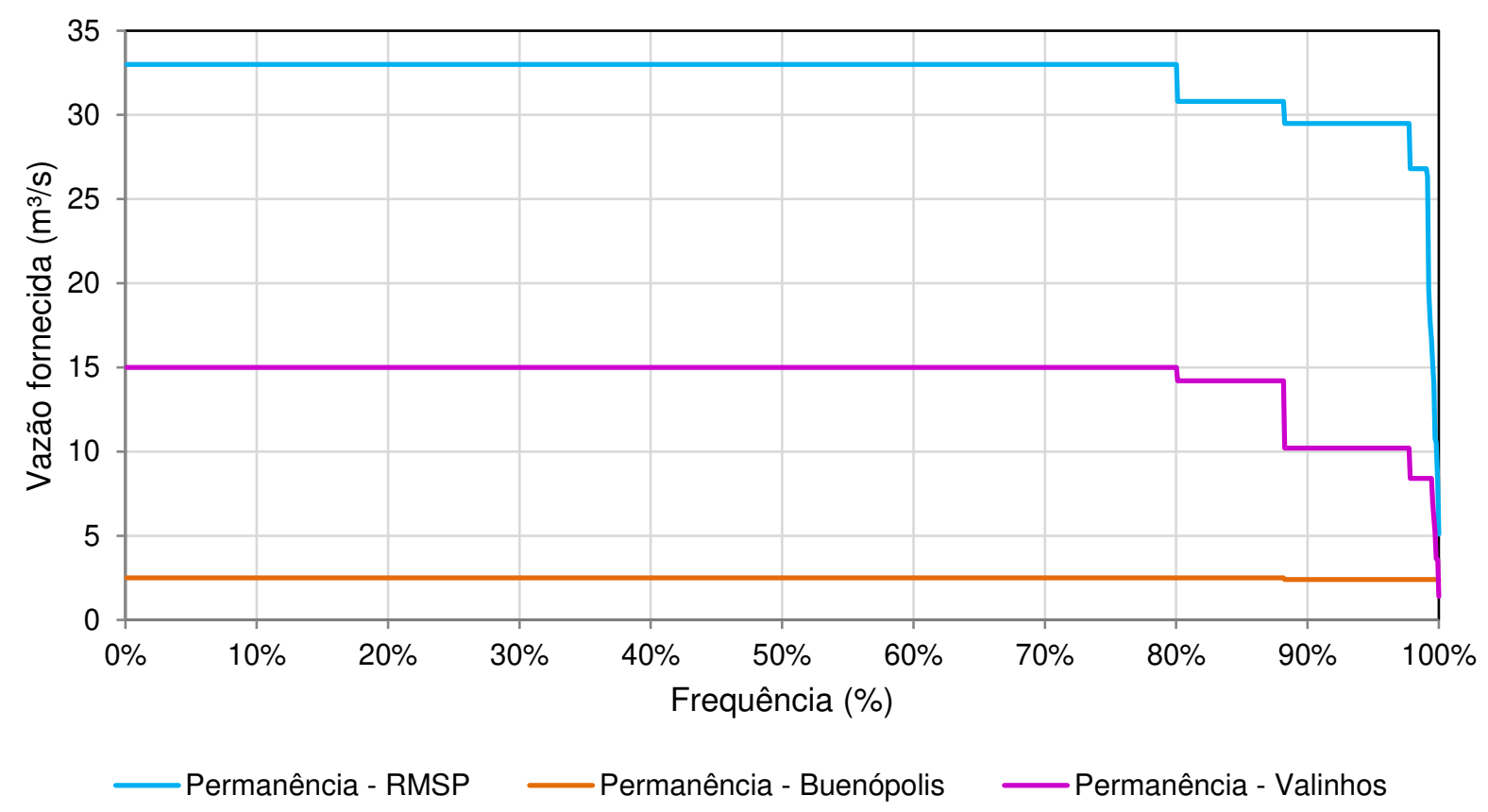

Figura 6.9 - Regra 1: Fornecimento de vazões às demandas da RMSP, de Buenópolis e Valinhos.

Com relação ao fornecimento de vazões para as demandas, a regra apresentou bom desempenho. Para Buenópolis a Regra 1 forneceu o valor de 2,5 m³/s com 96\% de garantia, e vazões mínimas de 2,4 m³/s. Para Valinhos, o modelo atendeu $15 \mathrm{~m}^{3} / \mathrm{s}$ durante $80 \%$ do período, e vazões mínimas de $1,4 \mathrm{~m} 3 / \mathrm{s}$. Apesar dos déficits, o modelo forneceu vazões superiores a $7 \mathrm{~m} 3 / \mathrm{s}$ durante $99 \%$ do período.

A RMSP foi atendida com $33 \mathrm{~m} 3 / \mathrm{s}$ durante $80 \%$ do período, e com vazões superiores a $16,7 \mathrm{~m}^{3} / \mathrm{s}$ durante $99 \%$ do período. As vazões mínimas chegaram a 5,1 $\mathrm{m}^{3} / \mathrm{s}$.

\subsubsection{Regra 2}

A Figura 6.10 e a Figura 6.11 mostram respectivamente os resultados obtidos com a Regra 2 para os volumes finais armazenados no RE, e as curvas de permanência das vazões fornecidas para as demandas RMSP, Valinhos e Buenópolis. 


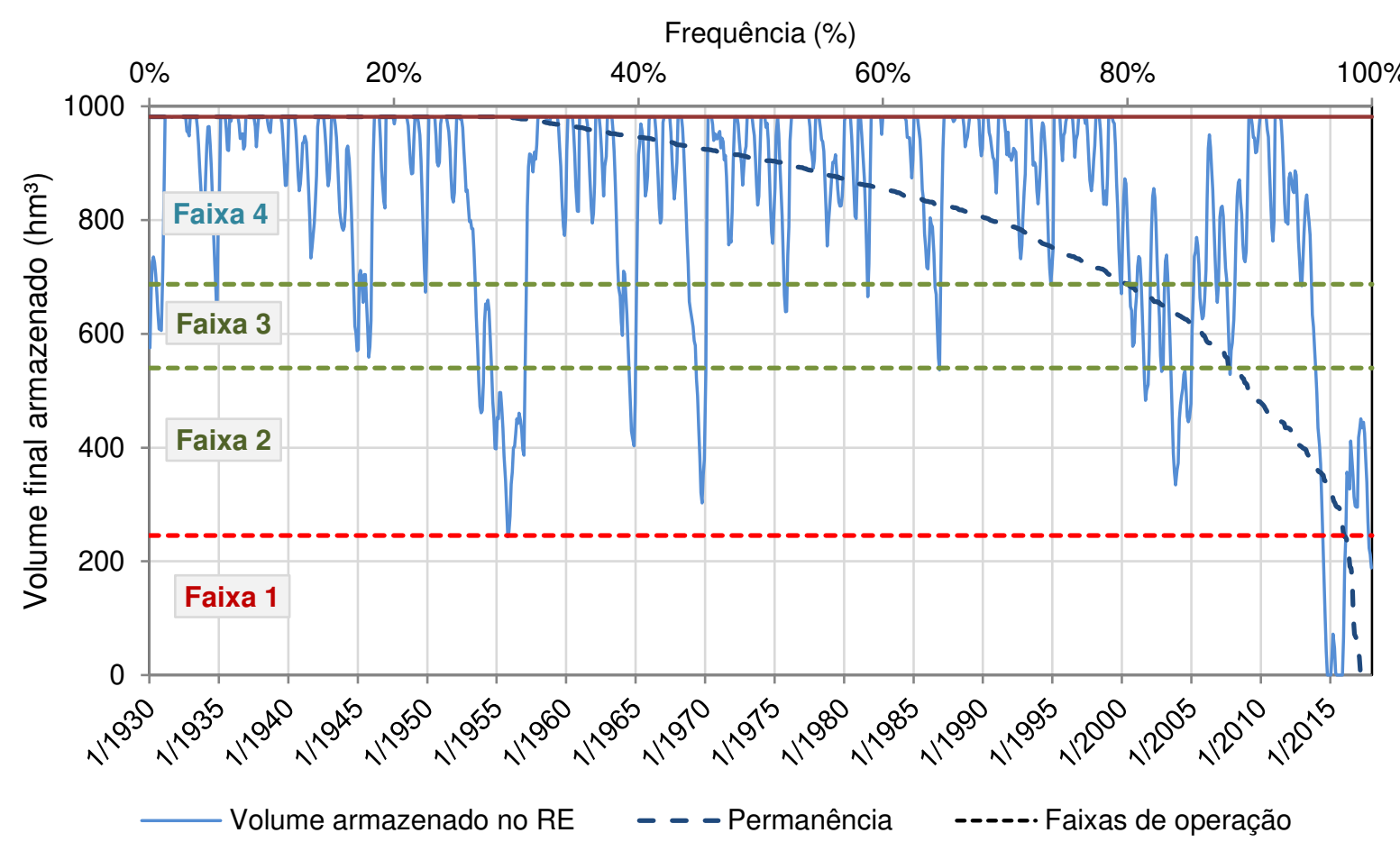

Figura 6.10 - Regra 2: volumes finais armazenados no RE e sua permanência.

Pode-se observar na curva de permanência dos volumes o percentual de tempo em que o RE permaneceu em cada faixa de operação, com relação ao período todo. Durante $80 \%$ do período o RE apresenta volume útil acumulado acima de $60 \%$ de sua capacidade, operando na Faixa 4. Durante $8 \%$, $9 \%$ e $2 \%$ do período analisado, o sistema opera respectivamente nas Faixas 3, 2 e 1. 


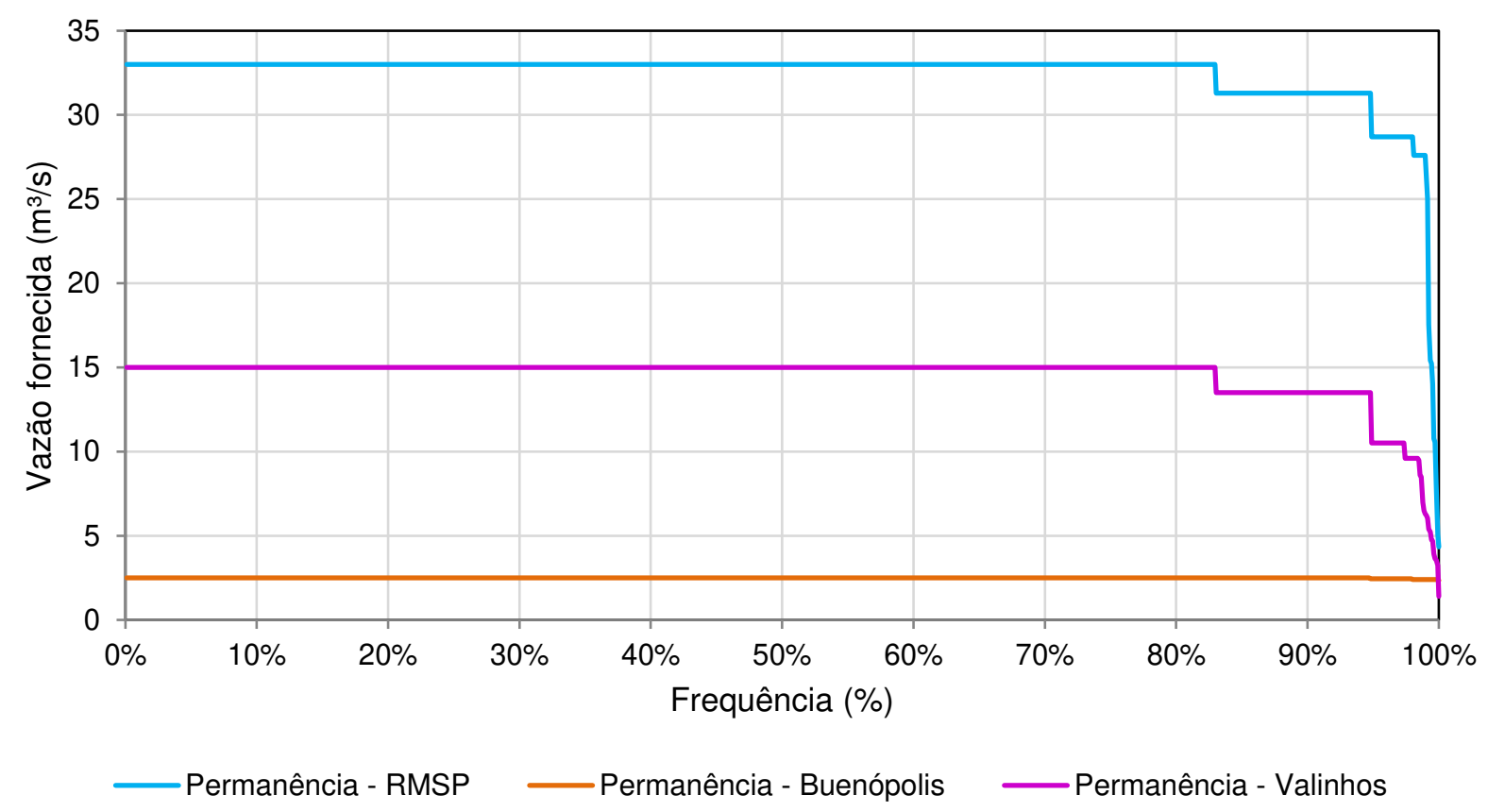

Figura 6.11 - Regra 2: Fornecimento de vazões às demandas da RMSP, de Buenópolis e Valinhos.

Com relação ao fornecimento de vazões para Buenópolis a Regra 2 forneceu o valor de $2,5 \mathrm{~m}^{3} / \mathrm{s}$ com $98 \%$ de garantia, e vazões mínimas de $2,4 \mathrm{~m} 3 / \mathrm{s}$. Para Valinhos, o modelo atendeu $15 \mathrm{~m}^{3} / \mathrm{s}$ durante $83 \%$ do período, e vazões mínimas de $1,4 \mathrm{~m}^{3} / \mathrm{s}$. O modelo forneceu vazões superiores a $4,75 \mathrm{~m}^{3} / \mathrm{s}$ durante $99 \%$ do período.

A RMSP foi atendida com $33 \mathrm{~m}^{3} / \mathrm{s}$ durante $83 \%$ do período, e com vazões superiores a $15,2 \mathrm{~m} 3 / \mathrm{s}$ durante $99 \%$ do período. As vazões mínimas chegaram a 4,3 $\mathrm{m}^{3} / \mathrm{s}$.

\subsubsection{Regra 3}

A Figura 6.12 e a Figura 6.13 mostram respectivamente os resultados obtidos com a Regra 2 para os volumes finais armazenados no RE, e as curvas de permanência das vazões fornecidas para as demandas RMSP, Valinhos e Buenópolis. 


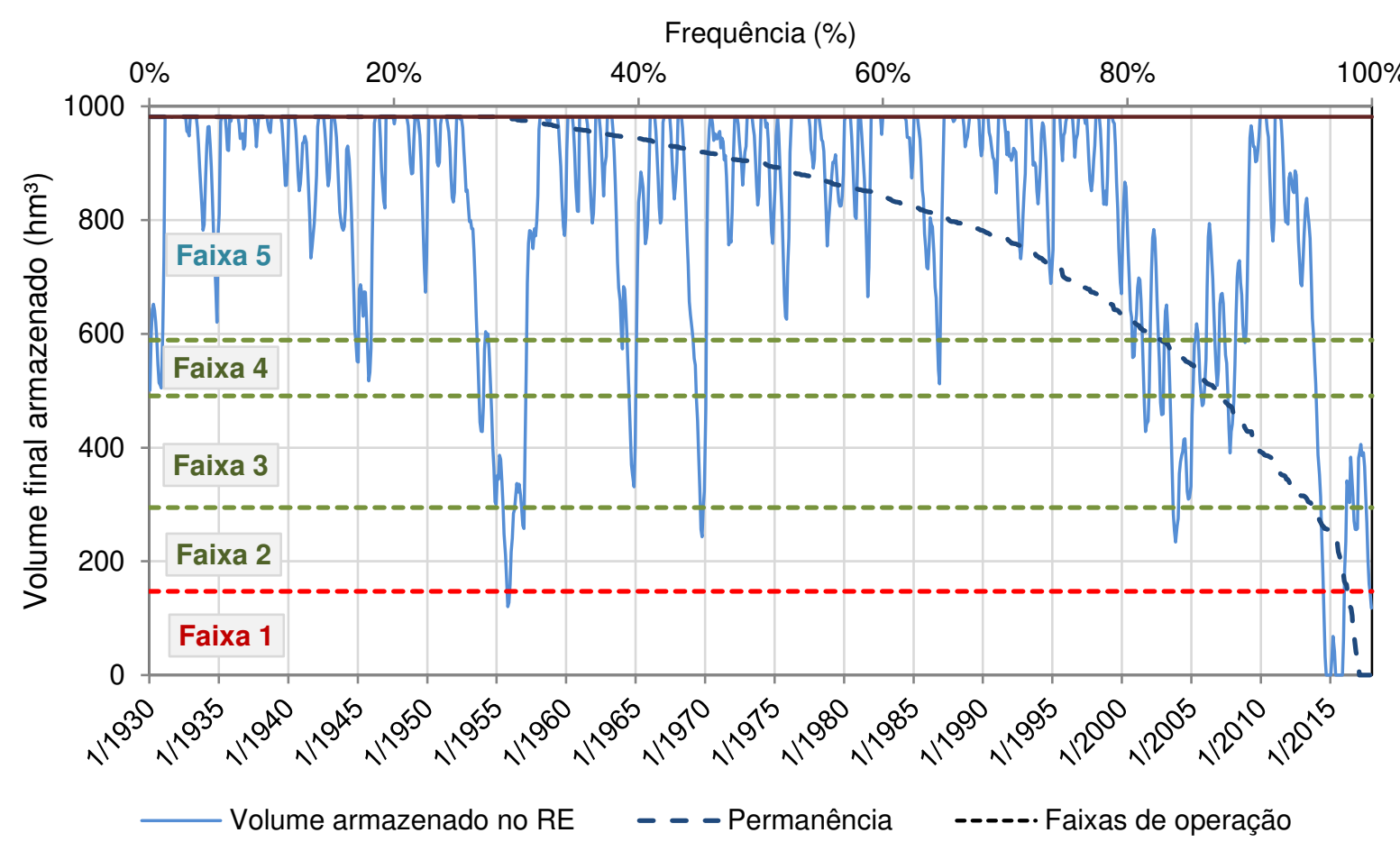

Figura 6.12 - Regra 3: volumes finais armazenados no RE e sua permanência.

Pode-se observar na curva de permanência dos volumes o percentual de tempo em que o RE permaneceu em cada faixa de operação, com relação ao período todo. Durante $83 \%$ do período o RE apresenta volume útil acumulado acima de $60 \%$ de sua capacidade, operando na Faixa 5. Durante 5\%, 7\% e 2\% do período analisado, o sistema opera respectivamente nas Faixas 4, 3 e 2. O RE opera na faixa 1, mais restritiva durante apenas $2 \%$ do período. 


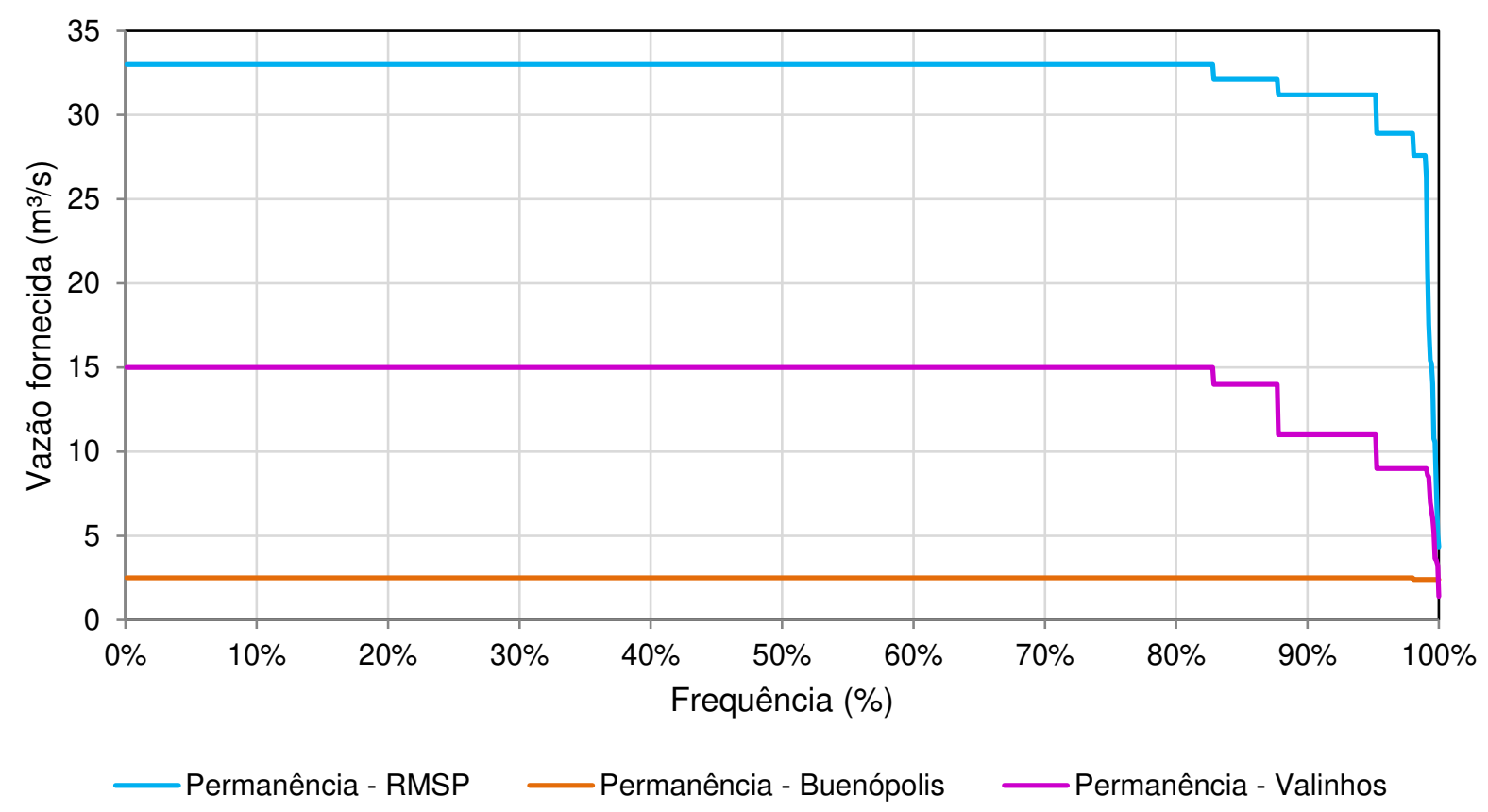

Figura 6.13 - Regra 3: Fornecimento de vazões às demandas da RMSP, de Buenópolis e Valinhos.

Com relação ao fornecimento de vazões para as demandas, a Regra 3 forneceu o valor de $2,5 \mathrm{~m}^{3} / \mathrm{s}$ com $98 \%$ de garantia, e vazões mínimas de $2,4 \mathrm{~m}^{3} / \mathrm{s}$ para Buenópolis. Para Valinhos, o modelo teve desempenho semelhante ao da Regra 2, porém com vazões superiores a $6,5 \mathrm{~m} 3 / \mathrm{s}$ durante $99 \%$ do período.

Com relação ao atendimento da RMSP, o modelo teve as mesmas características da Regra 2.

\subsubsection{Regra 4}

A Figura 6.14 e a Figura 6.15 mostram respectivamente os resultados obtidos com a Regra 2 para os volumes finais armazenados no RE, e as curvas de permanência das vazões fornecidas para as demandas RMSP, Valinhos e Buenópolis. 


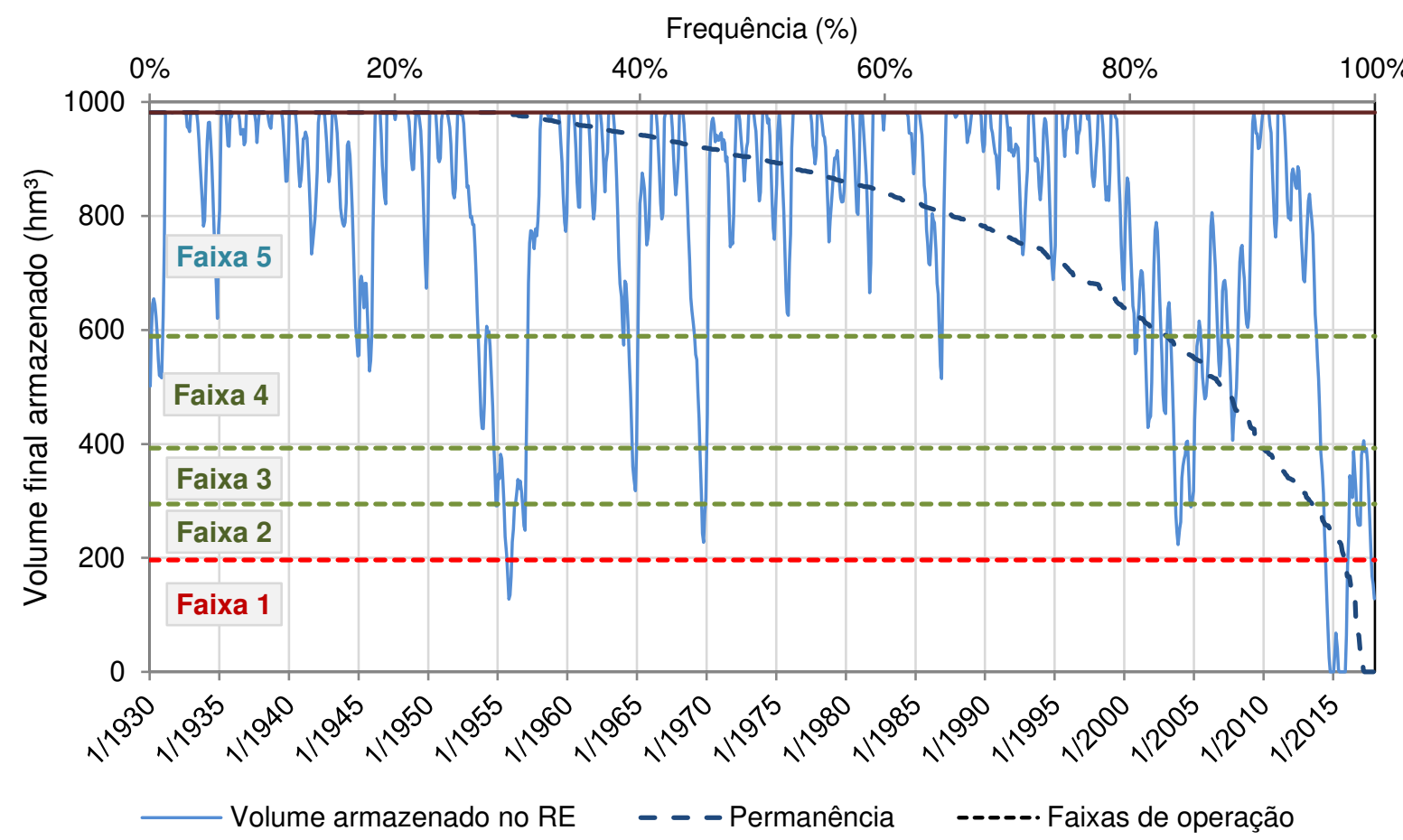

Figura 6.14 - Regra 4: volumes finais armazenados no RE e sua permanência.

Os resultados em termos de volumes finais armazenados para a Regra 4 foram muito semelhantes aos resultados da Regra 3.

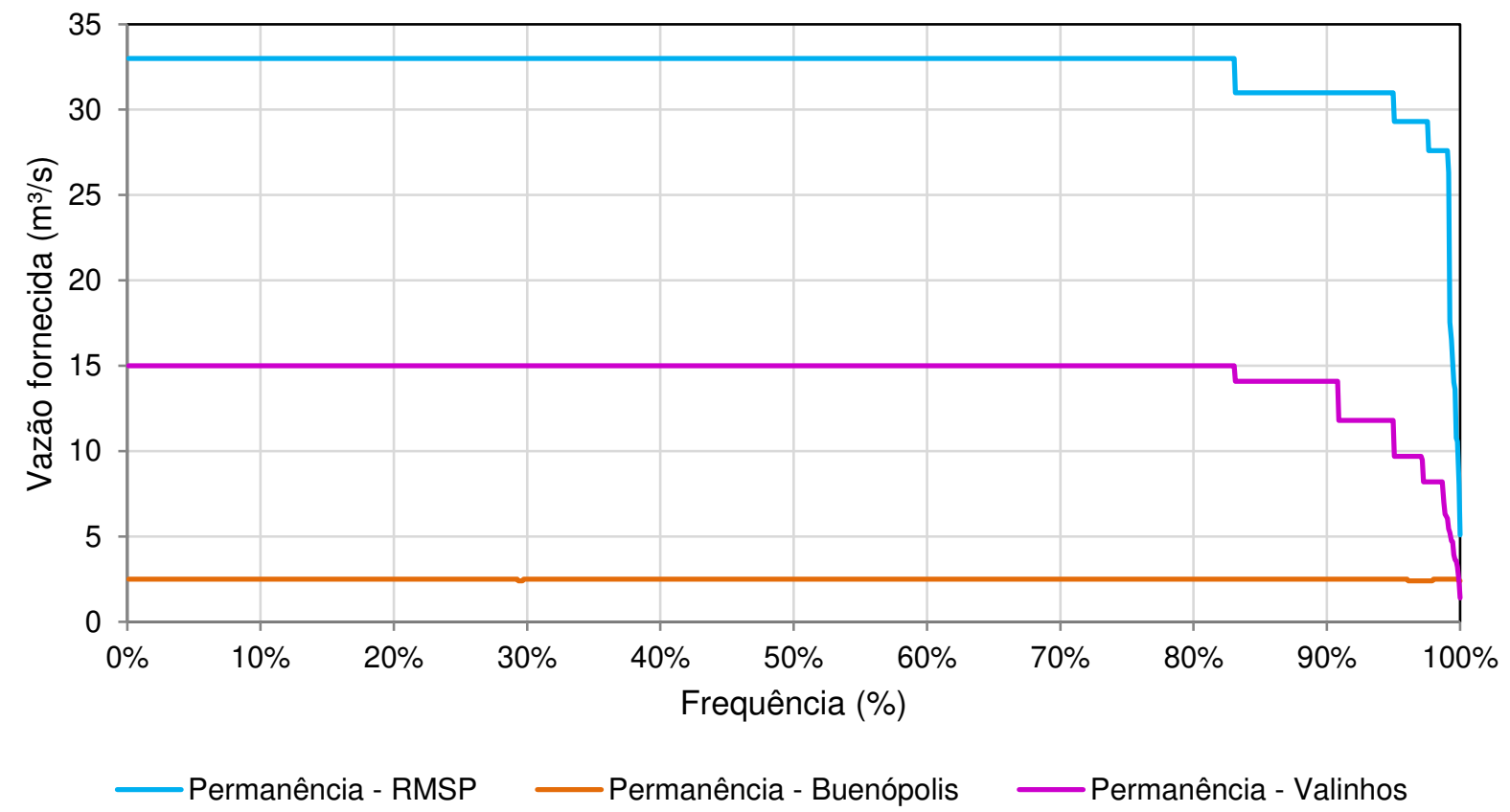

Figura 6.15 - Regra 4: Fornecimento de vazões às demandas da RMSP, de Buenópolis e Valinhos. 
Com relação ao fornecimento de vazões para as demandas, a regra apresentou bom desempenho. Para Buenópolis a Regra 1 forneceu o valor de 2,5 m³/s com 96\% de garantia, e vazões mínimas de 2,4 m³/s. Para Valinhos, o modelo atendeu $15 \mathrm{~m}^{3} / \mathrm{s}$ durante $86 \%$ do período, e vazões mínimas de $1,4 \mathrm{~m}^{3} / \mathrm{s}$. O modelo forneceu vazões superiores a $4,7 \mathrm{~m}^{3} / \mathrm{s}$ durante $99 \%$ do período.

A RMSP foi atendida com $33 \mathrm{~m}^{3} / \mathrm{s}$ durante $83 \%$ do período, e com vazões superiores a $15,2 \mathrm{~m}^{3} / \mathrm{s}$ durante $99 \%$ do período. As vazões mínimas chegaram a 5,1 $\mathrm{m}^{3} / \mathrm{s}$.

A configuração da Regra 4 é de particular interesse, devido às faixas de operação, análogas à regra operativa atual do SC, apesar de não ter sido considerados os diferentes períodos relativos à umidade. No entanto, observa-se que a regra vigente possui demandas requeridas mais conservadoras do que a obtida para a Regra 4, conforme pode-se observar na Tabela 6.9.

Tabela 6.9 - Regra de operação vigente do SC e Regra 4.

\begin{tabular}{c:c|ccc}
\hline \multicolumn{3}{c}{ Regra vigente - Vazões requeridas (m³) } \\
Faixa & $\%$ volume & RMSP & Buenópolis & Valinhos \\
\hline Faixa 1 & $0-20 \%$ & 15,50 & 2 & $10 / 10^{*}$ \\
\hline Faixa 2 & $20 \%-30 \%$ & 23 & 2 & $13 / 10^{*}$ \\
\hdashline Faixa 3 & $30 \%-40 \%$ & 27 & 2 & $13 / 10^{*}$ \\
\hline Faixa 4 & $40 \%-60 \%$ & 31 & $2,5 / 2^{*}$ & $15 / 10^{*}$ \\
\hline Faixa 5 & $60 \%-100 \%$ & 33 & $2,5 / 2^{*}$ & $15 / 10^{*}$ \\
\hline
\end{tabular}

*Demanda requerida para o período seco.

\begin{tabular}{c|c|ccc}
\hline Faixa & $\%$ volume & RMSP & Buenópolis & Valinhos \\
\hline Faixa 1 & $0-20 \%$ & 27.60 & 2.40 & 8.20 \\
\hline Faixa 2 & $20 \%-30 \%$ & 29.30 & 2.50 & 9.70 \\
\hline Faixa 3 & $30 \%-40 \%$ & 31.10 & 2.50 & 11.80 \\
\hline Faixa 4 & $40 \%-60 \%$ & 31.90 & 2.50 & 14.10 \\
\hline Faixa 5 & $60-100 \%$ & 33.00 & 2.50 & 15.00 \\
\hline
\end{tabular}

É possível inferir as garantias de atendimento da regra vigente, baseadas nas curvas de permanência da Regra 4 para fins de análise prática.

Observa-se que a regra vigente possui demandas requeridas mais conservadoras do que a obtida para a Regra 4, o que indica maior garantia assegurada e possivelmente, menor estresse do reservatório. 
A Regra 4 foi simulada alterando-se os valores das demandas requeridas para os valores da regra vigente (considerando-se as demandas do período úmido) e os resultados são mostrados na Figura 6.16 e na Figura 6.17.

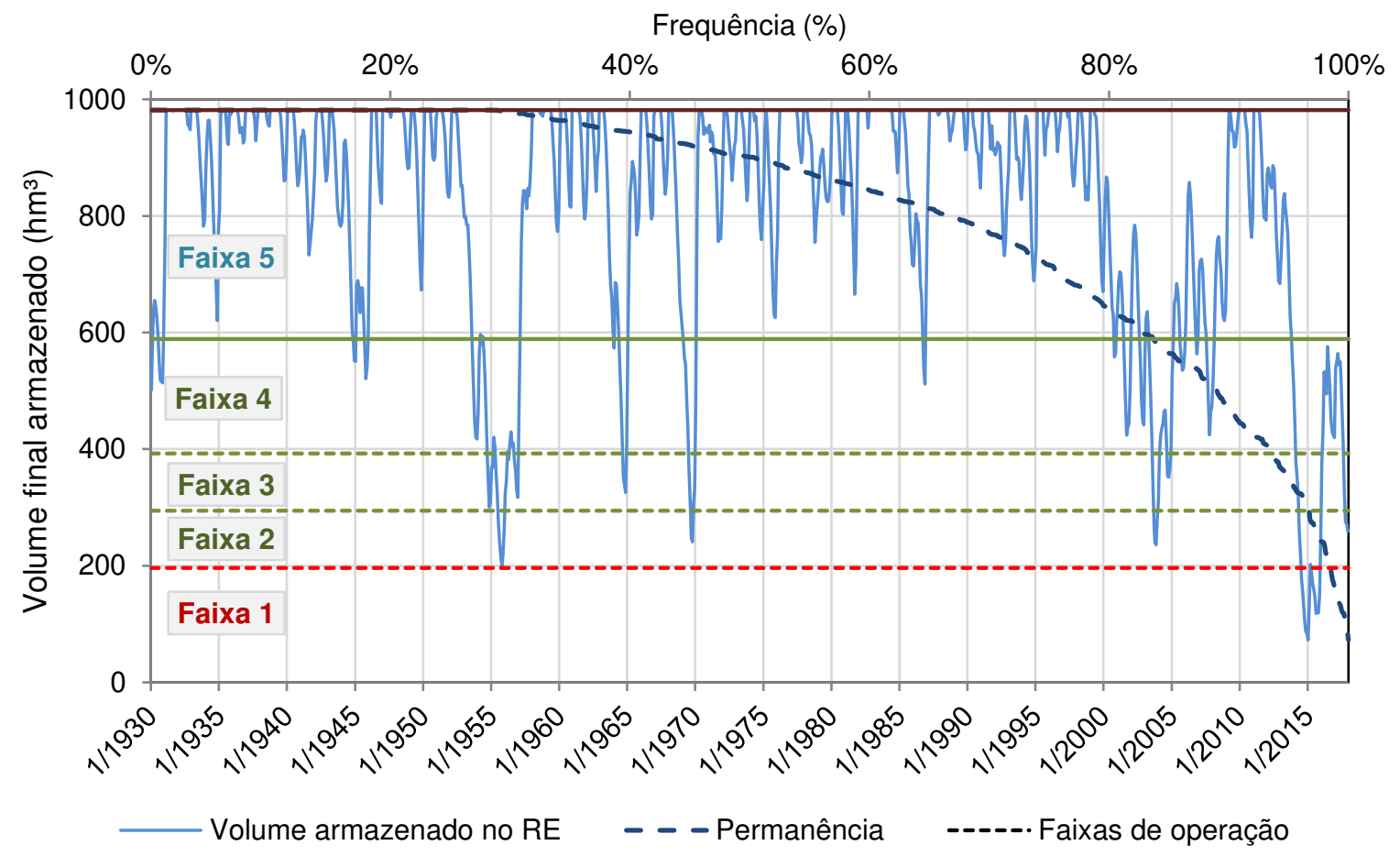

Figura 6.16 - Regra 4: volumes finais armazenados no RE e sua permanência.

A simulação mostra que diferentemente das demais regras operativas formuladas, o RE não sofreu esgotamento da sua capacidade. Este resultado mostra que as menores vazões para as demandas, em especial da demanda da RMSP, possuem grande impactos sobre a conservação do volume do sistema. Além disso, o $\mathrm{RE}$ tende a permanecer em faixas de operação menos restritas, durante a operação.

Em particular, observa-se as faixas 2 e 3, nas quais ocorre grande diferença entre os valores requeridos para a demanda da RMSP pela Regra 4 e pela regra vigente. $O$ efeito das menores demandas requeridas nestas faixas de operação pode facilitar a preservação do volume útil no sistema. 


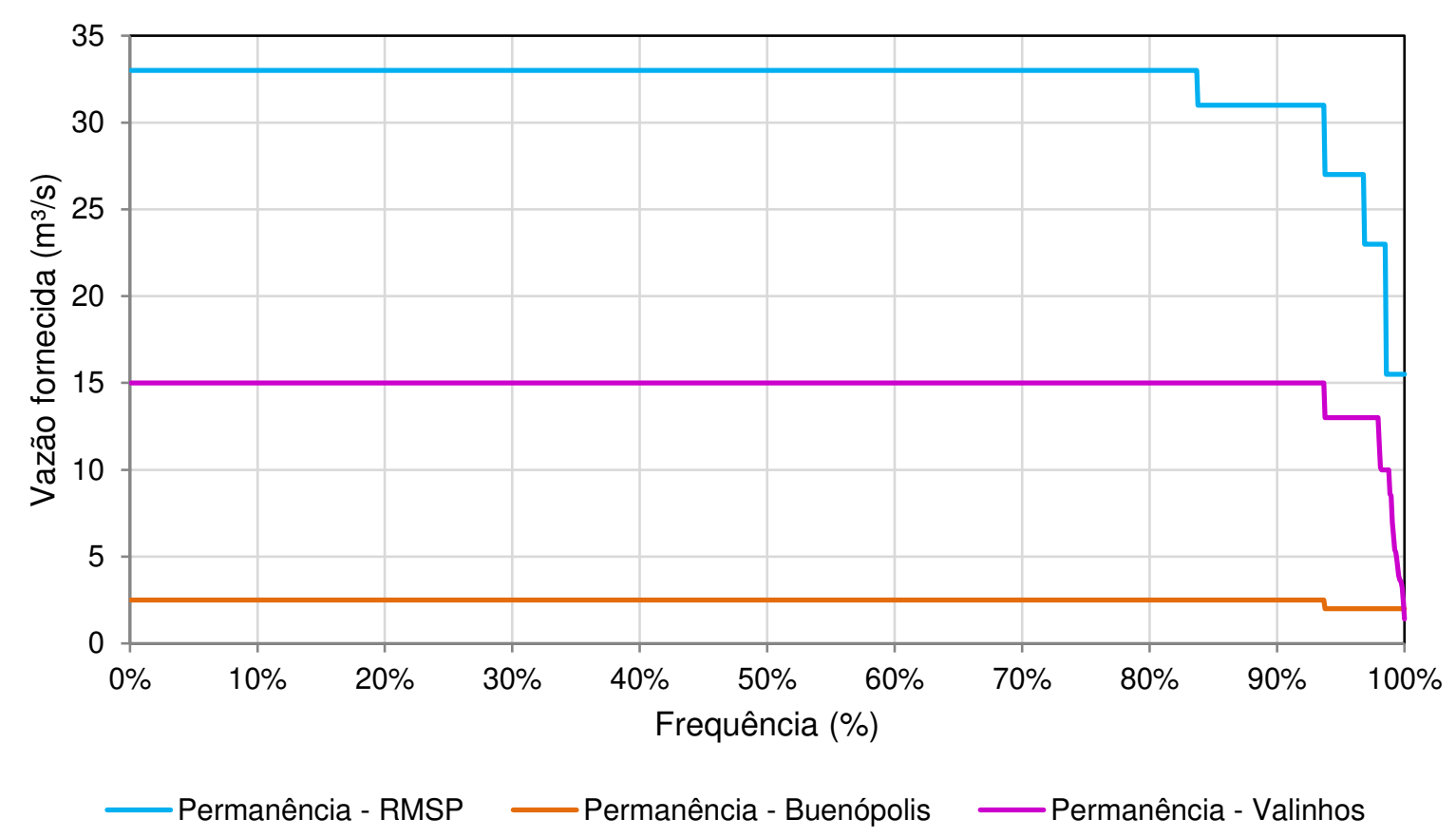

Figura 6.17 - Regra 4: Fornecimento de vazões às demandas da RMSP, de Buenópolis e Valinhos.

As elevadas garantias de atendimento mostradas na Figura 6.17 mostram que, de fato, nesta simulação o RE permaneceu maior tempo em faixas de operação com elevada disponibilidade de volumes, podendo atender $33 \mathrm{~m} / \mathrm{s}$ para a RMSP, $15 \mathrm{~m}^{3} / \mathrm{s}$ para Valinhos e $2,5 \mathrm{~m} 3 / \mathrm{s}$ para Buenópolis com $84 \%, 94 \%$ e $93 \%$ de garantia, respectivamente.

\subsubsection{Desempenho das regras operativas}

Os resultados comparativos de desempenho das regras fornecem subsídios para analisar os múltiplos aspectos envolvidos na determinação da melhor regra operativa para o Sistema Cantareira. Para tanto foram analisadas as curvas de permanência dos volumes, e aspectos gerais de atendimento às demandas do sistema.

Em geral a operação baseada na Regra 1 manteve o sistema com um volume armazenado maior do que as demais regras durante a série, como mostra a Figura 6.18. 


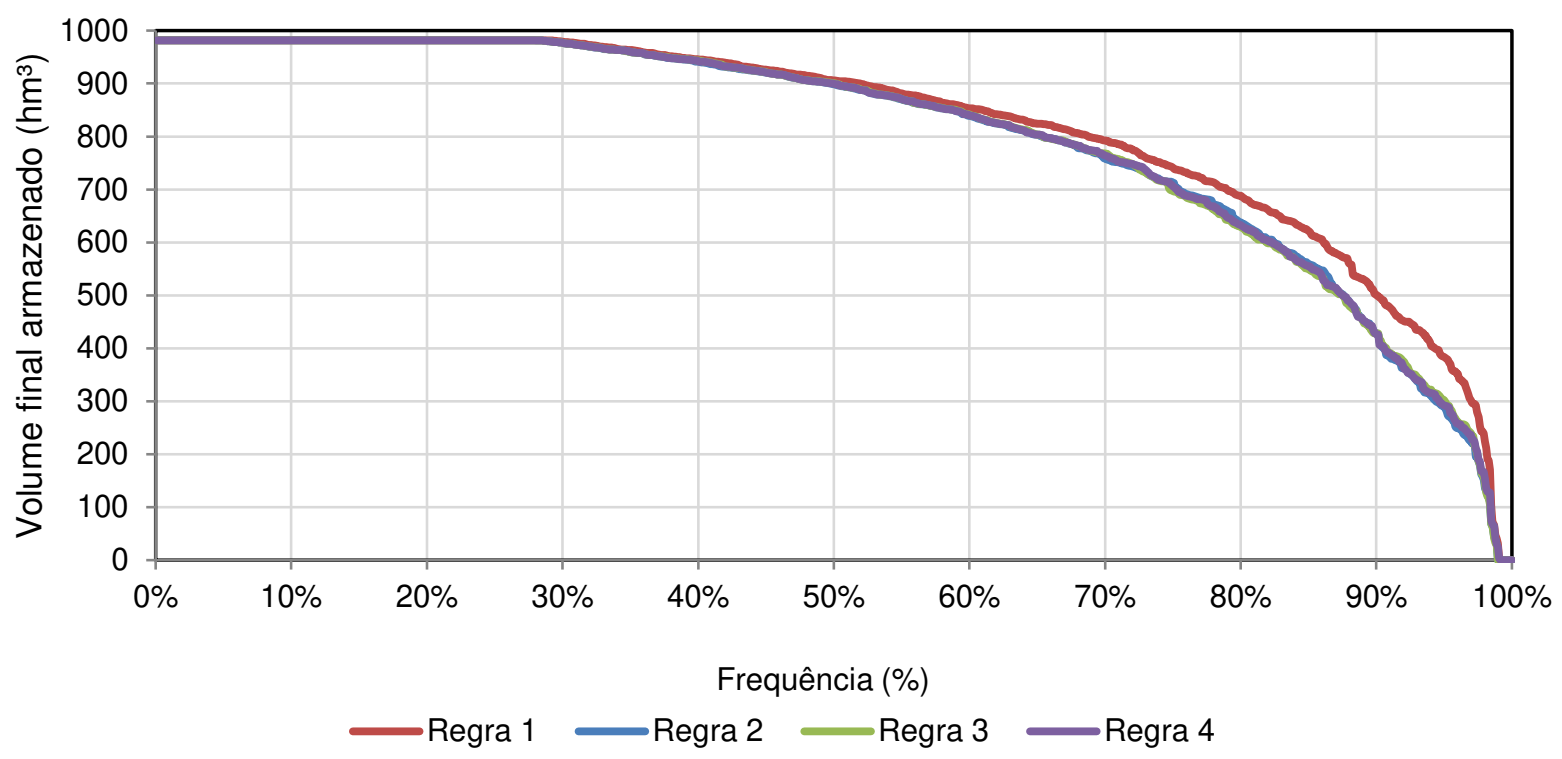

Figura 6.18 - Comparação das curvas de permanência dos volume finais armazenados pelo RE pelas regras operativas.

As curvas de permanência dos volumes armazenados para as Regras 2, 3 e 4 são muito próximas. Este resultado indica que a configuração das faixas operativas da regra 1 pode ser mais favorável em termos da manutenção de volumes elevados, do que a configuração das faixas operativas das demais regras.

$\mathrm{Na}$ Tabela 6.10 são mostrados os resultados comparativos quanto ao número de meses consecutivos nas faixas de operação, e quanto ao número de meses com volume esgotado.

Tabela 6.10 - Maior número de meses consecutivos em determinada nas faixas de operação.

\begin{tabular}{c|c|c|c|c}
\hline & № de meses consecutivos nas faixas de operação & \\
\hline & Regra 1 & Regra 2 & Regra 3 & Regra 4 \\
\hline Faixa 1 & 21 & 18 & 20 & 20 \\
\hline Faixa 2 & 19 & 5 & 5 & 5 \\
\hline Faixa 3 & 16 & 9 & 6 & 6 \\
\hline Faixa 4 & 80 & 200 & 9 & 9 \\
\hline Faixa 5 & - & - & 200 & 200 \\
\hline № de meses & Regra 1 & Regra 2 & Regra 3 & Regra 4 \\
com volume = 0 & 10 & 12 & 12 & 10 \\
\hline
\end{tabular}

Pela comparação de número de meses consecutivos nas faixas de operação 2 e 3, pode-se perceber que as configurações das regras 2, 3 e 4, são menos 
significativas do que a faixa 1 e a faixa 4 . A Regra 1 no entanto, apresenta maior número de meses consecutivos nas faixas de operação 2 e 3 , o que pode explicar a maior permanência dos volumes mostrada na Figura 6.18.

Do ponto de vista do menor número de meses com o reservatório seco, as regras 1 e 4 são mais efetivas do que as regras 2 e 3 .

A Tabela 6.11 mostra os resultados dos valores médios fornecidos às demandas.

Tabela 6.11 - Resultados comparativos das regras com relação aos valores médios de vazões fornecidas às demandas $\left(\mathrm{m}^{3} / \mathrm{s}\right)$.

\begin{tabular}{|c|c|c|c|c|}
\hline $\begin{array}{c}\text { Regra } \\
1 \\
\end{array}$ & $\begin{array}{l}\text { Faixa } 1 \\
0-25 \% \\
\end{array}$ & $\begin{array}{c}\text { Faixa } 2 \\
25 \%-55 \%\end{array}$ & $\begin{array}{c}\text { Faixa } 3 \\
55 \%-70 \% \\
\end{array}$ & $\begin{array}{c}\text { Faixa } 4 \\
70 \%-100 \%\end{array}$ \\
\hline RMSP & $21.60^{*}$ & 29.50 & 30.80 & 33.00 \\
\hline Buenópolis & 2.40 & 2.40 & 2.50 & 2.50 \\
\hline Valinhos & 7.40 * & 10.20 & 14.20 & 15.00 \\
\hline $\begin{array}{c}\text { Regra } \\
2\end{array}$ & $\begin{array}{l}\text { Faixa } 1 \\
0-15 \%\end{array}$ & $\begin{array}{c}\text { Faixa } 2 \\
15 \%-30 \%\end{array}$ & $\begin{array}{c}\text { Faixa } 3 \\
30 \%-60 \%\end{array}$ & $\begin{array}{c}\text { Faixa } 4 \\
60 \%-100 \%\end{array}$ \\
\hline RMSP & 20.40 * & $29.70^{*}$ & 31.30 & 33.00 \\
\hline Buenópolis & 2.40 & 2.50 & 2.50 & 2.50 \\
\hline Valinhos & 7.60 * & 11.00 * & 13.50 & 15.00 \\
\hline
\end{tabular}

\begin{tabular}{|c|c|c|c|c|c|}
\hline $\begin{array}{c}\text { Regra } \\
3\end{array}$ & $\begin{array}{l}\text { Faixa } 1 \\
0-15 \%\end{array}$ & $\begin{array}{c}\text { Faixa } 2 \\
15 \%-30 \%\end{array}$ & $\begin{array}{c}\text { Faixa } 3 \\
30 \%-50 \%\end{array}$ & $\begin{array}{c}\text { Faixa } 4 \\
50 \%-60 \%\end{array}$ & $\begin{array}{c}\text { Faixa } 5 \\
60 \%-100 \%\end{array}$ \\
\hline RMSP & 18.50 * & $28.40^{*}$ & 30.50 * & 31.60 * & $33.00 *$ \\
\hline Buenópolis & 2.40 & 2.50 & 2.50 & 2.50 & 2.50 \\
\hline Valinhos & 6.90 * & 9.00 * & 10.40 * & 12.30 * & 14.90 * \\
\hline $\begin{array}{c}\text { Regra } \\
4\end{array}$ & $\begin{array}{l}\text { Faixa } 1 \\
0-20 \% \\
\end{array}$ & $\begin{array}{c}\text { Faixa } 2 \\
20 \%-30 \%\end{array}$ & $\begin{array}{c}\text { Faixa } 3 \\
30 \%-40 \%\end{array}$ & $\begin{array}{c}\text { Faixa } 4 \\
40 \%-60 \%\end{array}$ & $\begin{array}{r}\text { Faixa } 5 \\
60-100 \%\end{array}$ \\
\hline RMSP & 20.30 * & 28.00 * & 29.80 * & 30.90 * & 32.90 * \\
\hline Buenópolis & 2.40 & 2.40 & 2.50 & 2.50 & 2.50 \\
\hline Valinhos & 6.30 * & 8.00 * & 9.80 * & 12.90 * & 15.00 \\
\hline
\end{tabular}

Os resultados indicam em quais faixas operativas ocorreram falhas no atendimento integral dos valores requeridos pelas demandas. O ponto de controle em Buenópolis teve como fornecimento médio praticamente o valor integral da demanda requerida para todas as regras. 
$\mathrm{O}$ atendimento à RMSP e a Valinhos apresentou valores médios menores do que os requeridos, em algumas das regras operativas. Para a Regra 1 os fornecimentos médios foram menores do que os requeridos apenas na faixa 1. Para a Regra 2 os fornecimentos médios foram menores do que os requeridos nas faixas 1 e 2. As regras 3 e 4 apresentaram em geral, valores médios fornecidos menores do que os valores requeridos em todas as faixas de operação.

$\mathrm{Na}$ Tabela 6.12 são mostrados os resultados comparativos das regras com relação aos déficits de atendimento às demandas.

Tabela 6.12 - Resultados comparativos das regras operativas em termos dos déficits de atendimento às demandas.

\begin{tabular}{c|c|c|c|c}
\hline \multicolumn{6}{c}{ № de meses totais com déficits de atendimento às demandas } \\
\hline & Regra 1 & Regra 2 & Regra 3 & Regra 4 \\
\hline RMSP & 10 & 11 & 11 & 10 \\
\hline Buenópolis & 1 & 1 & - & - \\
\hline Valinhos & 6 & 10 & 10 & 15 \\
\hline \multicolumn{6}{c}{} \\
\hline Maior número de meses consecutivos com déficits no atendimento às demandas \\
\hline \multicolumn{7}{r}{} & Regra 1 & Regra 2 & Regra 3 & Regra 4 \\
\hline RMSP & 6 & 6 & 6 & 6 \\
\hline Buenópolis & 1 & 1 & - & - \\
\hline Valinhos & 3 & 4 & 4 & 6 \\
\hline
\end{tabular}

Com relação ao maior número de meses consecutivos com déficits de atendimento à RMSP, todas as regras apresentaram falhas durante 6 meses seguidos entre junho e novembro de 2015. Com relação à Valinhos, todas as regras obtiveram as maiores falhas consecutivas de fornecimento entre meados de 2014, e as regras 1 e 3 também apresentaram 3 meses consecutivos de falhas entre os meses de junho e agosto de 2015 . 


\section{CONCLUSÕES}

A metodologia apresentada neste estudo forneceu informações relevantes para possibilitar a definição de regras operativas em reservatórios. Em particular, foi possível obter para o Sistema Cantareira, regras operativas análogas a atualmente vigente pela resolução conjunta ANA/DAEE no 925 de 2017.

O modelo de otimização por PD foi capaz de representar convenientemente o problema de otimização para a análise prática do período crítico. O software CSUDP, empregado para a solução do problema multidimensional, apresentou rápida convergência para os resultados ótimos devido ao uso combinado das técnicas de DPSA e IDP. Devido ao caráter determinístico, o modelo tende a fornecer menores valores de vazão as demandas a fim de economizar água, podendo atende-las com alta eficiência durante os períodos de baixas afluências.

A metodologia apresentada para a formulação das redes neurais mostrou sua versatilidade para reconhecimento e mapeamento de padrões complexos, mesmo com seu cálculo por meio do solver padrão do Microsoft Excel. As redes A e B apresentaram alta correspondência com os conjuntos de dados observados, com coeficientes de soma quadrática das diferenças variando de 0,83 a 0,92 para a Rede A, e com valor de 0,99 para a Rede B.

A estratégia utilizada para obter as regras de operação resultou em quatro regras operativas com configurações distintas para análise do SC a longo prazo. $\mathrm{O}$ modelo AcquaNet foi utilizado a fim de comparar seus desempenhos para a série histórica. A definição de valores de demanda requeridos por faixas de operação tem efeitos positivos e negativos sobre o desempenho do sistema a longo prazo. Em geral, menores valores de vazões requeridas resultam em maior preservação do volume útil, porém, é de interesse para a gestão obter alta eficiência nas retiradas para as demandas.

Em particular, a Regra 4, foi formulada com as faixas de operação da regra atual vigente no SC. Porém, os valores de demanda requeridos pela regra atual são mais conservadores do que os valores obtidos pela metodologia deste estudo. Em termos dos atendimentos à demanda da RMSP, a Regra 4 e a regra vigente apresentaram vazões de $33 \mathrm{~m} 3 / \mathrm{s}$ durante $84 \%$ do período. No entanto, a regra vigente 
mostrou-se mais eficiente em termos da conservação dos volumes acumulados no reservatório, por apresentar valores de demanda mais conservadores do que a Regra 4 nas faixas de operação intermediárias (Faixas 2 e 3).

Os efeitos destas diferenças são visíveis na permanência de volumes ao longo da série histórica. A regra vigente tem como efeito possível a conservação do volume útil em faixas de operação menos restritas. Em contrapartida, as faixas operativas intermediárias (faixas 2 e 3 ) apresentam valores de demandas requeridas menores do que os valores praticados pela regra 4 .

As regras obtidas tiveram seus resultados de volume e atendimentos às demandas comparados. Dentre as regras de operação obtidas, a Regra 1 obteve 0 melhor desempenho com relação ao atendimento às demandas, fornecendo vazões de $2,5 \mathrm{~m}^{3} / \mathrm{s}$ com $96 \%$ de garantia para Buenópolis, $15 \mathrm{~m} 3 / \mathrm{s}$ com $80 \%$ de garantia para Valinhos, e $33 \mathrm{~m} 3 / \mathrm{s}$ com $80 \%$ de garantia para a RMSP. Comparada às demais regras de operação, a Regra 1 foi a que obteve menores falhas no atendimento às demandas durante o período simulado, de 1930 a 2017.

O ajuste das faixas de operação e das demandas requeridas oferecem vantagens e desvantagens no desempenho do reservatório ao longo da série histórica. A metodologia apresentada pode contribuir para as análises destes aspectos, considerando as complexidades destes sistemas. 


\section{REFERÊNCIAS BIBLIOGRÁFICAS}

ALE, S.; BOWLING, L. C.; OWENS, P. R.; BROUDER, S. M.; FRANKENBERGER, J. R. Development and application of a distributed modeling approach to assess the watershed-scale impact of drainage water management. Agricultural Water Management, v. 107, 2012, p. 23-33.

ANA - AGÊNCIA NACIONAL DE ÁGUAS; MINISTÉRIO DO MEIO AMBIENTE. Atlas Brasil Abastecimento Urbano de Água - Volume 2. Resultados por Estado. Brasília, 2010. Disponível em: <http://atlas.ana.gov.br/Atlas/downloads/atlas/Resumo\%20Executivo/Atlas\%20Brasil\% 20-\%20Volume\%202\%20-\%20Resultados\%20por\%20Estado.pdf >. Acesso em: 10 set. 2016.

ANA - Agência Nacional de Águas. Conjuntura dos recursos hídricos no Brasil - Encarte especial sobre a Crise Hídrica. 2014. Disponível em: < http://www3.snirh.gov.br/portal/snirh/centrais-de-conteudos/conjuntura-dos-recursoshidricos/crisehidrica2014.pdf>. Acesso em 10 de agosto de 2016.

ANDREU, J.; CAPILLA, J.; SANCHIS, E. AQUATOOL, a generalized decision-support system for water-resources planning and operational management. Journal of Hydrology $v$. 177, n. 3-4, p. 269-291, abr. 1996.

ANA - Agência Nacional de Águas; DAEE - Departamento de Águas e Energia Elétrica. Resolução conjunta ANA/DAEE no335, de 05 de março de 2014. Disponível em: $<$ http://www.daee.sp.gov.br/images/documentos/resoluca03352014.pdf $>$. Acesso em 10 de agosto de 2017.

Resolução conjunta ANA/DAEE №925, de 29 de maio de 2017. Disponível em: <http://www.sspci.org.br/images/downloads/RESOLUCAO 926-2017.pdf>. Acesso em 02 de março de 2018.

Resolução conjunta ANA/DAEE №926, de 29 de maio de 2017. Dispõe sobre as condições de operação para o Sistema Cantareira - SC, delimitado, para os fins desta Resolução, como o conjunto dos reservatórios Jaguari-Jacareí, Cachoeira, Atibainha e Paiva Castro.

Disponível em: <http://arquivos.ana.gov.br/resolucoes/2017/925-2017.pdf $>$. Acesso em 02 de março de 2018.

BELLMAN, R. Dynamic Programming. New Jersey: Princeton University Press, 1957. 
BRAGA, B.B.F.J. et al. Stochastic optimization of multiple-reservoir-system operation. Journal of Water Resources Planning and Management, v. 117, n. 3, p. 471-481, jul. 1991. CANCELLIERE, A. et al. A Neural Networks Approach for Deriving Irrigation Reservoir Operating Rules. Water Resources Management. v. 16, n. 1, p.71-88, feb. 2002.

CHANDRAMOULI, V.; DEKA, P. Neural Network Based Decision Support Model for Optimal Reservoir Operation. Water Resources Management, v.19, p. 447-464, 2005.

FAYAED, S.S.; EL-SHAFIE, A.; JAAFAR, O. Reservoir-system simulation and optimization techniques. Stochastic Environmental Research and Risk Assessment, v. 27, n. 7, p. 1751-1772, 2013.

GOES, A. Análise Dinâmica de Riscos, Uma Hiper-heurística Híbrida para Apoio à Decisão na Operação de Reservatórios. Revista Brasileira de Recursos Hídricos, v. 18, n. 3, p. 53-67, 2013.

GOVINDARAJU, R.S.; RAO, A.R. Introduction. In: GOVINDARAJU, R.S.; RAO, A.R. (Orgs). Artificial Neural Networks in Hydrology. Springer Netherlands, 2000.

HAYKIN, S.O. Neural Networks and learning machines. 3 ed. New Jersey: Pearson, 2008. HARMEL, R.D.; SMITH, P.K. Consideration of measurement uncertainty in the evaluation of goodness-of-fit. Journal of Hydrology, v. 337, 2007, p. 326-336.

JAIN, S.K., SENTHIL-KUMAR, A.R., AGARWAL, P.K. Application of Artificial Neural Networks (ANN) in reservoir operation. National Institute of Hydrology, India. 2000.

Disponível em <http://www.indiawaterportal.org/articles/application-artificial-neuralnetworks-reservoir-operation-research-report-national> Acesso em 15/05/2018.

KARAMOUZ, M.; HOUCK, M.H. Comparison of stochastic and deterministic dynamic programming for reservoir operating rule generation. Journal of the American Water Resources Association, v. 23, n. 1, p. 1-9, fev. 1987.

KARAMOUZ, M.; VASILIADIS, H.V. Bayesian Stochastic Optimization of Reservoir Operation.

Water Resources Research, v. 28, n. 5, p. 1221-1232, maio 1992.

KARAMOUZ, M.; SZIDAROVSZKY, F.; ZAHRAIE, B. Water Resources Systems Analysis. 1. ed. CRC Press, 2003.

LABADIE, J.W. Optimal Operation of Multireservoir Systems: State-of-the-Art Review. Journal of Water Resources Planning and Management, v. 130, n. 2, p. 93-111, mar. 2004. LABADIE, J.W. MODSIM 8.1: River Basin Management Decision Support System - User Manual and Documentation. 2010. Disponível em: <http://modsim.engr.colostate.edu/modsim.php>. Acesso em: 16 dez. 2016.

LABSID - Laboratório de Sistemas de Suporte a Decisões (USP). AcquaNet - Manual do AcquaNet 2013. 12 ago. 2015. Disponível em: $<$ http://www.labsid.eng.br/software/ManualAcquaNet2013.pdf $>$. Acesso em: 10 jan. 2017. 
LANNA, A.E.L. Introdução. In: PORTO, R. L. et al. Técnicas Quantitativas para o Gerenciamento de Recursos Hídricos. 2. ed. Porto Alegre: Ed. Universidade/ UFRGS/Associação Brasileira de Recursos Hídricos, 1997. p. 15-41.

LOUCKS, D.P. et al. Water Resources Systems Planning and Management - An Introduction to Methods, Models and Applications. Paris: UNESCO, 2005.

McCulloch, W.S.; Pitts, W. A logical calculus of the ideas immanent in nervous activity. The bulletin of mathematical biophysics. v. 5, n. 4, p. 115-133, dec. 1943.

MELLO Jr, A.V.; MATOS, L. N. Otimização da operação de reservatório pela Programação Dinâmica em um processo de decisão markoviano. RBRH - Revista Brasileira de Recursos Hídricos, v. 4, n. 3, p. 5-15, jul. 1999.

NANDALAL, K.D.W.; BOGARDI, J.J. Dynamic Programming Based Operation of

Reservoirs - Application and Limits. United States: Cambridge University Press, 2007. PORTO, R.L. et al. Técnicas Quantitativas para o Gerenciamento de Recursos Hídricos. 2. ed. Porto Alegre: Ed. Universidade/UFRGS/Associação Brasileira de Recursos Hídricos, 1997.

PORTO, R.L.; AZEVEDO, L.G.T. Sistemas de Suporte a Decisões Aplicados a Problemas de Recursos Hídricos. In: Técnicas Quantitativas para o Gerenciamento de Recursos Hídricos. 2. ed. Porto Alegre: Ed. Universidade/UFRGS/Associação Brasileira de Recursos Hídricos, 1997. p. 43-95.

PORTO, R. L. L. et al. Sistema de suporte a decisão para análise de sistemas de recursos hídricos, In: SILVA, R. C. V.; et al. Métodos Numéricos em Recursos Hídricos 6 . Porto Alegre - RS. ABRH/UFRGS, 2003, Cap. 4. p. 93 - 240.

PORTO, R.L. et al. AcquaNet: Arquitetura, estratégias e ferramentas. In: XVI SIMPÓSIO BRASILEIRO DE RECURSOS HÍDRICOS. João Pessoa: 2005.

RANI, D.; MOREIRA, M.M. Simulation-Optimization Modeling: A Survey and Potential

Application in Reservoir Systems Operation. Water Resources Management, v. 24, n. 6, p. 1107-1138, abr. 2010.

RAMAN, H.; CHANDRAMOULI, V. Deriving a general operating policy for reservoirs using Neural network. Journal of Water Resources Planning and Management, v. 122, n. 5, p. 342-347, set. 1996.

ROBERTO, A.N. et al. O Novo Sistema de Suporte a Decisões AcquaNet. In: XVII SIMPÓSIO BRASILEIRO DE RECURSOS HÍDRICOS. São Paulo: 2007.

SABESP - Companhia de Saneamento Básico do Estado de São Paulo. Região Metropolitana de São Paulo. Disponível em < http://site.sabesp.com.br/site/interna/Default.aspx?secaold=31> . Acesso em $10 \mathrm{de}$ agosto de 2018. 
SABESP - Companhia de Saneamento Básico do Estado de São Paulo. CHESS - Crise Hídrica, Estratégia e Soluções da Sabesp. 30 abr. 2015a. Disponível em: < http://site.sabesp.com.br/site/uploads/file/crisehidrica/chess crise hidrica.pdf>. Acesso em 10 de agosto de 2016.

SABESP - COMPANHIA DE SANEAMENTO BÁSICO DO ESTADO DE SÃO PAULO.

Proposta renovação outorga Sistema Cantareira., 30 jul. 2015b. Disponível em: < http://arquivos.ana.gov.br/institucional/sof/Renovacao Outorga/SABESP\%20-

\%20Proposta\%20de\%20Renova\%C3\%A7\%C3\%A30\%200utorga\%20do\%20Sistema

\%20Cantareira.pdf >. Acesso em 10 de agosto de 2016.

Sabesp começa obras para captar volume morto de reservatório. G1 São Paulo, Globo,

Disponível em: <http://g1.globo.com/sao-paulo/noticia/2014/03/sabesp-comeca-obraspara-captar-volume-morto-de-reservatorio.html>. Acesso em: 12 dez. 2016.

SALAS, J.D.; MARKUS, M. e TOKAR A.S. Streamflow forecasting based on artificial neural networks. In: GOVINDARAJU, R.S.; RAO, A.R. (Orgs). Artificial Neural Networks in Hydrology. Springer Netherlands, 2000.

SCHARDONG, A. Aplicação das técnicas de Programação Linear e extensões para otimização de Água em Sistemas de Recursos Hídricos utilizando métodos de Pontos Interiores. Dissertação (Mestrado em Engenharia Hidráulica e Saneamento) São Paulo: Departamento de Engenharia Hidráulica e Sanitária , Escola Politécnica USP, 2006.

SIMONOVIC, S.P. Reservoir systems analysis: closing gap between theory and practice. Journal of Water Resources Planning and Management, v. 118, n. 3, p. 262-280, 1992.

SIMONOVIC, S.P. Managing Water Resources - Methods and Tools for a Systems Approach. Paris: UNESCO, 2009.

STEDINGER, J.R.; SULE, B.F.; LOUCKS, D.P. Stochastic Dynamic Programming Models for Reservoir Operation Optimization. Water Resources Research, v. 20, n. 11, p. 14991505, 1984.

TURGEON, A. Incremental dynamic programing may yield nonoptimal solutions. Water

Resources Research, v. 18, n. 6, p. 1599-1604, dez. 1982.

WHATELY. M.; CUNHA. P. CANTAREIRA 2006 - Um olhar sobre o maior manancial de água da Região Metropolitana de São Paulo. São Paulo: Instituto Socioambiental, 2007. Disponível em: <http://www.socioambiental.org/banco imagens/pdfs/10289.pdf>. Acesso em 11 de novembro de 2016.

WURBS, R.A. Reservoir-system simulation and optimization models. Journal of Water Resources Planning and Management, v. 119, n. 4, p. 455-472, 1993. 
YAKOWITZ, S. Dynamic Programming Applications in Water Resources. Water Resources Research, v. 18, n. 4, p. 673-696, 1982.

YEH, W.G.W. Reservoir management and operation models: a state-of-the-art Review. Water Resources Research, v. 21, n. 12, p. 1797-1818, 1985.

ZUFFO, A.C. Análise Multicriterial ao planejamento de Recursos Hídricos: Uma metodologia Fuzzy para o enfoque ambiental. Tese de Livre Docência-Campinas: UNICAMP, 2010. 